

\section{PODSTAWY INŻYNIERII ŚRODOWISKA}


盗 


\section{PODSTAWY INŻYNIERII ŚRODOWISKA}

Danuta Lipińska 
Danuta Lipińska - Uniwersytet Łódzki, Wydział Ekonomiczno-Socjologiczny Katedra Gospodarki Światowej i Integracji Europejskiej

90-214 Łódź, ul. Rewolucji 1905 roku nr 41/43

\author{
RECENZENT \\ Jerzy Jeznach \\ REDAKTOR INICJUJĄCY \\ Iwona Gos \\ OPRACOWANIE REDAKCYJNE \\ AGENT PR \\ SKŁAD KOMPUTEROWY \\ AGENT PR \\ PROJEKT OKŁADKI \\ Stämpfli Polska Sp. z o.o.
}

Zdjęcie wykorzystane na okładce: (c) Shutterstock.com

Publikacja została przygotowana w ramach projektu „Utworzenie nowych interdyscyplinarnych programów kształcenia w zakresie ekonomii ochrony środowiska

(w języku polskim i angielskim) w Uniwersytecie Łódzkim" współfinansowanego ze środków funduszy norweskich i krajowych

(Nr umowy FSS/2014/HEI/W/0124/U/0014)

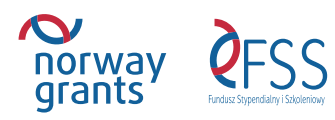

(C) Copyright by Danuta Lipińska, Łódź 2016

(C) Copyright for this edition by Uniwersytet Łódzki, Łódź 2016

Wyłączną odpowiedzialność za treść podręcznika ponosi autorka

Podręcznik nie jest przeznaczony do sprzedaży

Wydane przez Wydawnictwo Uniwersytetu Łódzkiego

Wydanie I. W.07221.15.0.S

Ark. wyd. 8,4; ark. druk. 9,625

ISBN 978-83-7969-964-3

e-ISBN 978-83-7969-970-4

Wydawnictwo Uniwersytetu Łódzkiego

90-131 Łódź, ul. Lindleya 8

www.wydawnictwo.uni.lodz.pl

e-mail: ksiegarnia@uni.lodz.pl

tel. (42) 6655863 


\section{SPIS TREŚCI}

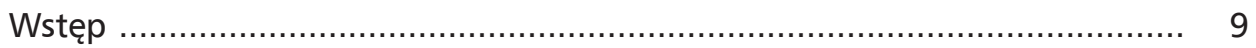

Rozdział 1. Inżynieria środowiska jako dyscyplina naukowa ................ 13

1.1. Pojęcie i przedmiot inżynierii środowiska ................................... 13

1.2. Interdyscyplinarność inżynierii środowiska ............................... 14

1.3. Inżynieria ekologiczna ....................................................... 16

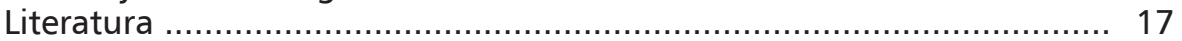

Rozdział 2. Wybrane procesy w inżynierii środowiska ......................... 18

2.1. Wprowadzenie ................................................................... 18

2.2. Klasyfikacja procesów ............................................................. 19

2.3. Ogólna charakterystyka wybranych procesów ............................. 20

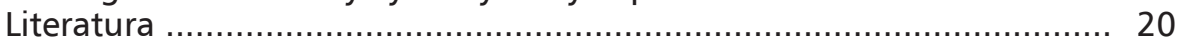

Rozdział 3. Techniki membranowe .................................................... 27

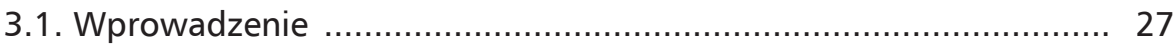

3.2. Istota technik membranowych ............................................... 28

3.3. Membrany ....................................................................... 29

3.4. Charakterystyka wybranych technik membranowych ................... 30

3.5. Zastosowanie technik membranowych w gospodarce .................. 32

Literatura .............................................................................. 35

Rozdział 4. Technologie środowiskowe ............................................ 37

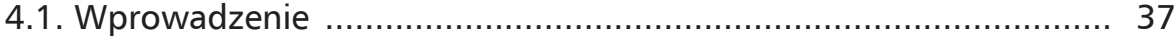

4.2. Istota technologii środowiskowych ....................................... 37

4.3. Strategie i działania w zakresie technologii środowiskowych ......... 38

4.4. System weryfikacji technologii środowiskowych ......................... 42

4.5. Obszary zastosowania technologii środowiskowych ..................... 44

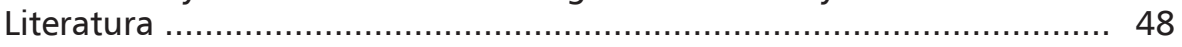

Rozdział 5. Innowacyjne technologie środowiskowe. Ekoinnowacje technologiczne 50

5.1. Pojęcia wprowadzające ……….......................................... 50

5.2. Produkcja biogazu ............................................................. 51

5.3. Bezwykopowe technologie budowy i odnowy rurociągów ............. 54

5.4. Ekoinnowacje technologiczne .............................................. 57

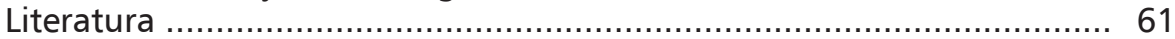


Rozdział 6. Obiekty budowlane służące ochronie środowiska ............... 63

6.1. Wprowadzenie ................................................................ 63

6.2. Obiekty budowlane mające znaczenie dla ochrony środowiska ...... 64

6.3. Budownictwo ekologiczne .................................................. 66

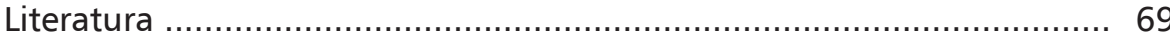

Rozdział 7. Inżynieria środowiska w służbie ochrony powietrza. Procesy oczyszczania gazów odlotowych ….......................................... 70

7.1. Źródła i rodzaje zanieczyszczeń powietrza ................................. 70

7.2. Działania o charakterze inżynieryjnym w ochronie powietrza ......... 71

7.3. Główne metody oczyszczania gazów odlotowych ....................... 73

7.4. Urządzenia oczyszczające ……………….............................. 76

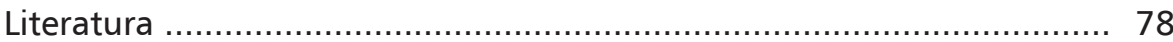

Rozdział 8. Inżynieria środowiska a ochrona litosfery. Rekultywacja gleb 80

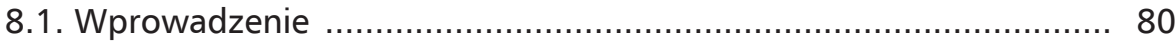

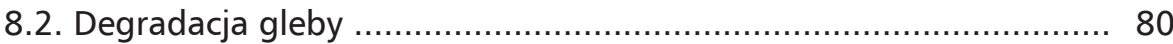

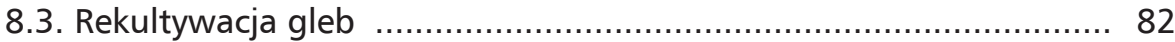

8.4. Technologie przeróbki odpadów komunalnych ............................ 89

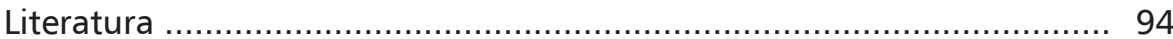

Rozdział 9. Ujęcia wód. Uzdatnianie wody ............................................. 96

9.1. Ujęcia wód jako budowle wodne ............................................. 96

9.2. Metody uzdatniania wody ................................................... 98

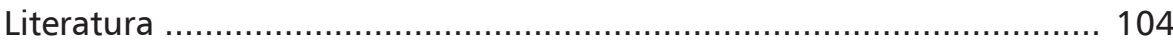

Rozdział 10. Systemy wodociągowe i kanalizacyjne ............................. 105

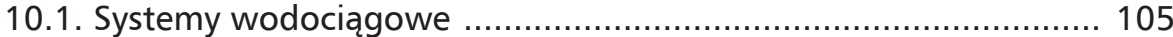

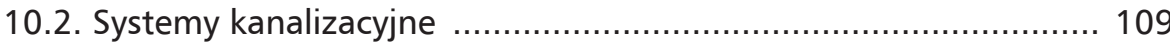

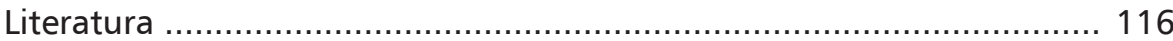

Rozdział 11. Inżynieria środowiska w ochronie wód. Technologie oczyszczania ścieków

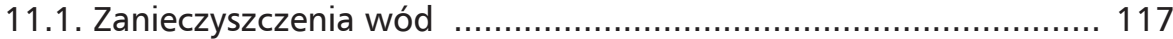

11.2. Ochrona wód. Rekultywacja i renaturyzacja .............................. 118

11.3. Rodzaje ścieków ................................................................... 123

11.4. Rodzaje oczyszczalni ścieków .............................................. 125

11.5. Oczyszczanie ścieków na terenach niezurbanizowanych ............. 135

11.6. Metody przeróbki osadów ściekowych ...................................... 137

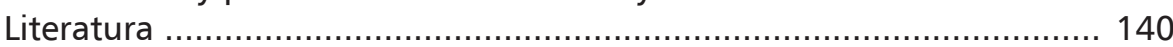


Rozdział 12. Inżynieria środowiska a sektor energetyki 143

12.1. Technologie środowiskowe w energetyce 143

12.2. Inżynieria środowiska a energetyka konwencjonalna 145

12.3. Inżynieria środowiska na rzecz gospodarki niskoemisyjnej 148

Literatura 150

Spis rysunków 152

Spis tabel 153 



\section{Wstęp}

Zagadnienia, którymi zajmuje się inżynieria środowiska, od wielu lat stanowią przedmiot zainteresowania nie tylko inżynierów, ale i ekonomistów w wielu krajach świata. Tematem badań naukowych oraz analiz gospodarczych staje się coraz częściej kwestia wykorzystania zasobów naturalnych i ich ochrona poprzez stosowanie inżynieryjnych rozwiązań dla zrównoważonego wzrostu gospodarczego.

Inżynieria środowiska to wyjątkowa dziedzina nauk technicznych - ważna zarówno z perspektywy jednostki, jak i zbiorowości - wpływająca na długość i jakość życia człowieka oraz gospodarkę każdego kraju. Ma bardzo duże znaczenie w rozwoju innowacyjnych technologii, m.in. w ochronie wód, gleb i powietrza, w zmniejszeniu zużycia energii, a także ilości składowanych odpadów. Praktyczne działania, które są konsekwencją rozwoju inżynierii środowiska, przyczyniają się do postępu w sferze gospodarki i życia społecznego z poszanowaniem środowiska naturalnego, przede wszystkim poprzez wdrożenie rozwiązań technicznych zgodnych z zasadami zrównoważonego rozwoju i zarządzanie nimi. Istotne jest także to, że inżynieria środowiska jest nauką interdyscyplinarną, bowiem na podstawie praw nauk technicznych, przyrodniczych i społecznych są stosowane metody inżynierskie w wielu obszarach i sektorach działalności gospodarczej, na przykład w zaopatrzeniu w wodę, odprowadzaniu ścieków, unieszkodliwianiu odpadów, energetyce czy też w budownictwie. Wiele aktualnych zadań w zakresie zielonych sektorów gospodarki realizowanych jest przez specjalistów w dziedzinie inżynierii środowiska, jednakże coraz bardziej dostrzega się potrzebę posiadania przez nich wiedzy i umiejętności z dziedziny nauk ekonomicznych.

Istnienie silnych interakcji pomiędzy gospodarką, środowiskiem oraz technologiami i metodami inżynieryjnymi stosowanymi w celu kształtowania i ochrony środowiska naturalnego sprawia, że konieczne jest uwzględnienie problematyki inżynierii środowiska również w programach kształcenia studentów ekonomii, ukierunkowanych w szczególny sposób na aspekty ekonomiczne ochrony środowiska.

Niniejszy podręcznik obejmuje szeroko rozumiane podstawy inżynierii środowiska. Zamierzeniem autorki było przystępne przedstawienie niezbędnego i najbardziej aktualnego kompendium wiedzy z tego obszaru. 
Dobór omawianych zagadnień ma charakter subiektywny, nakierowany jest jednak na osiągnięcie jak najlepszych celów dydaktycznych i zdobycie najistotniejszych informacji z dziedziny stanowiącej przedmiot niniejszego opracowania.

Układ książki jest następujący. W rozdziale pierwszym omówiono pojęcie inżynierii środowiska, zaprezentowano cele, zadania i kierunki badań, a także zagadnienie interdyscyplinarności tej dyscypliny naukowej. Ostatnia część tego rozdziału poświęcona jest inżynierii ekologicznej.

W rozdziale drugim dokonano przeglądu i charakterystyki głównych procesów mechanicznych, fizycznych i chemicznych stosowanych w inżynierii środowiska. Przedstawiono krótko istotę każdego procesu, jego rolę $w$ rozdzielaniu mieszanin oraz sposoby wykorzystania.

W kolejnym rozdziale zaprezentowano istotę pojęcia technik membranowych oraz przybliżono cechy membran stosowanych w tych technikach. W ramach charakterystyki wybranych najważniejszych technik membranowych zwrócono szczególną uwagę na zasadę ich działania w procesie separacji. Istotną część tego rozdziału stanowi omówienie sposobów zastosowania technik membranowych w różnych sektorach i branżach gospodarki.

Rozdział czwarty obejmuje zagadnienia związane z technologiami środowiskowymi. Po wyjaśnieniu istoty tych technologii przywołano podejmowane w Unii Europejskiej oraz w Polsce działania i inicjatywy wspierające ich rozwój w ostatnich latach. W szerszym zakresie przedstawiono system weryfikacji technologii środowiskowych jako szczególnie istotną formę wsparcia technologicznej innowacyjności. W ostatniej części rozdziału dokonano przeglądu obszarów i dziedzin działalności człowieka, w których mają zastosowanie technologie proekologiczne.

Rozdział piąty stanowi rozwinięcie rozdziału poprzedniego i poświęcony jest charakterystyce wybranych technologii prośrodowiskowych, które są obecnie proponowane w ramach inżynierii i ochrony środowiska. Podano w nim definicje kluczowych wstępnych pojęć oraz przedstawiono kierunki rozwoju nowych technologii w różnych dziedzinach gospodarki. Kolejne dwie części rozdziału prezentują technologię produkcji biogazu oraz bezwykopowe technologie budowy i odnowy rurociągów. Rozdział kończą rozważania na temat technologicznych ekoinnowacji.

Rozważania w rozdziale szóstym rozpoczęto od wyjaśnienia podstawowych pojęć związanych z budownictwem, a następnie szczegółowo omówiono obiekty budowlane istotne w ochronie środowiska, odnosząc się do wybranych dziedzin gospodarki. Podjęto w nim również tematykę budownictwa ekologicznego, wskazując cechy tego typu budownictwa oraz stosowane w nim rozwiązania inżynieryjne. 
Rozdział siódmy poświęcony został inżynieryjnym podstawom ochrony powietrza. Na wstępie dokonano przeglądu źródeł zanieczyszczeń i usystematyzowano ich rodzaje. Następnie zostały przybliżone działania techniczne podejmowane w celu ochrony powietrza. W dalszej części rozdziału zaprezentowano główne metody oczyszczania gazów odlotowych oraz omówiono wybrane urządzenia oczyszczające stosowane w ochronie powietrza.

Problematyka ochrony gleb z punktu widzenia inżynierii środowiska została przedstawiona w rozdziale ósmym niniejszego podręcznika. Po wyjaśnieniu istoty pojęcia degradacji gleby $\mathrm{i}$ jej form w dalszej części rozdziału skupiono się na rekultywacji gleb - podstawowym działaniu ochronnym i naprawczym stosowanym w celu ochrony gleby. Szczególną uwagę poświęcono charakterystyce poszczególnych metod rekultywacji. W ostatniej części rozdziału opisano główne metody gospodarowania odpadami w kontekście wykorzystywanych technologii i zrównoważonego rozwoju.

W kolejnych trzech rozdziałach podręcznika podjęto rozważania na temat inżynierii wodno-ściekowej. Pierwsza część rozdziału dziewiątego poświęcona jest ujęciom wód - ich klasyfikacji i charakterystyce. Dalsza część przedstawia metody uzdatniania wody pobranej z tych ujęć. Po przedstawieniu klasyfikacji scharakteryzowano szerzej wybrane metody i procesy uzdatniania i odnowy wody.

Kontynuację tematyki wodnej stanowi rozdział dziesiąty, który przedstawia klasyfikację oraz charakterystykę systemów wodociągowych oraz kanalizacyjnych. Rozdział jedenasty natomiast podejmuje tematykę zanieczyszczeń wód, uwzględniając metody ochrony tych wód. Szczególną uwagę zwrócono w tym względzie na dwie metody proponowane przez inżynierię środowiska - rekultywację i renaturyzację wód. Ścieki stanowią istotne źródło zanieczyszczeń wód, dlatego w dalszych częściach tego rozdziału pojawia się problematyka oczyszczania ścieków. Opisano rodzaje ścieków oraz technologie ich oczyszczania wraz z charakterystyką niektórych procesów zachodzących w poszczególnych oczyszczalniach. Ponadto zaprezentowano występujące w literaturze przedmiotu technologie oczyszczania ścieków na terenach niezurbanizowanych. W ostatniej części rozdziału przedstawiono wybrane metody przeróbki osadów ściekowych.

Podręcznik kończy rozdział poświęcony technologiom środowiskowym i innowacyjnym rozwiązaniom inżynieryjnym w sektorze energetyki, w tym także opartej na węglu. Zwrócono też uwagę na działania podejmowane $w$ ramach inżynierii środowiska na rzecz wdrażania koncepcji gospodarki niskoemisyjnej. 
Podręcznik adresowany jest do szerokiej grupy czytelników, w szczególności do studentów wyższych uczelni ekonomicznych na kierunku ekonomia ekobiznes lub ekonomia ochrony środowiska. Obecnie na rynku brak opracowań podejmujących tematykę inżynierii środowiska i skierowanych do przyszłych ekonomistów, w związku z tym jedną z przesłanek przygotowania niniejszej publikacji była chęć wypełnienia tej luki. Podręcznik może być również wykorzystywany przez studentów na kierunkach przyrodniczych.

Zaprezentowane tutaj informacje nie wyczerpują wszystkich zagadnień, którymi zajmuje się inżynieria środowiska. Pozwalają jednak na uzyskanie ogólnej wiedzy na temat podstawowych procesów, technik, technologii, programów oraz metod proponowanych przez tę dyscyplinę naukową dla zrównoważonego wzrostu społeczno-gospodarczego społeczeństw.

Autorka opracowania jest świadoma tego, że nie jest ono kompletne, ponieważ obszar badań i problemów, jaki obejmuje inżynieria środowiska, jest bardzo szeroki, a każdy z zamieszczonych poniżej rozdziałów zasługuje na rozszerzenie do rozmiarów osobnej publikacji. Książka ta może jednak stanowić dobry wstęp do zdobycia podstawowej wiedzy inżynieryjnej w zakresie kształtowania i ochrony środowiska dla osób nieposiadających wykształcenia w tej dziedzinie, a zainteresowanych problematyką inżynieryjnych aspektów rozwoju gospodarczego z poszanowaniem środowiska naturalnego. Przy czym na rynku dostępnych jest wiele pozycji naukowych, zarówno w języku polskim, jak i anglojęzycznych, prezentujących w sposób bardziej zaawansowany zagadnienia w obszarze inżynierii środowiska. Autorka wyraża zatem nadzieję, że niniejszy podręcznik zachęci czytelników do samodzielnych przemyśleń nad zawartymi w nim treściami i stanie się inspiracją do dalszego ich zgłębiania. Problematyka inżynierii środowiska jest bowiem bardzo szeroka i w wielu wypadkach dyskusyjna. Poza tym należy podkreślić, że wiedza w zakresie inżynierii środowiska wymaga stałej aktualizacji ze względu na szybko rozwijające się w skali globalnej technologie i innowacje ekologiczne, wykorzystujące wiedzę inżynieryjną w zakresie kształtowania i ochrony środowiska zgodnie z zasadami zrównoważonego rozwoju.

Recenzentowi, Panu prof. dr. hab. inż. Jerzemu Jeznachowi składam serdeczne podziękowania za rzeczową i życzliwą recenzję oraz za cenne uwagi, które przyczyniły się do ostatecznego kształtu niniejszego podręcznika. 


\section{Rozdział 1}

\section{Inżynieria środowiska jako dyscyplina naukowa}

\subsection{Pojęcie i przedmiot inżynierii środowiska}

Od wielu lat do praktyki gospodarczej w skali globalnej wdrażane są idee zrównoważonego rozwoju. Proces ten wymaga między innymi umiejętnego połączenia wiedzy technicznej i przyrodniczej. Z pomocą przychodzi tutaj inżynieria środowiska, która bada relacje między przemysłem i technologiami a środowiskiem. Kładzie także nacisk na zaspokojenie wielu potrzeb społeczeństwa, np. dostępu do czystej wody, powietrza i gleb, a więc odgrywa kluczową rolę w przekształcaniu rozwoju cywilizacyjnego w kierunku zrównoważonego rozwoju.

Inżynieria środowiska obejmuje swym zakresem przedsięwzięcia inżynierskie służące zachowaniu środowiska przyrodniczego w stanie równowagi, podtrzymaniu jego zdolności do samoregeneracji i samooczyszczania, a także odtwarzaniu jego walorów przyrodniczych. W przypadku dewastacji środowiska proponuje przedsięwzięcia zmierzające do przywrócenia tej równowagi. Inżynieria środowiska tworzy ponadto naukowe podstawy racjonalnego gospodarowania zasobami przyrody oraz prognozowania, oceny, zapobiegania i naprawy negatywnych skutków antropopresji. Jednym z istotnych celów inżynierii środowiska jest też edukowanie społeczeństwa odnośnie działań technicznych.

Inżynieria środowiska jest jedną z najmłodszych dyscyplin nauk technicznych, a jej podstawy teoretyczne zostały ugruntowane w ostatnich kilkudziesięciu latach. Główną przyczyną rozwoju pierwszych badań nad inżynierią środowiska był negatywny wpływ rozwoju przemysłu na środowisko naturalne w XIX wieku - znaczące pogorszenie jakości życia człowieka, wzrost zachorowań i liczby zgonów. Wprawdzie w kolejnym stuleciu w wielu obszarach gospodarki nastąpił wyraźny postęp cywilizacyjny, ale równolegle pojawiło się także wiele zagrożeń o charakterze globalnym, które wręcz wymusiły potrzebę poszukiwania technologii środowiskowych dla wzrostu gospodarczego. Do dalszego rozwoju inżynierii środowiska w XX 
oraz XXI wieku niewątpliwie przyczyniła się także realizacja założeń polityki ekologicznej, a szczególnie wdrażanie idei zrównoważonego rozwoju w skali globalnej.

\subsection{Interdyscyplinarność inżynierii środowiska}

Inżynieria środowiska obejmuje swym zakresem nauki techniczne, prawne, ekonomiczne oraz przyrodnicze, tworząc podstawy odpowiedzialnego i efektywnego gospodarowania zasobami środowiska, zgodnie z zasadami zrównoważonego rozwoju. Stosowane metody inżynierskie opierają się więc na prawach wielu innych dyscyplin naukowych, np.: fizyki, chemii, matematyki i biologii, geografii, geologii, meteorologii, zarządzania, socjologii, psychologii, prawa oraz ekonomii. Wiedza na temat otaczającego świata i rządzących nim praw przyrody zaczerpnięta z wymienionych dyscyplin stanowi elementarny poziom poznania inżynierii środowiska.

Inżynieria środowiska jako dziedzina wiedzy stosowanej zajmuje się wieloma działaniami człowieka w środowisku - w przemyśle, budownictwie, rolnictwie. Uwzględnia różne zagadnienia i kierunki badań, np. unieszkodliwianie ścieków i odpadów, melioracje wodne, zaopatrzenie w wodę, ogrzewnictwo, chłodnictwo i klimatyzację, ochronę powietrza, monitoring, ochronę środowiska i energetykę.

Inżynieria środowiska łączy wiedzę techniczną, a ściślej - inżynierską z wiedzą przyrodniczą. Jeśli chodzi o wiedzę techniczną, w kręgu zainteresowań inżynierii środowiska znajduje się głównie działanie systemów technicznych związanych z produkcją, wytwarzaniem i z technologiami ochrony środowiska. Natomiast wiedza przyrodnicza, która daje podstawy omawianej dyscyplinie, dotyczy środowiska naturalnego i jego ochrony, a przede wszystkim funkcjonowania poszczególnych elementów środowiska przyrodniczego, czynników zakłócających lub niszczących to funkcjonowanie, a także metod naprawy i ochrony i środowiska przed degradacją. Interdyscyplinarność nauk technicznych i przyrodniczych może istotnie przyczyniać się do pełniejszego poznawania i lepszego rozumienia relacji człowiek-środowisko-technika niż w przypadku innych dyscyplin naukowych. Może także stanowić ważny instrument pozwalający na praktyczne wprowadzenie zasad idei zrównoważonego rozwoju w wielu obszarach działalności człowieka, szczególnie w zielonych sektorach gospodarki, na każdym szczeblu i poziomie gospodarowania. 
Metody inżynierskie przyjazne środowisku naturalnemu są stosowane głównie w następujących dziedzinach:

- oszczędności energii;

- racjonalnego zużycia surowców naturalnych i zapobiegania ich stratom;

- minimalizacji powstawania odpadów i emisji zanieczyszczeń;

- zapewnienia bezpieczeństwa ekologicznego i procesowego;

- ochrony, kształtowania i wykorzystania poszczególnych elementów środowiska przyrodniczego (hydrosfery, atmosfery, litosfery i biosfery);

- ochrony i kształtowaniu środowiska wewnętrznego pomieszczeń i obiektów budowlanych.

Badania naukowe z zakresu inżynierii środowiska mają także charakter interdyscyplinarny. Obecnie $w$ ramach tej dyscypliny rozwiązywanych jest wiele problemów badawczych, a główne kierunki badań dotyczą procesów zachodzących w środowisku naturalnym, procesów technologicznych przetwarzania materii i energii, mechanizmów transportu i propagacji zanieczyszczeń w środowisku, środowiskowych skutków emisji i depozycji zanieczyszczeń, a także zasobów naturalnych (odnośnie ich pozyskiwania, eksploatacji i racjonalnego gospodarowania nimi).

Jednym z istotnych zadań inżynierii środowiska jest zbadanie i zbilansowanie podstawowych strumieni masy tworzących główne obiegi pierwiastków chemicznych w przyrodzie. Dotyczy to przede wszystkim tych związków chemicznych, które podtrzymują i wspomagają procesy życiowe na Ziemi, a więc: wody, związków węgla, tlenu, związków azotu, innych związków i pierwiastków biogennych (fosforu, siarki). Jednakże racjonalne pojmowanie i rozumienie procesów zachodzących w środowisku wymaga dobrej znajomości praw przyrody, a w pierwszej kolejności: prawa zachowania masy i energii, opisu szybkości procesów oraz przemian chemicznych i biochemicznych. Specjalista w zakresie inżynierii środowiska powinien znać te prawa, aby móc je następnie zastosować w technologiach i metodach inżynieryjnych służących ochronie środowiska. 


\subsection{Inżynieria ekologiczna}

Inżynieria ekologiczna to interdyscyplinarna, teoretyczna i stosowana wiedza, która ma swoje podstawy zarówno w naukach technicznych, jak i przyrodniczych. Zajmuje się zaś problematyką racjonalnego użytkowania i ochrony środowiska przyrodniczego oraz zasobów. Odgrywa kluczową rolę w rozwoju badań dotyczących zasobów przyrodniczych i ich roli w gospodarce, zagrożeń środowiska przyrodniczego, a także strat i korzyści ekologicznych powstałych w wyniku gospodarowania w środowisku. Badania naukowe bezpośrednio związane z problematyką ekologiczną odnoszą się przede wszystkim do zanieczyszczeń, przekształcenia środowiska przyrodniczego oraz opracowywania metod i rozwiązań techniczno-organizacyjnych ochrony środowiska przyrodniczego.

Inżynieria ekologiczna tworzy teoretyczne podstawy sposobów pozyskania czystej wody i energii, ochrony zasobów naturalnych, oczyszczania środowiska i odtwarzania zdewastowanych ekosystemów. Oprócz tego uczestniczy w ocenie i prognozowaniu środowiskowych skutków działalności człowieka, odnawianiu ekologicznych, sanitarnych i produkcyjnych wartości środowiska, analizie produktów i technologii środowiskowych pod kątem ich wpływu na środowisko, minimalizowaniu wytwarzania odpadów, a także przyczynia się do większej produktywności zasobów naturalnych.

Obecnie wiele działań podejmowanych w ramach inżynierii ekologicznej dotyczy głównie technologii i metod zagospodarowywania ścieków i odpadów, produkcji energii ze źródeł odnawialnych, metod doczyszczania wód oraz ochrony wód przed zanieczyszczeniami obszarowymi. Są one zgodne z aktualnymi kierunkami polityki ekologicznej naszego państwa.

Rezultaty badań w zakresie inżynierii ekologicznej (w postaci konkretnych rozwiązań, technologii i metod inżynieryjnych) mogą być bardzo przydatne przy podejmowaniu wszelkich działań w środowisku na każdym poziomie - tak lokalnym, jak i globalnym. Mogą między innymi służyć przedsiębiorcom w opracowywaniu strategii postępowania wobec środowiska lub strategii „czystszej produkcji” zgodnie z koncepcją zrównoważonego rozwoju. 


\section{Literatura}

Wiatr I. i in., Ekoinżynieria. Podstawy działań naprawczych w środowisku, Wydawnictwo Naukowe G.B., Lublin 2003.

Zarzycki R., Imbierowicz M., Stelmachowski M., Wprowadzenie do inżynierii $i$ ochrony środowiska, t. 1: Ochrona środowiska naturalnego, Wydawnictwa Naukowo-Techniczne, Warszawa 2007. 


\section{Rozdział 2}

\section{Wybrane procesy w inżynierii środowiska}

\subsection{Wprowadzenie}

Substancje występujące w przyrodzie mogą być jednorodne lub niejednorodne fizycznie. Mogą występować w postaci roztworów właściwych, mieszanin koloidalnych czy zawiesin. Najczęściej jednak spotykamy się z układami dyspersyjnymi.

Stan rozproszenia koloidalnego jest rozpowszechniony zarówno w świecie przyrody ożywionej (białka, węglowodany, pektyny), nieożywionej (gliny, mgły), jak i wśród związków otrzymywanych sztucznie. Zanieczyszczenia wody i powietrza to również często koloidalne układy różnych związków chemicznych.

Koloidy to układy dyspersyjne, najczęściej dwuskładnikowe, które charakteryzują się rozmiarem cząstek fazy rozproszonej między 1 a $200 \mathrm{~nm}$. Mają wygląd układów fizycznie jednorodnych, jednak w rzeczywistości składniki nie są ze sobą zmieszane cząsteczkowo. Wyróżniamy koloidy liofobowe i liofilowe. Cząstki koloidu liofobowego przemieszczają się stałym nieuporządkowanym ruchem i zderzając się ze sobą, mogą łączyć się w większe cząstki. Po osiągnięciu odpowiedniej wielkości cząstki tracą zdolność utrzymywania się w roztworze i opadają. Koagulacja zoli liofilowych jest odwracalna. Po dodaniu rozpuszczalnika do żelu przechodzi on ponownie w zol (peptyzacja).

Przykładowo ścieki są wieloskładnikową mieszaniną wody oraz związków organicznych i nieorganicznych. Mogą one występować w postaci roztworów rzeczywistych jonowych lub układów koloidalnych. Forma, w jakiej dana substancja lub rodzaj materii pozostaje w wodzie, zależy od stopnia dyspersji (rozproszenia), którego miarą jest stosunek objętości danej cząstki do jej powierzchni.

Techniki separacji to najczęściej stosowane procesy technologiczne do zmniejszenia ilości zanieczyszczeń w środowisku. Służą przede wszystkim do zatężania, czyli usuwania rozpuszczalnika (np. wody) z roztworu 
rozcieńczonego, do oczyszczania, czyli usuwania zanieczyszczeń z wody, jak również do frakcjonowania, a więc rozdzielania substancji w mieszaninie lub roztworze na dwa lub więcej składników.

\subsection{Klasyfikacja procesów}

W ogólnym ujęciu ochrona elementów środowiska naturalnego, na przykład wód w inżynierii środowiska, polega na rozdzieleniu składników tych mieszanin i usuwaniu z nich zanieczyszczeń. Można tego dokonać za pomocą wielu procesów mechanicznych, fizycznych i chemicznych, jak choćby w odnowie i uzdatnianiu wody, procesach oczyszczania gazów odlotowych czy unieszkodliwiania odpadów stałych. Zasadniczą funkcją procesów w inżynierii środowiska jest jednak usunięcie substancji zanieczyszczających wodę i powietrze, a niekiedy również gleby.

Procesy jednostkowe (zwane również operacjami jednostkowymi) mają głównie za zadanie: transport ciał na odległość, zmianę temperatury i stanu skupienia substancji, zmianę kształtu ciała stałego, rozdzielenie mieszanin i roztworów ciał stałych, ciekłych i gazowych, a także mieszanie ciał stałych i gazowych. Podstawowe znaczenie przy wyborze metody rozdziału mieszanin mają następujące właściwości fizyczne:

- stan skupienia składników mieszaniny (określony przez temperaturę topnienia i wrzenia);

- gęstość albo różnica gęstości pomiędzy składnikami mieszaniny;

- rozpuszczalność w różnych rozpuszczalnikach lub roztworach;

- właściwości elektrostatyczne, magnetyczne i wiele innych.

W literaturze przedmiotu proponuje się wiele sposobów klasyfikacji procesów jednostkowych, ale najczęściej wyróżnia się:

- dynamiczne, do których można zaliczyć: transport, rozdrabnianie, flotację, odpylanie, sedymentację, filtrację, wirowanie, mieszanie;

- cieplne, a wśród nich: chłodzenie i grzanie, skraplanie i wrzenie, zatężanie roztworów;

- dyfuzyjne, których przykłady to: destylacja, ekstrakcja, absorpcja, desorpcja, adsorpcja; 
- dyfuzyjno-cieplne, czyli: krystalizacja, suszenie, nawilżanie, permeacja, topnienie strefowe, termodyfuzja;

- termodynamiczne, do których zaliczamy: chłodzenie, wymrażanie gazów, kompresję.

Poniżej przedstawiono krótką charakterystykę wybranych procesów fizykochemicznych stosowanych w inżynierii środowiska.

\subsection{Ogólna charakterystyka wybranych procesów}

Strącanie chemiczne jest procesem chemicznym polegającym na usunięciu z wody związków w postaci osadów trudno rozpuszczalnych i praktycznie nierozpuszczalnych. Kationy metali łączą się w tym procesie $z$ anionami reszt kwasowych i wytrącają się osady, które następnie usuwa się $z$ wody w procesach sedymentacji i filtracji.

Koagulacja to proces przejścia zolu w żel w wyniku agregacji cząstek koloidalnych. To inaczej zlepianie się cząstek (np. tworzących aerozol lub roztwór koloidalny) w większe zespoły, tzw. agregaty. Przykładowo w technologii wody i ścieków koagulacja służy do usuwania koloidów, barwy, zawiesin trudno opadających i wielu mikrozanieczyszczeń.

W procesie koagulacji wyróżnia się dwie fazy: destabilizacji i flokulacji. Faza destabilizacji, trwająca kilka sekund, występuje bezpośrednio po dodaniu koagulantu. Składa się z licznych reakcji chemicznych i fizycznego współdziałania między wodą i powierzchnią zawieszonych cząstek. Mechanizm destabilizacji polega na obniżeniu potencjału elektrokinetycznego, dehydratacji i utlenieniu koloidów ochronnych. Natomiast faza flokulacji obejmuje procesy fizyczne i zachodzi pod wpływem oddziaływań i sił wewnętrznych i zewnętrznych, powodujących skuteczne zderzanie zdestabilizowanych cząstek koloidu, co prowadzi do utworzenia kłaczków.

Sedymentacja jest jednym z podstawowych procesów wykorzystywanych w oczyszczaniu wody i ścieków oraz powietrza, w którym cięższe składniki roztworu opadają na dno naczynia pod własnym ciężarem. Polega na rozdzieleniu mieszaniny na czystą ciecz i ziarna fazy stałej na skutek opadania ziaren na nieporowatą powierzchnię zbiornika pod wpływem siły grawitacyjnej lub innego wymuszonego ruchu ziaren (np. siły odśrodkowej). 
Podstawowym celem sedymentacji jest uzyskanie czystej cieczy i zagęszczonej fazy stałej poprzez usunięcie z fazy ciągłej (cieczy bądź gazu) cząsteczek o gęstości większej od jej gęstości, czyli cząsteczek opadających. W inżynierii środowiska szczególne znaczenie ma sedymentacja zawiesin w cieczach, a głównie w roztworach wodnych. Procesy sedymentacyjne mają na celu:

- zagęszczanie, które prowadzi do uzyskania zawiesiny o większej gęstości przez częściowe usuwanie z niej cieczy;

- klarowanie, polegające na usunięciu z cieczy niewielkiej ilości ciał stałych w celu uzyskania jej przezroczystości;

- rozwarstwianie, czyli rozdzielenie ciekłego, niejednorodnego układu na dwie lub więcej warstw różniących się jakością fazy rozproszonej.

W zależności od rodzaju i zawartości zawiesin wyróżnia się sedymentację cząstek ziarnistych oraz cząstek kłaczkowatych. Zawiesiny ziarniste są to takie zawiesiny, w których można zaobserwować poszczególne ziarna. Zawiesiny kłaczkowate są charakterystyczne dla układów koloidalnych, w których sedymentują całe agregaty o różnej strukturze przestrzennej, a osad jest silnie rozpulchniony i zawiera znaczne ilości cieczy.

Filtracja jest procesem stosowanym podczas oczyszczania wody, ścieków, powietrza oraz gleby (np. do oczyszczania powietrza w urządzeniach technicznych zwanych filtrami bądź prasami filtracyjnymi) albo też usuwania zawiesin po procesach chemicznego strącania lub koagulacji. Zapewnia usuwanie z oczyszczonej mieszaniny cząstek o średnicy większej niż 0,1 um lub usuwanie wody z materiału stałego. Jest to proces złożony, składa się z kilku procesów jednostkowych, które wpływają na usuwanie podczas filtracji cząstek, które są mniejsze niż pory złóż filtracyjnych. W początkowej fazie procesu filtracji cząstki fazy stałej osiadają na przegrodzie filtracyjnej, następnie na osadzonej fazie stałej, tworząc porowatą strukturę osadu filtracyjnego. O przebiegu procesu filtracji decydują właściwości hydrauliczne warstwy filtracyjnej, a więc: porowatość uziarnienia, szorstkości cząstek, sferyczność określona kształtem cząstek i sposobem ich ułożenia. Podczas filtracji ciecz przepływa w danym kierunku i z określoną prędkością przez materiał porowaty, który jest złożem filtracyjnym. Podczas zatrzymywania cząstek na złożu filtracyjnym współdziałają mechanizmy transportu i przyciągania. Mechanizm zatrzymywania zanieczyszczeń obejmuje wiele zjawisk, między 
innymi: cedzenie, sedymentację, flokulację, kohezję (spójność), adhezję (przyleganie cieczy do ciała stałego), dyfuzję, adsorpcję i oddziaływania elektrostatyczne.

Ekstrakcja to proces selektywnego rozdzielania mieszanin za pomocą rozpuszczalnika ciekłego lub gazu, stosowany najczęściej wówczas, gdy zachodzi potrzeba wydzielenia z mieszaniny i otrzymania pojedynczego składnika w czystej postaci. Polega na wykorzystaniu niejednakowej rozpuszczalności składników mieszaniny w rozpuszczalniku. Do mieszaniny, którą należy rozdzielić, dodaje się właśnie taki rozpuszczalnik, aby tylko jeden ze składników dobrze się w nim rozpuszczał. Roztwór zawierający ekstrahujące się substancje wytrząsa się w specjalnych naczyniach (rozdzielaczach), a po dokładnym wymieszaniu całości oddziela się składnik gorzej rozpuszczalny. Podczas ekstrakcji stężenie ekstrahowanej substancji w rozpuszczalniku pierwotnym maleje, a w ekstrahencie rośnie. Czynność powtarza się wielokrotnie w celu uzyskania jak najlepszego rozdziału składników mieszaniny. Po osiągnięciu stanu równowagi stężenia substancji rozpuszczonej w obu fazach nie zmieniają się.

Rozróżnia się układy ekstrakcyjne typu: ciecz-ciecz, ciało stałe-ciecz, ciało stałe-gaz. Ekstrakcja w układzie ciecz-ciecz najlepiej zachodzi w środowisku wodnym, ponieważ woda jest bardzo dobrym rozpuszczalnikiem większości substancji nieorganicznych, w przeciwieństwie do substancji organicznych. Natomiast rozpuszczalniki organiczne bardzo dobrze rozpuszczają związki węgla niebędące elektrolitami. Dzięki zastosowaniu procesu ekstrakcji rozdzielono na skalę techniczną wiele mieszanin następujących związków: tłuszczów, olejów, wosków, preparatów biochemicznych, antybiotyków, witamin, hormonów, barwników oraz wielu innych.

Sorpcja jest zwykle jednym z ostatnich elementów instalacji i powinna być poprzedzona procesami, które usuną zawiesiny i pyły oraz substancje koloidalne z oczyszczanych mediów (np. koagulacją, filtracją, sedymentacją). Procesy sorpcji stanowią istotny element wielu układów technologicznych wykorzystywanych w inżynierii środowiska i znalazły liczne zastosowania praktyczne, a najważniejsze z nich to:

- użycie węgla aktywnego w technologii wody;

- w procesach flotacji;

- w rozdzielaniu składników metodą pianową; 
- w analizie chromatograficznej, z wykorzystaniem zdolności niektórych adsorbentów do selektywnego adsorbowania pewnych substancji;

- w procesach membranowych;

- w procesach wymiany jonowej.

Wśród procesów sorpcji istotne miejsce zajmuje adsorpcja, która polega na wykorzystaniu zdolności podłoża do przyczepiania na powierzchni składników mieszaniny. Inaczej mówiąc, jest to zjawisko gromadzenia się pewnych substancji na granicy faz, w warstwach powierzchniowych oddzielających od siebie poszczególne fazy. Granicą faz może być powierzchnia odgraniczająca: ciało stałe-ciecz, ciało stałe-gaz, ciało stałe-ciało stałe, ciecz-ciecz lub ciecz-gaz. Substancję, na powierzchni której zachodzi adsorpcja, nazywamy adsorbentem, a substancja zaadsorbowana to adsorbat. W procesie tym istotnym czynnikiem jest dobrze rozwinięta powierzchnia podłoża adsorbenta, tak jak w przypadku specjalnie spreparowanego węgla aktywnego, nierozpuszczalnych tlenków metali czy krzemionki. Powierzchnia czynna adsorbenta, na którą składają się również zawarte w nim różne pory i kanaliki, zwiększa się wraz ze wzrostem stopnia jego rozdrobnienia.

Można wyróżnić różne siły oddziaływania między adsorbentem i adsorbatem, a mianowicie: przyciąganie elektryczne, działanie wynikające z działania sił spójności, ale może też zachodzić reakcja chemiczna. W związku z tym wyróżnia się trzy rodzaje adsorpcji: jonowymienną, fizyczną i chemiczną. Pierwsze dwie są procesami odwracalnymi, trzecia zaś jest często procesem nieodwracalnym bądź częściowo odwracalnym.

Jednym z najstarszych i najczęściej stosowanych adsorbentów jest węgiel aktywny (zwany też aktywowanym). Jest on wytwarzany przez ogrzewanie stałych substancji organicznych do temperatury $1200 \mathrm{~K}$ w atmosferze redukującej, w wyniku czego otrzymuje się porowate cząstki, zbudowane z dużej ilości obojętnych atomów węgla, pomiędzy którymi brak jest potencjału elektrycznego i stąd jego powinowactwo do związków niepolarnych.

Warto również wspomnieć o zjawisku absorpcji. Proces ten polega na dyfuzyjnym przenoszeniu cząstek gazu do cieczy. Przykładowo gazowy chlor jest adsorbowany przez węgiel aktywny, ale absorbowany przez wodę. Kolejne zasadnicze etapy tego procesu polegają na: przenoszeniu składnika do powierzchni cieczy, jego rozpuszczeniu w warstwie 
granicznej na powierzchni cieczy i w końcowym etapie - przenoszeniu składnika zaabsorbowanego w głąb cieczy. Wobec tego głównym celem absorpcji jest usuwanie zanieczyszczeń gazowych wskutek ich fizycznego rozpuszczenia w cieczy lub przy współudziale reakcji chemicznej. W tym celu konieczne są między innymi: odpowiednio długi czas kontaktu oraz siła przepływu gazu przez ciecz. Jeżeli stężenie zanieczyszczeń jest stosunkowo duże, absorpcja może stanowić efektywną metodę odzysku wartościowych substancji z rozdzielanych na poszczególne składniki mieszanin.

Procesy utleniania i redukcji są to takie przemiany chemiczne, podczas których następuje wymiana elektronów pomiędzy substancją utleniającą (utleniaczem) a redukującą (reduktorem). Procesowi redoks zawsze towarzyszy zmiana stopnia utlenienia pierwiastków. W technologiach wody i ścieków często są stosowane procesy utleniania zanieczyszczeń organicznych silnymi utleniaczami, takimi jak: chlor, tlenek chloru (IV), ozon, manganian (VII) potasu i nadtlenek wodoru. Procesy utlenienia są w tym przypadku zazwyczaj powiązane z dezynfekcją wody lub ścieków. Utlenieniu ulegają obecne w wodzie zanieczyszczenia, sam utleniacz ulega natomiast redukcji. Stosowane utleniacze powinny utleniać obecne w wodzie związki organiczne do dwutlenku węgla i wody, jednak w praktyce jest inaczej, gdyż obok reakcji wprowadzania i oddawania tlenu zachodzą równolegle inne, jak się to dzieje na przykład w procesie chlorowania. Poza tym substancje organiczne, ze względu na swoją złożoną budowę, są niekiedy odporne na utlenianie, dlatego skuteczność utleniania tych zanieczyszczeń zwykle jest mniejsza niż substancji nieorganicznych.

Procesy elektrochemiczne polegają na wykorzystaniu odpowiednich reakcji chemicznych w celu wytworzenia energii elektrycznej ( $\mathrm{np}$. w ogniwach galwanicznych lub paliwowych oraz akumulatorach) bądź na doprowadzeniu do środowiska energii elektrycznej w celu wywołania odpowiednich przemian chemicznych (w elektrolizerze). W zależności od celu i sposobu ich prowadzenia procesy elektrochemiczne pobierające energię mogą zachodzić w wodnych roztworach elektrolitów, w środowisku stopionych soli lub w środowisku gazowym. Znane są także procesy elektrotermiczne, w których energia elektryczna dostarcza ciepło o znacznie korzystniejszych parametrach niż konwencjonalne źródła.

Interesującym procesem elektrochemicznym stosowanym w inżynierii środowiska jest elektroflotacja, którą stosuje się często zamiast sedymentacji. Jest to jednak możliwe wtedy, gdy usuwane cząstki stałe mają 
gęstość mniejszą od wody lub różnica gęstości zawiesin i wody jest niewielka. Czynnikiem powodującym rozdzielenie faz i wyniesienie fazy stałej na powierzchnię mogą być pęcherzyki gazu i wówczas mamy do czynienia z flotacją gazową. W procesie tym źródłem pęcherzyków gazu jest elektroliza wody.

Celem flotacji stosowanej na przykład w oczyszczaniu wody jest rozdział fazy stałej (cząstek zawieszonych) od fazy ciekłej (wody). Jednak ze względu na wysokie koszty elektroflotacja wykorzystywana jest tylko przy oczyszczaniu niewielkich ilości ścieków i wody. Ilość zużywanej energii elektrycznej jest czasem niewspółmiernie duża w stosunku do uzyskiwanych efektów oczyszczania. Jednakże można posługiwać się tą metodą (zastępując nią sedymentację) w układach oczyszczania barwnych wód powierzchniowych charakteryzujących się dużą zawartością glonów oraz małą mętnością i zasadowością.

Procesy wymiany jonowej stosuje się w celu całkowitego lub częściowego usunięcia z wody substancji rozpuszczonych w postaci kationów i anionów. Jest to reakcja chemiczna, która zachodzi w wyniku kontaktu (w warunkach statycznych bądź dynamicznych) fazy stałej wymieniacza jonowego z roztworem zawierającym cząstki jonowe. Odwracalność reakcji jonowymiennej stwarza możliwość prowadzenia procesu wymiany jonowej i procesu odwrotnego, czyli regeneracji wymieniacza jonowego. Szybkość reakcji jonowymiennych zależy od kilku czynników, a mianowicie: rodzaju wymienianych jonów, cech wymieniaczy jonowych, stężenia elektrolitu, warunków prowadzenia procesu, składu fizyczno-chemicznego oczyszczanych roztworów lub też stopnia uwodnienia jonów biorących udział w wymianie. Ze względu na rodzaj wymienianych jonów jonity dzielą się na kationity i anionity. Kationity mają charakter kwasów lub ich soli, natomiast anionity zasad lub ich soli.

Wymiana jonowa wykorzystywana jest najczęściej w technologii wody i ścieków do oczyszczania wód do celów przemysłowych i pozyskania wody o określonym stopniu zasolenia. Główne kierunki zastosowania tego procesu są obecnie następujące:

- zmiękczanie wody - w zależności od wymaganego stopnia zmniejszenia twardości wody oraz rodzaju usuwanej twardości (węglanowej, niewęglanowej);

- demineralizacja i odsalanie wody;

- usuwanie fosforanów i azotanów; 
- usuwanie azotu amonowego, metali i radionuklidów;

- usuwanie zanieczyszczeń organicznych.

Techniki membranowe są wykorzystywane w inżynierii środowiska do rozdzielania składników mieszanin ciekłych i niekiedy gazowych na poziomie jonowym, cząsteczkowym lub koloidalnym. Charakterystykę tych technik zawarto w kolejnym, trzecim rozdziale niniejszego podręcznika.

\section{Literatura}

Biernacka E., Suchecka T., Techniki membranowe w ochronie środowiska, Wydawnictwo SGGW, Warszawa 2004.

Gromiec M., Słowik N. (red.), Zastosowanie nowych technologii w sektorze ochrony środowiska, Wydawnictwo NFOŚiGW, Warszawa 2006.

Janosz-Ratajczyk M. (red.), Wybrane procesy jednostkowe w inżynierii środowiska, Wydawnictwo Politechniki Częstochowskiej, Częstochowa 2004.

Kowal A.L., Świderska-Bróż M., Oczyszczanie wody. Podstawy teoretyczne i technologiczne, procesy i urządzenia, Wydawnictwo Naukowe PWN, Warszawa 2009.

Zarzycki R., Imbierowicz M., Stelmachowski M., Wprowadzenie do inżynierii i ochrony środowiska, t. 1: Ochrona środowiska naturalnego, Wydawnictwa Naukowo-Techniczne, Warszawa 2007. 


\section{Rozdział 3}

\section{Techniki membranowe}

\subsection{Wprowadzenie}

Ze względu na wysoki i stale wzrastający poziom zanieczyszczenia środowiska istnieje konieczność poszukiwania ekonomicznie uzasadnionych, wysoko skutecznych nowych technik i metod inżynieryjnych do rozdzielania mieszanin w celu ich oczyszczenia, w tym szczególnie oczyszczania lub utylizacji ścieków i innych strumieni odpadowych. W związku z tym od wielu lat między innymi w ramach dyscypliny naukowej, jaką jest inżynieria środowiska, rozwijają się coraz bardziej zaawansowane i złożone metody usuwania zanieczyszczeń, pozwalające na redukcję odprowadzanych zanieczyszczeń na odpowiednio wysokim poziomie.

Wiele zanieczyszczeń występujących w środowisku charakteryzuje się bardzo niskim stężeniem, ale mimo to często stanowią one duże zagrożenie dla zdrowia ludzi. Nowoczesne metody analityczne przyczyniają się do wykrywania tych zanieczyszczeń i ze względów zdrowotnych i technologicznych należy je ze środowiska usunąć. Istotne jest jednak to, że im niższe stężenie substancji toksycznych w roztworach rozcieńczonych, tym wyższy koszt usuwania tych substancji. W takich sytuacjach korzystnym rozwiązaniem jest wdrażanie technologii membranowych, które pozwalają na usunięcie bardzo różnych zanieczyszczeń oraz na ich separację już na poziomie molekularnym lub jonowym. Są one używane od ponad stu lat. Szersze zastosowanie znalazły pod koniec lat 40. ubiegłego wieku między innymi w mikrobiologii (do usuwania bakterii z roztworów) i w badaniach medycznych, a obecnie w różnych układach technologicznych uzdatniania wody i oczyszczania ścieków. Techniki membranowe znajdują coraz więcej zastosowań i są najbardziej dynamicznie rozwijającą się dziedziną techniki w obszarze separacji składników mieszanin. Należy podkreślić, że większość działających dzisiaj tradycyjnych systemów uzdatniania wód powierzchniowych i podziemnych oraz oczyszczania ścieków charakteryzuje się bardzo złożonymi 
układami technologicznymi. Alternatywą dla nich są właśnie techniki membranowe, a przede wszystkim te, w których wykorzystano różnicę ciśnień po obu stronach membrany.

\subsection{Istota technik membranowych}

Procesy membranowe należą do grupy metod separacji. Pozwalają na wydzielenie lub zatężanie danego zanieczyszczenia na poziomie molekularnym lub jonowym, nie eliminując go z systemu. Mogą być stosowane jako operacje samodzielne bądź w połączeniu $z$ innymi technikami separacji lub reaktorami, tworząc tzw. procesy hybrydowe. Dobrym przykładem może być połączenie ultrafiltracji i adsorpcji na sproszkowanym węglu aktywnym w celu skutecznego usuwania mikrozanieczyszczeń, w tym również substancji lotnych w procesach uzdatniania wody do picia. Często łączy się również ultrafiltrację z utlenieniem w celu usunięcia żelaza i manganu, a także ultrafiltrację $z$ bioreaktorem $w$ celu usunięcia azotanów. Na rysunku 3.1 przedstawiono ogólny podział technik membranowych jako jednej z technik separacji, w zależności od wielkości cząstek substancji separowanych tymi technikami.

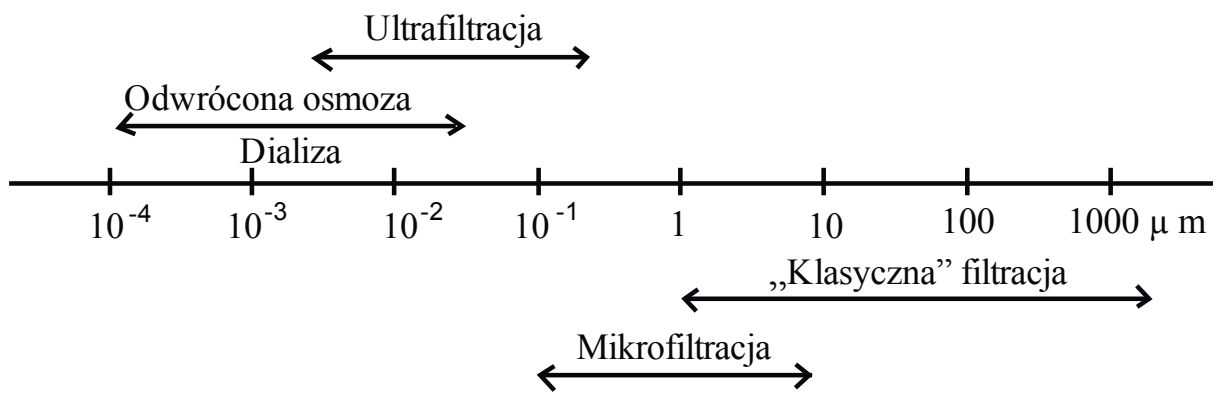

Rys. 3.1. Ogólny podział technik membranowych, w zależności od wielkości cząstek substancji separowanych

Źródło: opracowanie własne na podstawie R. Zarzycki i in., Wprowadzenie do inżynierii i ochrony środowiska, t. 1: Ochrona środowiska naturalnego, Wydawnictwa NaukowoTechniczne, Warszawa 2007, s. 292.

Techniki membranowe to specyficzna grupa procesów fizykochemicznych i coraz częściej zastępują one konwencjonalne techniki uzdatniania czy też oczyszczania wody. Przy odpowiednim dobraniu wielkości 
porów membrana może być filtrem absolutnym i efektywnie separować zanieczyszczenia bez konieczności dodawania reagentów. Jednocześnie strumień odpadowy pozbawiony jest produktów ubocznych reakcji chemicznych czy innych substancji wprowadzanych w trakcie uzdatniania konwencjonalnego i zawiera jedynie naturalne zanieczyszczenia usunięte $z$ wody. Procesy membranowe umożliwiają ponadto uzyskanie wody o stałej jakości, niezależnie od jakości wody użytej do procesu.

\subsection{Membrany}

Membrany to cienkie przegrody pomiędzy dwiema fazami (ciekłymi bądź gazowymi) pozwalające na selektywny transport masy lub preferencyjne przenoszenie składników bądź mieszanin. Procesy te zachodzą w taki sposób, że substancje są wymieniane między fazami z szybkością zależną od rodzaju membrany i właściwości faz.

Surowcem do produkcji membrany mogą być organiczne, nieorganiczne, syntetyczne lub naturalne materiały, na przykład trioctan celulozy, poliamidy, poliamidy aromatyczne, polieteroamidy, polisulfony, polichlorek winylu, kopolimery poliakrylonitrylu, polichlorku winylu, nitroceluloza, polipropylen oraz wiele innych. Membrany nieorganiczne są wytwarzane z metalu, szkła, węgla czy ceramiki. Biologiczną membranę stanowią plazma oraz błona komórkowa.

Obecnie coraz częściej stosuje się syntetyczne membrany polimerowe, które zastępują wrażliwe na degradację biologiczną oraz ulegające w wodzie hydrolizie membrany z octanu celulozy. Wybór surowca i sposób wykonania membrany zależą głównie od przeznaczenia, a także od warunków, w których ma być wykorzystana, czyli od odczynu, temperatury oraz obecności substancji degradujących powierzchnię membrany.

Membrana jest rodzajem filtru i podobnie jak w procesie filtracji co najmniej jeden ze składników mieszaniny może bez przeszkód przez nią przechodzić, natomiast pozostałe są przez nią zatrzymywane (w różnym stopniu). Jednak najistotniejsza różnica w stosunku do tradycyjnego filtra polega na tym, że za pomocą membran można rozdzielać substancje aż do poziomu molekularnego.

Membrany powinny charakteryzować się przede wszystkim dużą wydajnością hydrauliczną, dobrymi właściwościami separacyjnymi oraz odpornością na działanie czynników mechanicznych, termicznych i chemicznych. Przy spełnieniu tych wymagań, jak również przy właściwym przygotowaniu użytej do procesu wody przed procesem membranowym, 
możliwe są stabilność przepływu oraz długa praca membran. O efektywności procesów membranowych decydują również wewnętrzna budowa membran i ich porowatość.

W literaturze przedmiotu dotyczącej technik membranowych można doszukać się różnych klasyfikacji membran. Ze względu na transport masy, jaki w nich zachodzi, można podzielić membrany na porowate, w których transport zwany permeacją zachodzi przez pory, a także rozpuszczalnościowo-dyfuzyjne, w których transport zachodzi na skutek dyfuzji.

Permeat to ta część strumienia, jaka przeniknęła przez membranę, ponieważ zawiera cząstki, których wymiary umożliwiają dyfuzję przez cienkowarstwową membranę. Natomiast retentant stanowi część roztworu, jaka pozostaje w roztworze po stronie nadawy, ponieważ zawiera cząstki, których rozmiary przekraczają rozmiary porów membrany i nie mogą przez nią przeniknąć.

\subsection{Charakterystyka wybranych technik membranowych}

Do procesów membranowych najczęściej stosowanych w oczyszczaniu wody i ścieków oraz odnowie wody należą: mikrofiltracja, nanofiltracja, ultrafiltracja, odwrócona osmoza, dializa, elektrodializa, perwaporacja, destylacja membranowa oraz permeacja gazowa. Procesy te pozwalają na usunięcie z oczyszczanych roztworów składników (cząstek, cząsteczek i jonów) o wymiarach w zakresie od $10^{1}$ do ok. $10^{-3}$ $\mu \mathrm{m}$. W ultrafiltracji i odwróconej osmozie siłą napędową jest różnica ciśnień, natomiast w elektrodializie - różnica potencjału elektrycznego. Procesy te różnią się również mechanizmem rozdziału. W ciśnieniowych procesach membranowych pod wpływem przyłożonego ciśnienia rozpuszczalnik oraz substancje rozpuszczone przechodzą przez membranę, natomiast większe cząsteczki są zatrzymywane.

Osmoza polega na selektywnym przenoszeniu substancji o małych rozmiarach cząstek przez membrany, na przykład przez warstwę celofanu. Substancje, których średnica jest mniejsza niż średnica porów w membranie, przechodzą przez nią swobodnie i są wymywane przez przepływającą na zewnątrz membrany czystą wodę. Oczyszczanie tą metodą stosuje się powszechnie w sztucznych nerkach.

Odwrócona osmoza służy do oddzielania wody (jako rozpuszczalnika) od substancji rozpuszczonej (o małej masie cząsteczkowej). Podstawą procesu jest zjawisko osmozy na transporcie rozpuszczalnika przez 
membranę półprzepuszczalną, tzn. przepuszczalną dla rozpuszczalnika, a nieprzepuszczalną dla substancji rozpuszczonych. Istotą działania jest tutaj różnica aktywności rozpuszczalnika w roztworach rozdzielonych przez membranę. Jeżeli membrana oddziela roztwory o różnym ciśnieniu osmotycznym, to następuje osmotyczny przepływ rozpuszczalnika do roztworu o większym stężeniu. Rozcieńczanie roztworu bardziej stężonego odbywa się natomiast do momentu uzyskania równowagi osmotycznej, tzn. gdy różnica ciśnień po obu stronach membrany będzie równa ciśnieniu osmotycznemu.

Ultrafiltracja zatrzymuje substancje niejonowe i wykorzystywana jest do usuwania z roztworów cząstek koloidalnych i wysokocząsteczkowych substancji rozpuszczonych. Separacja substancji rozpuszczonych polega na fizycznym odsiewaniu. Sprawność procesu zależy od porowatości membrany i wielkości cząstek substancji rozpuszczonej. Membrany ultrafiltracyjne charakteryzują się stosunkowo dużą wydajnością hydrauliczną, dobrymi właściwościami separacyjnymi, a także odpornością na działanie czynników zewnętrznych. Polisulfon jest jednym z najczęściej używanych do wytwarzania membran ultrafiltracyjnych polimerów.

Nanofiltracja jest obecnie drugą na świecie technologią membranową pod względem wydajności i liczby instalacji. Na świecie pracuje kilkaset instalacji nanofiltracyjnych do uzdatniania wody, przy czym większość z nich w USA. Jest stosowana jako alternatywny proces zmiękczania wody w stosunku do kosztownego zmiękczania chemicznego.

Perwaporacja to membranowy proces rozdziału składników mieszaniny ciekłych związków chemicznych na drodze destylacji, głównie próżniowej, któremu towarzyszą zmiana stanu skupienia permeatu i jego dyfuzja przez membranę. Wykorzystuje się przeważnie polimerowe membrany nieporowate określane potocznie jako gęste lub membrany ceramiczne. Separacja wynika z różnic w rozpuszczalności poszczególnych składników w membranie oraz różnic w szybkości ich dyfuzji przez tę membranę. Jest to proces alternatywny dla odwróconej osmozy. W celu jego usprawnienia często stosuje się obniżone ciśnienie po stronie permeatu.

Perwaporację wykorzystuje się głównie do odwadniania etanolu, do usuwania lub odzyskiwania lotnych związków organicznych z wody oraz do rozdziału mieszanin związków organicznych różniących się polarnością. W stosunku do metod tradycyjnych proces charakteryzuje się wieloma zaletami. Jest wysoce selektywny, efektywny dla roztworów 
rozcieńczonych, przyjazny środowisku, a przy produkcji bezwodnego etanolu pozwala obniżyć koszty o $25-50 \%$ w porównaniu z destylacją, głównie dzięki mniejszym wymaganiom energetycznym.

Proces elektrodializy przebiega dzięki różnicy potencjału elektrycznego po obu stronach membrany, przez którą transportowane są jony z roztworu o stężeniu mniejszym do roztworu o stężeniu większym. Wytworzenie potencjału elektrycznego powoduje selektywną elektromigrację jonów (kationów i anionów) przez membrany. Końcowym efektem jest zwiększenie stężenia jonów w komorach elektrodializera. Roztwór rozcieńczony nazywa się dializatem, a roztwór zatężony - solanką (jeśli zachodzi proces odsalania wód słonawych i słonych). Na katodzie wydziela się wodór, na anodzie zaś tlen. W wypadku wód zawierających duże stężenia chlorków na anodzie może wydzielać się chlor. Gazy wydzielone na elektrodach usuwane są z komór elektrodowych.

Interesującym rozwiązaniem w zakresie technik membranowych są bioreaktory membranowe. Można w nich prowadzić równocześnie kilka jednostkowych procesów oczyszczania, na przykład procesy biologiczne z fizyczną separacją za pomocą membran. Należy wówczas zanurzyć moduł membranowy w bioreaktorze. Głównym problemem eksploatacyjnym instalacji membranowych jest zjawisko blokowania membran, które może prowadzić do spadku wydajności procesu, skrócenia cyklu pracy membran i wzrostu kosztów eksploatacyjnych. W celu ograniczenia wpływu tego zjawiska na pracę instalacji zaleca się stosowanie układów zintegrowanych, czyli sekwencyjnie połączonych procesów membranowych, przede wszystkim ciśnieniowych z fizyczno-chemicznymi lub biologicznymi metodami wstępnego oczyszczania i końcowego doczyszczania.

\subsection{Zastosowanie technik membranowych w gospodarce}

Procesy membranowe wykorzystywane są głównie do odsalania wód słonawych i wody morskiej, do przygotowania wody ultraczystej oraz do zmiękczania wody i usuwania z niej radionuklidów.

Przemysłowe zastosowanie metod membranowych jest dość powszechne w sektorach metalurgicznym, spożywczym i mleczarskim, w przetwórstwie chemicznym, w przemyśle celulozowo-papierniczym oraz w farbiarniach. Membrany służą również odsalaniu i zamykaniu obiegów wodnych w galwanizerniach. W tym przypadku szczególnie korzystne efekty uzyskuje się przy usuwaniu takich substancji, jak: 
glikole polietylenowe, środki powierzchniowo czynne, barwniki, oleje mineralne i inne związki organiczne o stosunkowo dużych masach cząsteczkowych.

Proces odsalania wód metodą odwróconej osmozy przeprowadza się w celu uzyskania wody do picia wysokiej jakości oraz na potrzeby gospodarcze, jak również do odsalania wód z wyrobisk górniczych po eksploatacji węgla kamiennego. Należy podkreślić, że proces ten charakteryzuje się stosunkowo niewielkim zużyciem energii i dzięki także wielu innym zaletom stał się przyjaznym ekologicznie źródłem wody słodkiej w wielu regionach świata.

Nowoczesne membrany bardzo dobrze nadają się również do oczyszczania ścieków, także tych o podwyższonej temperaturze. Zastosowanie technik membranowych w technologii oczyszczania ścieków z przemysłu spożywczego jest dość powszechne, nie tylko ze względu na ochronę środowiska, ale także ze względu na możliwości odzyskiwania wartościowych substancji. Na przykład w przetwórstwie mleka istnieje potrzeba odpowiedniego, zgodnego z wymaganiami ochrony środowiska zagospodarowania lub unieszkodliwienia odpadowej serwatki, która stanowi blisko $90 \%$ objętości mleka wykorzystywanego do produkcji serów. Dzięki procesom ultrafiltracji użytym do utylizacji i przerobu serwatki można jednak w znaczący sposób zmniejszyć ilość serwatki i odzyskać z niej cenne białko paszowe $\alpha$ - laktoalbuminę, a dodatkowo stosuje się następujące procesy:

- zatężanie serwatki metodą odwróconej osmozy;

- mikrofiltrację serwatki - w celu wstępnego oczyszczenia z tłuszczu i kazeiny;

- nanofiltrację serwatki - w celu jej demineralizacji.

Odcieki tworzące się podczas eksploatacji składowisk odpadów stałych stanowią istotne zagrożenie dla środowiska, szczególnie wodnego. Ich obciążenie zarówno substancjami organicznymi, jak i solami nieorganicznymi, zmienny skład i zmienna objętość powodują, że oczyszczanie odcieków jest znacznie trudniejsze niż oczyszczanie ścieków komunalnych. Obecnie stosuje się do tego celu wiele metod, ale najczęściej technikę odwróconej osmozy.

Kolejnym przykładem na przydatność technik membranowych jest odnowa wody w celu uzyskania wody użytecznej. Odnowa wody oznacza 
zespół procesów jednostkowych doczyszczania ścieków umożliwiających ich wtórne wykorzystywanie jako wody przemysłowej lub ochronę zbiornika przed eutrofizacją. Dotyczy to głównie ścieków doczyszczanych w celu uzyskania wody odnowionej jako wody komunalnej, po usunięciu wielu substancji organicznych, mikroorganizmów i związków biogennych z wysoką efektywnością.

Ścieki powstające w przemyśle włókienniczym i farbiarniach należą do najbardziej uciążliwych, głównie ze względu na ich znaczne obciążenie związkami chemicznymi: detergentami, solami i barwnikami. Do oczyszczenia tych ścieków stosuje się najczęściej membrany dynamiczne z tlenku cyrkonu i z kwasu poliakrylowego. Skuteczną metodą separacji zanieczyszczeń z wody, pozwalającą także na zamknięcie obiegu wody używanej w zakładach włókienniczych i farbiarniach, jest nanofiltracja. Pozostałe po tym procesie skoncentrowane mieszaniny barwników i substancji pomocniczych w ściekach usuwane są za pomocą metod biologicznych. W celu skutecznego i wydajnego zamknięcia obiegu wody w farbiarniach łączy się również techniki membranowe z metodami biologicznymi. Ścieki powstające w wyniku barwienia dzianin po procesie filtracji zostają zawrócone do procesu barwienia różnych tkanin. Natomiast ścieki powstające $\mathrm{w}$ przemyśle papierniczym charakteryzują się dużą ilością zawiesin, rozpuszczonych substancji organicznych i nieorganicznych. Do usunięcia zanieczyszczeń z tych ścieków najczęściej stosuje się technikę ultrafiltracji lub odwróconej osmozy.

Obecność substancji ropopochodnych, na przykład olejów, tłuszczy, smarów występujących w formie zemulgowanej w ściekach emulsyjnych, powoduje znaczące zakłócenie procesów oczyszczania tych ścieków. Obecność olejów utrudnia również uzdatnianie wody, zmniejsza jej przydatność do picia oraz na potrzeby gospodarcze i rekreacji. Klasyczne metody oczyszczania ścieków emulsyjnych są często mało efektywne, dlatego zastosowanie technik membranowych może być $w$ tym przypadku najkorzystniejszym rozwiązaniem, a w szczególności metod elektrochemicznych oraz ciśnieniowych technik membranowych.

Za pomocą membran dynamicznych można także oczyszczać kwaśne pozostałości z rafinerii ropy naftowej, których głównym zanieczyszczeniem jest nafta. Służy do tego technika osmozy odwróconej. Istnieje wtedy możliwość uzyskania wysokiego, bo około 95-procentowego stopnia oddzielenia ciał stałych.

Wzrasta także zainteresowanie tymi procesami w ochronie powietrza, do oczyszczania i rozdzielania mieszanin gazów powietrza, głównie 
do usuwania szczególnie niebezpiecznych dla zdrowia ludzkiego zanieczyszczeń organicznych.

Można wskazać wiele korzyści płynących ze stosowania membran w ochronie środowiska. Przede wszystkim w porównaniu z wieloma innymi tradycyjnymi technikami i procesami, choćby z destylacją, membrany zużywają mniej energii, surowców i personelu obsługującego. Dodatkowo instalacje oparte na przykład na odwróconej osmozie i ultrafiltracji mają prostszą konstrukcję i są łatwiejsze w obsłudze. Należy też podkreślić, że wykorzystanie przez przedsiębiorstwo technik membranowych może przyczynić się do większej produktywności zasobów (głównie wody) oraz zmniejszenia ilości wytwarzanych odpadów stałych i ciekłych w procesie produkcji, a przez to pozwala na uzyskanie wymiernych korzyści ekonomicznych. Woda oczyszczona dzięki procesom membranowym może być bowiem z powrotem zwracana do produkcji.

Reasumując, stosowanie technik membranowych wydaje się uzasadnione ze względu na wiele uwarunkowań, w pierwszej kolejności technicznych i ekonomicznych (ze względu chociażby na stosunkowo małe koszty eksploatacyjne), a także właściwości aplikacyjne. Wprowadzenie do praktyki gospodarczej technik membranowych jest uważane za znaczący krok w dziedzinie ochrony środowiska. Ocenia się także, że technologie te w zastosowaniach związanych z oczyszczaniem wody i ścieków należą obecnie do najlepszych dostępnych technologii i efektywnie przyczyniają się do zrównoważonego rozwoju kraju. Niektóre z nich wymagają stosunkowo wysokich nakładów inwestycyjnych, jednakże obowiązujące regulacje prawne oraz instrumenty ekonomiczne polityki ekologicznej powinny wspierać wykorzystywanie tych technik w praktyce gospodarczej, tak aby kary związane z odprowadzaniem zanieczyszczeń bezpośrednio do środowiska nie były niższe od koniecznych nakładów na ochronę środowiska, w tym nakładów na techniki membranowe.

\section{Literatura}

Biernacka E., Suchecka T., Techniki membranowe w ochronie środowiska, Wydawnictwo SGGW, Warszawa 2004.

Bodzek M., Separacja membranowa w inżynierii środowiska. Podstawy procesów, cz. I-V, "Technologia Wody" nr 1-5/2012.

Bodzek M., Konieczny K., Technologie membranowe w uzdatnianiu wody do picia, [w:] M. Sozański (red.), Zaopatrzenie w wodę, jakość i ochrona wód - zagadnienia współczesne, t. 1, Poznań 2010. 
Chrobot P., Potencjał technologii membranowych w branży wod-kan, "Wodociągi i Kanalizacja", nr 10(140)/2015, s. 52-56.

Gromiec M., Słowik N. (red.), Zastosowanie nowych technologii w sektorze ochrony środowiska, Wydawnictwo NFOŚiGW, Warszawa 2006.

Janosz-Ratajczyk M. (red.), Wybrane procesy jednostkowe w inżynierii środowiska, Wydawnictwo Politechniki Częstochowskiej, Częstochowa 2004.

Kowal A.L., Świderska-Bróż M., Oczyszczanie wody. Podstawy teoretyczne i technologiczne, procesy i urządzenia, Wydawnictwo Naukowe PWN, Warszawa 2009.

Narębska A., Membrany i membranowe techniki rozdziału, Wydawnictwo Uniwersytetu Mikołaja Kopernika, Toruń 1997.

Nawirska-Olszańska A., Procesy membranowe $w$ procesie uzdatniania wody, „Przemysł Spożywczy” 2015, z. 6.

Traczewska T.M. (red.), Interdyscyplinarne zagadnienia $w$ inżynierii $i$ ochronie środowiska: praca zbiorowa, t. 2, Oficyna Wydawnicza Politechniki Wrocławskiej, Wrocław 2012.

Zarzycki R., Imbierowicz M., Stelmachowski M., Wprowadzenie do inżynierii i ochrony środowiska, t. 1: Ochrona środowiska naturalnego, Wydawnictwa Naukowo-Techniczne, Warszawa 2007. 


\section{Rozdział 4}

\section{Technologie środowiskowe}

\subsection{Wprowadzenie}

W okresie transformacji w Polsce został położony duży nacisk na działania w zakresie poprawy stanu środowiska oraz rozwoju wielu sektorów gospodarki w obszarze ochrony środowiska. Działania te w znaczący sposób przyczyniły się także do rozwoju technologii środowiskowych oraz wdrażania innowacyjnych rozwiązań w zakresie organizacji i zarządzania środowiskiem. Wiele z obecnie istniejących technologii jest jednak wciąż niedostatecznie wykorzystywanych. Decyduje o tym wiele czynników, ale do najistotniejszych należy zaliczyć: przywiązanie do istniejących rozwiązań i technologii, sygnały cenowe na rynku promujące systemy mniej przyjazne środowisku, utrudniony dostęp do źródeł finansowania, a także zbyt niska świadomość ekologiczna konsumentów i klientów. Działania na rzecz technologii środowiskowych prowadzące do pełnego wykorzystania potencjału zarówno tych technologii, jak i ekoinnowacji technologicznych stanowią obecnie istotny element wzmocnienia polityki ochrony środowiska oraz polityki innowacyjnej, a tym samym są bardzo istotnym czynnikiem ogólnego wzrostu gospodarczego.

\subsection{Istota technologii środowiskowych}

Technologie środowiskowe, nazywane w literaturze przedmiotu również zielonymi technologiami, technologiami przyjaznymi dla środowiska czy też ekologicznymi, to wszelkie technologie, których użytkowanie przyczynia się do ograniczenia negatywnego wpływu produkcji i usług na środowisko. Według definicji zaczerpniętej z rozdziału 34 Agendy $21^{1}$ „technologie przyjazne dla środowiska chronią środowisko, generują mniej zanieczyszczeń, wykorzystują mniejsze ilości zasobów w bardziej

Agenda 21 (Action Programme - Agenda 21) - dokument przyjęty na konferencji "Środowisko i Rozwój" z inicjatywy ONZ w 1992 roku na II Konferencji w Rio de Janeiro. 
racjonalny sposób, zapewniają powtórne wykorzystanie powstających produktów i odpadów, zapewniają unieszkodliwianie wytwarzanych odpadów w bardziej racjonalny sposób niż technologie, dla których są alternatywami".

Technologie środowiskowe obejmują technologie produkcji (np. „końca rury", tzn. unieszkodliwianie zanieczyszczeń po ich powstaniu), systemy technologiczne, procesy produkcyjne i kontroli zanieczyszczeń, produkty i usługi powodujące mniejszą ilość zanieczyszczeń i zasobooszczędne oraz procedury organizacyjne i zarządzanie (np. zamknięte obiegi wody, kaskadowe wykorzystanie energii lub technologie energooszczędne).

W porównaniu do technologii tradycyjnych stosowanych w podobnych obszarach działalności gospodarczej pozwalają wytwarzać takie same wyroby, oferować takie same usługi czy zapewniać zbliżone potrzeby konsumpcyjne, jednak przy mniejszym oddziaływaniu na środowisko na wszystkich bądź na jednym z etapów "cyklu życia”. Często więc technologie środowiskowe przynoszą redukcję kosztów i dzięki ograniczeniu zużycia energii i surowców - także poprawę konkurencyjności. Powodują zarazem mniejszą emisję zanieczyszczeń i odpadów, ponieważ są procesami produkcji mało- lub bezodpadowymi. Oprócz tego pozwalają na wykorzystywanie zasobów naturalnych w sposób zapewniający ich dłuższą dostępność.

Można wskazać wiele korzyści dla gospodarki i środowiska wynikających ze stosowania rozwiązań technologicznych w zakresie ochrony środowiska. Kluczowe jest to, że sprzyjają one oszczędności materiałów i zasobów naturalnych, ograniczają pobór energii i emisję zanieczyszczeń, umożliwiają wydobywanie bogactw naturalnych z określonych źródeł energii oraz odzysk wartościowych dóbr. Dodatkowo skutecznie przyczyniają się do wzrostu efektywności ekologicznej, umożliwiając produkcję większej ilości dóbr przy wykorzystaniu mniejszej ilości zasobów i tym samym mniejszej szkodliwości dla środowiska przyrodniczego.

\subsection{Strategie i działania w zakresie technologii środowiskowych}

Działania na rzecz technologii środowiskowych stanowią ważny element wzmocnienia polityk w zakresie ochrony środowiska i innowacji. Ich celem jest efektywne wykorzystanie potencjału technologii do realizacji wyzwań ekologicznych, przy jednoczesnym zachowaniu wzrostu gospodarczego i poprawy konkurencyjności. 
W latach 2004-2006 działania Unii Europejskiej na rzecz technologii środowiskowych były realizowane głównie poprzez Plan działań UE na rzecz Technologii Środowiskowych - ETAP. Zasadniczym celem tego planu było efektywne użytkowanie potencjału nowatorskich rozwiązań technologicznych dla wzrostu gospodarczego, w tym promowanie innowacji ekologicznych oraz wdrażania na szerszą skalę technologii środowiskowych. Plan ten znacząco wsparł długofalowy program społeczno-gospodarczy rozwoju UE, szczególnie w odniesieniu do priorytetowych obszarów działań w zakresie technologii przyjaznych środowisku.

Polska włączyła się w proces realizacji ETAP, przyjmując Mapę Drogową Wdrażania Planu Działania na rzecz Technologii Środowiskowych - KETAP, w ramach której w 2005 roku powołana została Polska Plat-

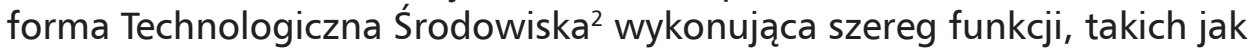
kreowanie wizji sektora oraz ustalanie kryteriów na rzecz rozwoju technologii środowiskowych i ekoinnowacji.

Europa jest od wielu lat światowym liderem ,zielonych" technologii i stanowi jedną trzecią globalnego rynku. Nadal jednak istnieją ogromne możliwości lepszego wykorzystania najnowszych technologii w dziedzinie transportu, energii i zużycia surowców. Firmy europejskie osiągnęły bardzo silną pozycję w wytwarzaniu energii ze źródeł odnawialnych, a także w gospodarce odpadami i recyklingiem. Zielone technologie wykorzystywane są również do gromadzenia informacji o środowisku poprzez monitorowanie i zbieranie danych. Automatyczne stacje pomiarowe zapisują niektóre parametry meteorologiczne, między innymi temperaturę powietrza atmosferycznego czy prędkość wiatru. Jednak żeby w pełni wykorzystać potencjał technologii, wciąż potrzeba większej akceptacji dla tych działań na rynku. Ponadto brak wiedzy o rzeczywistych kosztach pozyskiwania, zużywania i usuwania materiałów oraz wytwarzania i poboru energii nadal stanowi znaczącą barierę w szerszym wdrażaniu wielu innowacji ekologicznych. Kluczową rolę w tym zakresie odgrywa Europejska Agencja Środowiska, która dostarcza wiedzę i umożliwia wymianę informacji na temat technologii środowiskowych. Można stwierdzić, że obecnie Unia Europejska podejmuje wiele inicjatyw i działań, aby stworzyć odpowiednie warunki polityczne do dalszego rozwoju nowoczesnych technologii środowiskowych.

W Polsce z każdym rokiem wzrasta zainteresowanie technologiami ekologicznymi, ponieważ coraz więcej przedsiębiorstw oraz organizacji dostrzega korzyści wynikające $z$ ich stosowania, i to zarówno

2 http://bpk.ietu.katowice.pl/ envitech/ppts/index.php? node=7. 
dla gospodarki, jak i środowiska. W krajowym dokumencie Średniookresowa Strategia Rozwoju Kraju 2020. Aktywne społeczeństwo, konkurencyjna gospodarka, sprawne państwo ${ }^{3}$ wśród priorytetów wskazuje się między innymi na konieczność wzrostu produktywności gospodarki. Proponuje się w tym względzie dalszy rozwój nowoczesnych sektorów przemysłu wykorzystujących zaawansowane technologie, a także przeprowadzenie zmian w gospodarce, które umożliwią sprawne adaptowanie najbardziej produktywnych technologii światowych oraz wdrażanie krajowych innowacji. Rozwój technologii przyjaznych środowisku, w tym ekoinnowacji technologicznych, może w znacznym stopniu przyczynić się do realizacji tak zdefiniowanych priorytetów. Strategie sektorowe, takie jak Bezpieczeństwo Energetyczne i Środowisko ${ }^{4}$ czy Strategia innowacyjności i efektywności gospodarki ${ }^{5}$ obejmują podobne cele i kierunki działań. Takie ukierunkowanie polityki rozwojowej państwa wydaje się w pełni uzasadnione, ponieważ w znacznym stopniu opiera się na silnym sektorze technologii oraz innowacji ekologicznych.

Działania na rzecz rozwoju i wdrażania ekotechnologii w Polsce można podzielić na osiem podstawowych grup. Po pierwsze, jest to skoncentrowanie badań naukowych i prac rozwojowych na rozwoju tych technologii oraz następnie ich realizacji w formie projektów badawczych zamawianych. Po drugie, monitorowanie rozwoju i wdrożeń poprzez ocenę prac badawczych oraz stopnia ich wykorzystania, przede wszystkim w przemyśle. Kolejna grupa dotyczy weryfikacji i certyfikacji technologii, czyli przygotowania i stosowania przejrzystych kryteriów oceny, tzw. kryteriów środowiskowych i certyfikacji. Czwartą grupę tworzą działania związane z wyznaczonymi celami środowiskowymi. Jest to instrument możliwy do stosowania na każdym szczeblu programowania polityki środowiskowej, z uwzględnieniem harmonizacji przepisów prawnych. Do piątej grupy należy zaliczyć „zielone” zamówienia publiczne. Szósta grupa w klasyfikacji działań obejmuje koncentrowanie środków finansowych i oznacza tworzenie warunków, między innymi przez podejmowanie partnerskich inicjatyw przemysłu i środowiska naukowo-badawczego (np. poprzez platformy technologiczne środowiska), a także

3 http://www.fundusze.uj.edu.pl/documents/31275205/3ab2c864-e5fc-494b-8c23-0 a1603852a81.

4 http://bip.mg.gov.pl/node/21165.

5 http://www.mg.gov.pl/Wsparcie+ przedsiebiorczosci/Polityki+ przedsiebiorczosci + $\mathrm{i}+$ innowacyjnosci/Polityka+przedsiebiorczosci/Strategia + Innowacyjnosci+i+Efektyw nosci+Gospodarki. 
mechanizmów finansowych umożliwiających realizację inwestycji w rozwiązania techniczne o charakterze środowiskowym (w ramach programów operacyjnych), ze szczególnym uwzględnieniem zasad partnerstwa publiczno-prywatnego oraz form wspierania działalności innowacyjnej, takich jak kredyt technologiczny. Siódma grupa odnosi się do czynników rynkowych i fiskalnych i proponuje wprowadzenie rozwiązań ekonomicznych sprzyjających rozwojowi ekotechnologii. Natomiast ostatnia grupa, ósma, nakierowana jest na promocję i upowszechnianie informacji dotyczących technologii środowiskowych.

Wśród kluczowych polskich instrumentów rządowych promujących technologie środowiskowe i ekoinnowacje technologiczne należy wyróżnić GreenEvo Akcelerator Zielonych Technologii (AZT) ${ }^{6}$. Jest to inicjatywa Ministerstwa Środowiska wspierająca wejście polskich ekoinnowatorów z polskimi zielonymi technologiami na globalny rynek, powołana w 2008 roku i skierowana do firm z sektora małych i średnich przedsiębiorstw. Program dotyczy zaawansowanych technologii ochrony środowiska, sprawdzonych, skomercjalizowanych i wdrożonych na rynku, a także posiadających potencjał do transferu i szansę na dalszy rozwój. Zakres zielonych technologii propagowanych przez GreenEvo odnosi się między innymi do ochrony powietrza, ochrony bioróżnorodności, gospodarki wodno- ściekowej, gospodarki odpadami, budownictwa pasywnego, oszczędności energii, odnawialnych źródeł energii oraz przetwarzania biomasy.

Dotychczas odbyło się sześć edycji tego programu, w trakcie których wybrano łącznie 74 technologie polskich producentów wspierające ochronę środowiska i klimatu. Ważnym bodźcem dalszego rozwoju tych technologii jest pomoc instytucjonalna i finansowa, w tym pomoc w kontaktach zagranicznych oferowana wybranym w procedurze konkursowej rozwiązaniom technologicznym. Należy w tym miejscu zaznaczyć, że choć w Polsce realizowane są przedsięwzięcia związane z ochroną środowiska, to jednak wciąż większość nowoczesnych technologii stosowanych w naszym kraju powstaje za granicą. Pomimo sukcesów programu GreenEvo można wskazać wiele barier w tej dziedzinie, na przykład niedofinansowanie technicznych ośrodków naukowych, brak odpowiedniego wsparcia dla etapów wdrożenia i brak odpowiedniego zaplecza technicznego przedsiębiorstw, które mogą powodować dalsze pogłębianie marginalizacji polskiego rynku nowoczesnych technik ochrony środowiska.

6 http://greenevo.gov.pl/ 
Podsumowując, polskie zielone technologie to innowacyjne rozwiązania posiadające znaczący potencjał dalszego rozwoju. Są one często tańsze od zagranicznych, cechuje je wysoka jakość, a wiele z nich nie posiada odpowiedników na rynku europejskim. Projekt GreenEvo, pokazując najlepsze krajowe innowacyjne technologie środowiskowe, udowadnia, że Polska posiada potencjał technologiczny, który z powodzeniem można oferować na światowym rynku.

\subsection{System weryfikacji technologii środowiskowych}

Dużym problemem polskich firm z branży technologii środowiskowych są małe szanse na wypromowanie swoich rozwiązań za granicą. Stworzenie i rozwój Systemu Weryfikacji Technologii Środowiskowych (ETV) oraz opracowanie Krajowego Systemu Monitorowania Technologii Środowiskowych mogą znacznie poprawić sytuację polskich przedsiębiorstw technologicznych oraz przyczynić się do pobudzenia innowacyjności.

ETV jest narzędziem rynkowym, które ma za zadanie ułatwić i przyspieszyć komercjalizację innowacyjnych technologii środowiskowych. W ramach ETV przeprowadzana jest weryfikacja, która odnosi się do projektu technicznego danej technologii. Przyjęto dwa główne obszary weryfikacji. W zakresie materiałów, odpadów i zasobów są to:

- recykling przemysłowych produktów ubocznych i odpadów;

- recykling odpadów budowlanych;

- separacja lub techniki sortowania odpadów stałych, odzysk surowców;

- recykling baterii, akumulatorów i substancji chemicznych.

Natomiast technologie energetyczne obejmują:

- produkcję energii elektrycznej i cieplnej z odnawialnych źródeł energii;

- wykorzystanie energii z odpadów;

- technologie wydajne energetycznie, np. mikroturbiny, wodór i ogniwa paliwowe, pompy ciepła, skojarzona produkcja ciepła i energii, logistyka;

- magazynowanie i odzysk energii. 
Krajowy System Monitorowania Technologii Środowiskowych (KSMTŚ) jest formą wspierania technologicznej ekoinnowacyjności w Polsce, zgodnie z potrzebami gospodarki, przy maksymalnym wykorzystaniu potencjału $B+R$ oraz środków publicznych i prywatnych. Celem systemu jest określenie, a następnie monitorowanie kierunków i tempa rozwoju technologii środowiskowych w Polsce w poszczególnych kategoriach technologii środowiskowych ustanowionych na podstawie docelowych efektów ekologicznych. Wyróżnia się kilka aspektów monitorowania, takich jak:

- ekoinnowacyjność rozwiązań oparta na wydajności ekologicznej;

- nakłady na badania, rozwój i wdrożenia technologii środowiskowych;

- potencjał badań i rozwoju technologii środowiskowych;

- przydatność rozwijanych technologii w praktycznym zastosowaniu.

Do kategorii technologii środowiskowych, czyli obszarów tematycznych monitorowania, należą: czyste procesy, materiały i produkty, efektywne wykorzystanie energii i oszczędność energii, produkcja czystej energii, recykling, gospodarka odpadami, gospodarka wodna i ściekowa, kontrola zanieczyszczeń powietrza, ochrona gleby i krajobrazu, redukcja hałasu, działania o charakterze przekrojowym (edukacja, konsulting, upowszechnianie informacji, sieci itp.).

Natomiast podstawowe kryteria ekoinnowacyjności oparte na wydajności ekologicznej dla każdej z kategorii technologii środowiskowych obejmują: zużycie energii, wody i surowców, emisje do środowiska gazów cieplarnianych, substancji zubażających warstwę ozonową i substancji zakwaszających, a także całkowity odpad, w tym bilans odpadów i odpad wytwarzany. Główne korzyści z przeprowadzonej weryfikacji to miedzy innymi:

- minimalizacja kosztów badań technologii;

- skuteczniejszy proces wprowadzania innowacyjnej technologii na rynek;

- wyeliminowane ryzyko technologiczne związane z wdrożeniem; 
- dowód spełniania przez technologię wymagań wynikających z przepisów prawnych;

- dokumentacja potwierdzająca informacje o sprawności technologii (zawarta np. w ofercie przetargowej w zamówieniach publicznych).

System weryfikacji technologii środowiskowych jest systemem dobrowolnym, który pozwala udokumentować - opierając się na podstawach naukowych - wiarygodność technologii oraz fakt, że uzyskuje ona deklarowane parametry i wynikający z nich efekt ekologiczny. Jeśli firma dysponuje innowacyjną technologią, jest jej autorem, ma jednak problem z jej wdrożeniem na rynek, może zgłosić się do Polskiej Jednostki Weryfikującej Technologie Środowiskowe. Obecnie istnieje możliwość uzyskania przez przedsiębiorstwo świadectwa weryfikacji technologii w obszarze odpadów i technologii środowiskowych, które jest respektowane przez wszystkie kraje Europy. Może ono pomóc firmie w pozyskiwaniu klientów oraz funkcjonowaniu na rynku polskim i zagranicznym, a także świadczyć o profesjonalnie budowanej pozycji rynkowej.

Podkreślając znaczącą rolę ETV w rozwoju polskich technologii środowiskowych, trzeba przyznać, że bardzo ważne jest odpowiednie wsparcie na szczeblu krajowym badań naukowych, innowacyjności i ułatwień dla wdrażania nowych technologii w sektorze ochrony środowiska, a jednocześnie podejmowanie działań modernizujących krajową bazę naukową w zakresie inżynierii środowiska.

\subsection{Obszary zastosowania technologii środowiskowych}

Do priorytetowych obszarów zastosowania technologii środowiskowych o największym znaczeniu dla środowiska obecnie oraz w perspektywie długookresowej należą: pozyskiwanie surowców i nośników energii, ochrona powietrza i zapobieganie zmianom klimatu oraz ochrona wód i gleb. Zrównoważone: konsumpcja, systemy logistyczne oraz utylizacja odpadów to $w$ ostatnim czasie obszary technologii o rosnącym znaczeniu.

Technologie środowiskowe stosuje się dzisiaj w wielu sektorach i gałęziach gospodarki, przede wszystkim w gospodarce odpadami i wodno-ściekowej, budownictwie ekologicznym, w energetyce, ograniczaniu emisji hałasu oraz w usługach konsultingowych. Można stwierdzić, 
że stosowanie technologii środowiskowych jest możliwe we wszystkich sektorach gospodarki. W związku z tym stan rozwoju technologii ochrony środowiska w danym kraju ocenia się najczęściej w odniesieniu do ochrony zasobów wodnych, gleb, powietrza i klimatu, a także zrównoważonej produkcji i konsumpcji. Warto przyjrzeć się bliżej niektórym z wymienionych wyżej obszarów zastosowania zielonych technologii.

W ostatnim dziesięcioleciu nastąpił w krajach UE szczególnie silny rozwój technologii ochrony powietrza i przeciwdziałających powstawaniu globalnych zmian klimatu. Na pierwszym miejscu promuje się stosowanie technologii ograniczających emisje z procesów wytwarzania energii elektrycznej i ciepła, urządzeń oczyszczających oraz technologii energooszczędnych. Druga ważna grupa technologii wykorzystywanych w celu ochrony powietrza dotyczy tworzenia wysokosprawnych, tzw. czystych technologii wytwarzania energii elektrycznej w elektrowniach kondensacyjnych poprzez spalanie paliw węglowych o wyższych parametrach jakościowych, jak również w kotłach fluidalnych cyrkulacyjnych z wysokosprawnym usuwaniem gazów o odczynie kwasowym.

W przypadku ochrony zasobów wód proponuje się wiele technologii, które przyczyniają się do kształtowania i ochrony tych zasobów, zrównoważonego korzystania z wód oraz zarządzania zasobami wodnymi, ukierunkowanych na ograniczanie ładunków zanieczyszczeń ze źródeł punktowych i przestrzennych. Są to więc przede wszystkim technologie związane z bardziej efektywnym oczyszczaniem ścieków przemysłowych i komunalnych, a także z procesami zagęszczania i odwadniania osadów ściekowych. W sektorze gospodarki wodno-ściekowej ma zastosowanie wiele rodzajów zielonych technologii - od technik oczyszczania wody po technologie ściekowe. Przykładem może być wykorzystanie nowych metod bezwykopowych przy budowie kanalizacji lub renowacji istniejących rurociągów, metod biologicznego usuwania azotanów w procesach uzdatniania wody pitnej czy wprowadzanie ekologicznych przydomowych oczyszczalni ścieków. W zakresie oczyszczania ścieków problemem pozostają nadal zagospodarowanie osadów ściekowych i maksymalna redukcja ich objętości. Ilość osadów ściekowych znacznie wzrosła w ostatnich latach ze względu na budowę systemów kanalizacyjnych oraz nowych oczyszczalni ścieków. Coraz częściej stosowaną technologią ostatecznego zagospodarowania osadów i znacznego zredukowania ich objętości jest obecnie suszenie i spalanie. Konieczny wydaje się jednak także dalszy rozwój technologii beztlenowej stabilizacji osadów, ponieważ w efekcie można uzyskać większą produkcję biogazu (a tym 
samym odzyskać energię z osadów) i jednocześnie wyższy stopień redukcji związków organicznych.

Technologie ochrony gleb to obecnie przede wszystkim technologie polegające na stabilizacji zanieczyszczeń w wierzchniej warstwie gleby, z użyciem specjalnie dobranych gatunków roślin uprawianych na uprzednio kondycjonowanym podłożu. Niestety ze względu na znaczne koszty kluczowy dla ochrony gleb proces remediacji zarówno powierzchni, jak i głębszych warstw gruntu wciąż jest w Polsce zbyt rzadko stosowany.

W dziedzinie gospodarki odpadami priorytetem w krajach UE jest ograniczenie ilości odpadów kierowanych bezpośrednio na składowisko, z jednoczesnym ponownym wykorzystaniem surowców wtórnych. W tym przypadku najlepszy efekt ekologiczny można uzyskać między innymi przez wykorzystanie odpowiednich technik już na etapie sortowania odpadów, w procesach recyklingu i odzysku z odpadów materiałów użytecznych, racjonalnego składowania odpadów i zarządzania przepływem surowców. Sektor gospodarki odpadami obejmuje także technologie środowiskowe w zakresie efektywnego i zrównoważonego zagospodarowania odpadów biodegradowalnych oraz nowoczesne instalacje do przetwarzania odpadów.

W sektorze energetycznym w ostatnich latach najbardziej rozwijają się technologie środowiskowe wytwarzania energii ze źródeł odnawialnych, w tym technologie uprawy i wykorzystania roślin energetycznych oraz produkcji zrąbków, pelet czy brykietu drzewnego. Rozwijają się także technologie pozwalające na kojarzenie wysokosprawnego wytwarzania energii elektrycznej i ciepła zarówno w dużych, jak i małych instalacjach energetycznych.

Technologie środowiskowe zapewniające zrównoważoną produkcję i konsumpcję, których intensywny rozwój można zaobserwować w ostatnich latach, to przede wszystkim czyste technologie produkcyjne, opierające się na efektywnym wykorzystywaniu zasobów i eliminowaniu wytwarzania zanieczyszczeń. To także technologie surowcowe, czyli technologie eksploatacji podstawowych paliw stosowanych w górnictwie węgla kamiennego i brunatnego, w górnictwie naftowym i gazownictwie, przy wydobywaniu rud miedzi, siarki, soli kamiennej i innych surowców mineralnych.

Postęp w dziedzinie technologii środowiskowych zauważalny jest nie tylko w krajach członkowskich UE, ale w skali globalnej. Przewiduje się, że do roku 2020 będzie widoczny dalszy jego wzrost, szczególnie 
na polu technologii fizykochemicznych i bioinżynieryjnych, związanych z inżynierią materiałową oraz technologii usuwania substancji problemowych ze środowiska gruntowego, wodnego i ze ścieków. Obszary wdrażania ekotechnologii w ramach obecnych i perspektywicznych kierunków działania inżynierii środowiska to także miasta, fabryki i mobilność jutra, które scharakteryzowano poniżej.

„Miasta jutra" to między innymi planowanie urbanistyczne mające na celu redukcję zużycia energii i surowców naturalnych, działania związane ze zmianami klimatycznymi oraz wiele innych nowych aktywności opartych na ekotechnologiach. Należy podkreślić, że ekologiczny rozwój miast wymaga strategii rozwoju i wdrażania innowacji technologicznych i społecznych, które muszą być opracowane w odniesieniu do ogólnego rozwoju przestrzeni miejskiej. W zielonych miastach przyszłości w planowaniu i budownictwie integruje się bowiem aspekty kulturowe, ekonomiczne, społeczne i ekologiczne. Są to także miasta o dużej efektywności energetycznej i znacznym współczynniku wykorzystywania energii odnawialnej, niewielkich emisjach dwutlenku węgla, miasta o zrównoważonym, czystym, łatwo dostępnym, efektywnym i tanim transporcie, dobrej infrastrukturze rowerowej i pieszej. Miasta przyszłości uwzględniają więc wszystkie wymiary zrównoważonego rozwoju. Innowacyjne technologie środowiskowe umożliwiają pogodzenie działalności gospodarczej i wzrostu z względami kulturowymi, społecznymi i środowiskowymi, a także miejskiego stylu życia z możliwościami ekologicznymi.

„Fabryki jutra" to firmy przyszłości, których procesy produkcyjne nie będą mieć wcale wpływu (lub jedynie znikomy wpływ) na środowisko naturalne oraz zmiany klimatyczne. To firmy wysokiej efektywności dzięki zastosowaniu optymalnych rozwiązań ergonomicznych. To działania oparte na nowych, efektywnych ekoprocesach redukujących zużycie energii i surowców naturalnych.

"Mobilność jutra" dotyczy mobilności ludzi oraz towarów i jest jednym z kluczowych czynników osiągnięcia wskaźników ekonomicznych oraz środowiskowych w zakresie zrównoważonego transportu i logistyki. Wśród wielu wyzwań, które należy podjąć w celu rozwiązania przyszłych problemów mających wpływ na mobilność, można wskazać między innymi wdrożenie inteligentnych ekologicznych rozwiązań inżynieryjnych w zakresie transportu i logistyki. Dynamiczny rozwój transportu jest bowiem jednym z kluczowych czynników rozwoju gospodarczego świata, a przy tym transport to największe źródło zanieczyszczeń powietrza. Dlatego też unijna polityka rozwojowa w perspektywie 2020 roku 
ukierunkowana jest na transport zasobooszczędny i ekologiczny, a równocześnie szybki i tani. „Zielone” technologie wprowadzane w środkach transportu cieszą się coraz większym powodzeniem wśród konsumentów na całym świecie. Przykładem mogą być tu samochody hybrydowe, które wytwarzają mniejszą ilość zanieczyszczeń, są energooszczędne i stosunkowo ciche.

\section{Literatura}

Bendyk E., Bonikowska M., Rabiej P., Romański W., Energia nowego miasta. Przyszłość miast. Miasta przyszłości. Strategie i wyzwania innowacyjne, społeczne i technologiczne, Raport ThinkTank, Warszawa 2013.

Berger R., Zielony wzrost, zielony zysk. Jak zielona rewolucja stymuluje gospodarkę, Wolters Kluwer Polska, Warszawa 2011.

Chmielniak T., Technologie energetyczne, WNT, Warszawa 2014.

Długosz J., Nowoczesne technologie w logistyce, Polskie Wydawnictwo Ekonomiczne, Warszawa 2009.

Jeż M., Technologie ochrony środowiska. Ochrona atmosfery, WSEiZ, Warszawa 2009.

Komunikat Komisji Wspólnot Europejskich, Stymulowanie technologii w kierunku zrównoważonego rozwoju: Plan Działań Unii Europejskiej w zakresie technologii środowiskowych - ETAP, COM(2004)38 wersja ostateczna, 28 stycznia 2004.

Komunikat Komisji Wspólnot Europejskich, Sprawozdanie z realizacji Planu działań na rzecz technologii dla środowiska (2005-2006), COM(2007)162 wersja ostateczna.

Kulisewicz T., Miasto jako ekosystem, http://inteligentnemiasta.pl/miasto-jako-ekosystem/5368/ (dostęp: 6.11.2015).

"Mapa Drogowa" Wdrażania Planu Działań na rzecz Technologii Środowiskowych w Polsce - KETAP, Ministerstwo Środowiska, Warszawa 2006.

Program Wykonawczy do Krajowego Planu Działań na rzecz Technologii Środowiskowych na lata 2007-2009 z uwzględnieniem perspektywy na lata 2010-2012, Ministerstwo Środowiska, Warszawa 2007.

Średniookresowa Strategia Rozwoju Kraju 2020. Aktywne społeczeństwo, konkurencyjna gospodarka, sprawne państwo, Ministerstwo Rozwoju Regionalnego, Warszawa 2012.

Rynek Polskich Technologii Środowiskowych, http://www.pi.gov.pl/PARPFiles/ file/Raport_tech_srod_final_word.pdf (dostęp: 6.11.2015).

Urbaniak A., Zak̄rzewski P., Inteligentne systemy w inżynierii $i$ ochronie środowiska, Wydawnictwo PZITS, Oddział Wielkopolski, Poznań 2007.

http://www.zielonetechnologie.pl/.

http://www.earthday.org/greencities/cities-of-the-future/. 
http://greenevo.gov.pl/

http://bip.mg.gov.pl/node/21165.

http://www.mg.gov.pl/Wsparcie+ przedsiebiorczosci/Polityki + przedsiebiorczosci+i+innowacyjnosci/Polityka+ przedsiebiorczosci/Strategia+Innowacyjno sci+i+Efektywnosci+Gospodarki.

http://bpk.ietu.katowice.pl/ envitech/ppts/index.php?node $=7$.

http://www.fundusze.uj.edu.pl/documents/31275205/3ab2c864-e5fc-494b8c23-0a1603852a81. 


\section{Rozdział 5}

\section{Innowacyjne technologie środowiskowe Ekoinnowacje technologiczne}

\subsection{Pojęcia wprowadzające}

$\mathrm{Na}$ wstępie rozważań na temat innowacyjnych technologii środowiskowych należy wyjaśnić kilka kluczowych pojęć związanych z tą tematyką. Według ustawy Prawo ochrony środowiska "technika" oznacza zarówno stosowaną technologię, jak i sposób, w jaki dana instalacja jest projektowana, wykonywana, eksploatowana oraz likwidowana. „Dostępne techniki" to techniki o takim stopniu rozwoju, który umożliwia ich praktyczne zastosowanie w danej dziedzinie przemysłu, z uwzględnieniem warunków ekonomicznych i technicznych oraz rachunku kosztów inwestycyjnych i korzyści dla środowiska, a które to techniki prowadzący daną działalność może uzyskać.

Z kolei "czystsza produkcja i czystsze techniki” to działania techniczno-organizacyjne mające na celu eliminację lub zmniejszenie szkodliwego oddziaływania produktu lub procesu wytwórczego na ludzi i środowisko naturalne. Działania te obejmują odpady, surowce, materiały i energię. Czystsza produkcja to stałe stosowanie zintegrowanej strategii zapobiegania zanieczyszczeniu środowiska naturalnego w odniesieniu zarówno do procesów wytwarzania, jak i stosowania produktu. Techniki czystszej produkcji obejmują ochronę zasobów surowców i energii, eliminację surowców toksycznych oraz redukcję ilości i zmniejszenie toksyczności wszystkich typów odpadów.

Pojęcie „najlepsza technika” oznacza najbardziej efektywną technikę w osiąganiu wysokiego ogólnego poziomu ochrony środowiska jako całości. Natomiast najlepsza dostępna technika (BAT) to najbardziej efektywny oraz zaawansowany poziom rozwoju technologii i metod prowadzenia danej działalności, wykorzystywany jako podstawa ustalania granicznych wielkości emisyjnych, które mają na celu eliminowanie i ograniczanie emisji i ich wpływu na środowisko. Zasada stosowania BAT

Prawo ochrony środowiska (Dz.U. z 2006 r. Nr 129, poz. 902). 
jest jedną z zasad polityki ekologicznej, a jej wdrażanie następuje przez instrumenty prawne oraz inne mechanizmy działania, jak na przykład systemy zarządzania środowiskowego.

Zrównoważony rozwój społeczno-gospodarczy kraju oparty jest w znacznej mierze na rozwoju nowych technologii, charakteryzujących się wysokim poziomem innowacyjności i przyjaznych dla środowiska naturalnego. Wykorzystując nowe i jednocześnie najlepsze dostępne technologie, w tym zielone technologie, można uzyskać pożądany efekt ekologiczny w każdym sektorze gospodarki.

\subsection{Produkcja biogazu}

Wśród wielu technologii środowiskowych stosowanych w inżynierii środowiska na uwagę zasługuje produkcja biogazu. Zainteresowanie biogazem wzrasta w wielu krajach, głównie ze względu na ogólny trend w UE w zakresie wykorzystania odnawialnych źródeł energii w ogólnym bilansie energetycznym.

Produkcja biogazu opiera się na procesie fermentacji metanowej. Jest to złożony, wieloetapowy proces biologiczny, pozwalający na pełną lub częściową mineralizację znacznej liczby związków organicznych. Przebiega w warunkach beztlenowych z udziałem kilku grup współpracujących bakterii i jest związany z przyrostem biomasy mikroorganizmów biorących udział w procesie. Procesy podstawowe w fermentacji to przekształcenie związków organicznych o różnym stopniu utlenienia do gazowych produktów końcowych, głównie metanu i dwutlenku węgla, z wytworzeniem produktów pośrednich, takich jak alkohole czy kwasy tłuszczowe. Pewna grupa związków organicznych pozostaje w środowisku, gdyż jest nierozkładalna, nie ulega przekształceniom do produktów końcowych lub jest przekształcana w niewielkim tylko stopniu. Fermentacja metanowa może przebiegać w warunkach naturalnych, wówczas substratami wyjściowymi są głównie muły i osady denne, jak i w specjalnych urządzeniach technologicznych, na przykład komorach fermentacyjnych.

Substraty podlegające fermentacji metanowej mogą charakteryzować się różnorodnymi właściwościami. Ogólnie można je podzielić na takie, które zawierają znaczne ilości nierozpuszczalnych zawiesin organicznych oraz zawierające niewielkie ich ilości. Substratami są głównie poprodukcyjne wody odpadowe oraz inne uciążliwe odpady organiczne.

Obecnie fermentacja metanowa odgrywa nie tylko znaczącą rolę jako metoda utylizacji uciążliwych odpadów organicznych, ale jest także 
innowacyjnym sposobem pozwalającym na pozyskiwanie energii elektrycznej i cieplnej. Wykorzystuje się ją przede wszystkim do przerobu osadów powstających podczas tlenowego oczyszczania ścieków miejskich (rys. 5.1), odpadów z rolnictwa (np. obornik), odpadów i ścieków z przetwórstwa rolno-spożywczego, a także do przerobu organicznej frakcji stałych odpadów komunalnych czy roślin energetycznych (np. kukurydzy).

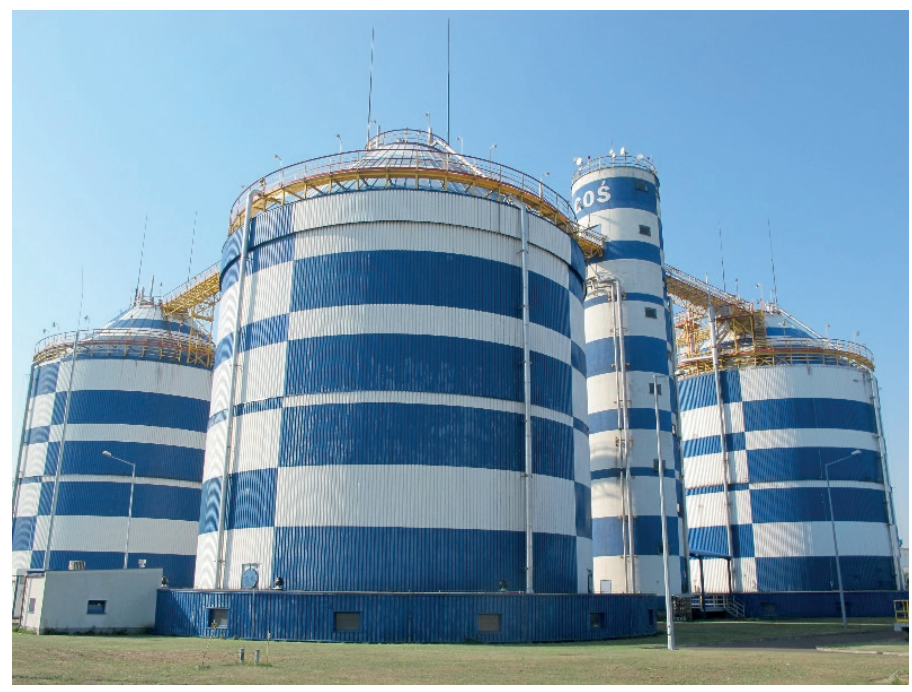

Rys. 5.1. Komory fermentacyjne osadów ściekowych

Źródło: Archiwum Grupowej Oczyszczalni Ścieków w Łodzi Sp. z o. o.

Powstały w procesie fermentacji metanowej główny produkt - biogaz - gromadzony jest w specjalnych zbiornikach (rys. 5.2). Jest to gaz palny, cięższy od powietrza. Niezależnie od rodzaju i struktury substratu obecne są w nim zawsze dwa składniki: metan $\left(\mathrm{CH}_{4}\right)$ i tlenek węgla IV $\left(\mathrm{CO}_{2}\right)$.

Jednak skład morfologiczny substratu przeznaczonego do fermentacji metanowej ma istotny wpływ na ilość wytwarzanego biogazu i zawartość w nim $\mathrm{CH}_{4}$ oraz $\mathrm{CO}_{2}$. Oprócz tych dwóch gazów biogaz zawiera także niewielkie ilości wodoru, siarkowodoru $\left(\mathrm{H}_{2} \mathrm{~S}\right)$ oraz lotne związki organiczne. Sporadycznie może się w nim pojawić również rtęć, ze względu na wysoką prężność jej par. Zawartość $\mathrm{H}_{2} \mathrm{~S}$ w biogazie zależy od zawartości siarczanów (IV), siarczanów (VI) i tiosiarczanów w dopływie. Maksymalną granicą hamującą produkcję metanu jest zawartość $6 \% \mathrm{H}_{2} \mathrm{~S}$ 
w gazie fermentacyjnym. Dobre wyniki neutralizacji niekorzystnego wpływu $\mathrm{H}_{2} \mathrm{~S}$ można osiągnąć przez utrzymanie pH środowiska powyżej 6.

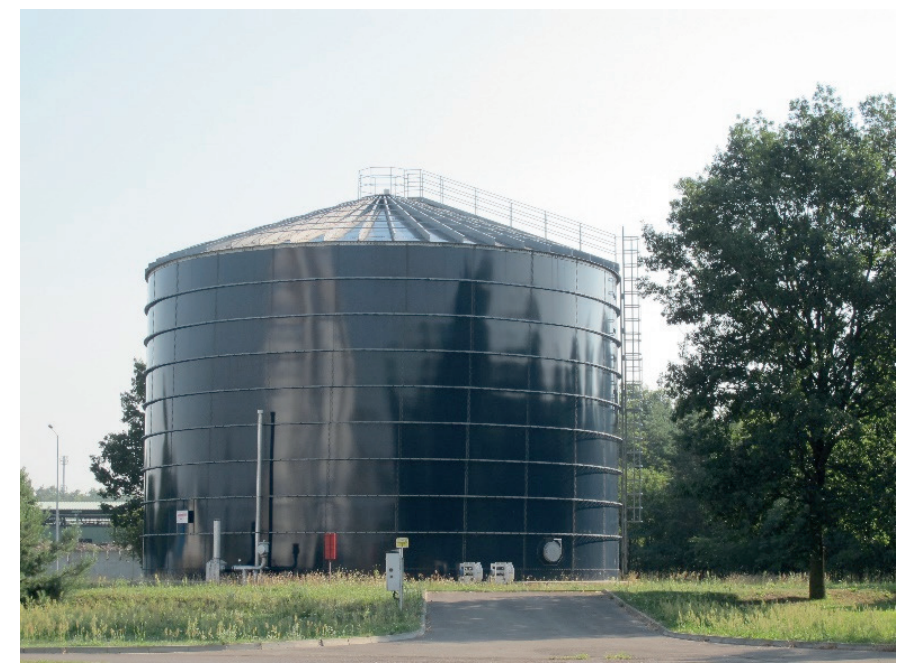

Rys. 5.2. Zbiornik biogazu

Źródło: Archiwum Grupowej Oczyszczalni Ścieków w Łodzi Sp. z o. o.

Wartość opałowa biogazu związana jest z zawartością w $\operatorname{nim} \mathrm{CH}_{4}$ i wynosi średnio około $20000 \mathrm{~kJ} / \mathrm{m}^{3}$. Może być on wykorzystany do produkcji energii cieplnej i elektrycznej (rys. 5.3). Najwięcej biogazu powstaje z rozkładu tłuszczów, natomiast wyższą zawartość $\mathrm{CH}_{4}$ w biogazie można stwierdzić, gdy substratem procesu fermentacji metanowej są białka.

Produkcja biogazu w biogazowni rolniczej może być prowadzona w różnych technologiach. Dobór metody zależy od stosowanych substratów i rozwiązań konstrukcyjnych. Fermentacja metanowa może przebiegać $w$ zakresie temperatur od 4 do $70^{\circ} \mathrm{C}$. Jeśli proces jest prowadzony w temperaturach $30-42^{\circ} \mathrm{C}$, wówczas nazywany jest w literaturze przedmiotu fermentacją mezofilową. Natomiast w zakresie temperatur od 50 do $55^{\circ} \mathrm{C}$ prowadzony jest proces fermentacji termofitowej, który charakteryzuje się większą czułością na zmiany w układzie reagentów i wymaga właściwego doboru wielu czynników i elementów (np. odpowiednich urządzeń, instalacji, konstrukcji zbiorników, materiału wsadowego, a także dobrej izolacji termicznej zbiorników fermentacyjnych). Dotychczas w Polsce wykonano kilka biogazowni działających w zakresie temperatur termofitowych i technologia ta ma duże szanse na dalszy rozwój. 


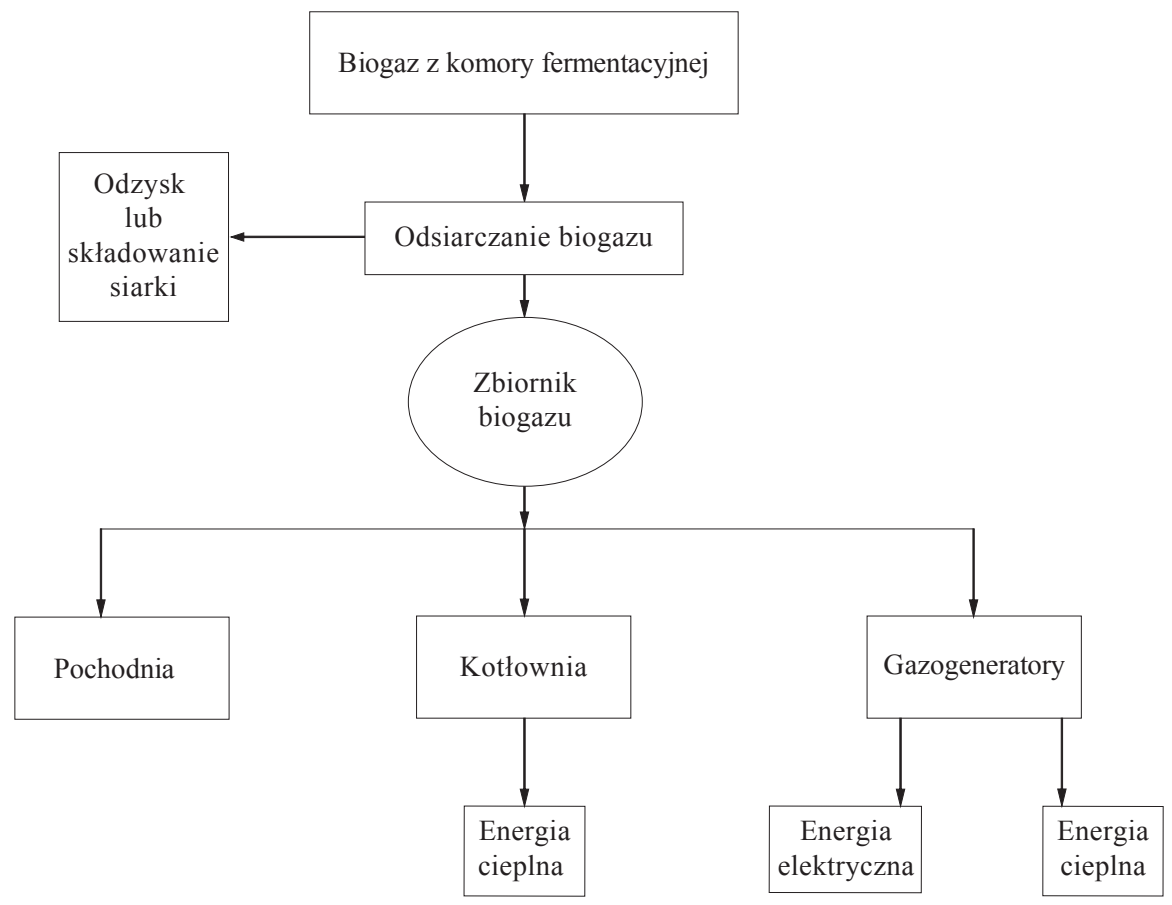

Rys. 5.3. Schemat przykładowego wykorzystania biogazu

Źródło: opracowanie własne na podstawie literatury przedmiotu

Budowa biogazowni musi mieć swoje uzasadnienie ekonomiczne. Rentowność przedsięwzięcia jest uzależniona od szeregu czynników ekonomicznych, prawnych i biotechnologicznych. Przede wszystkim konieczna jest pewność, że na bazie dostępnych odpadów będzie można utrzymać proces na stabilnym i wysokowydajnym poziomie. Ważne są także właściwy dobór warunków fermentacji i ciągła kontrola wielu parametrów, które zapewnią stabilność procesu oraz zadowalającą szybkość i wydajność produkcji biogazu.

\subsection{Bezwykopowe technologie budowy i odnowy rurociągów}

Techniki bezwykopowe opierają się na coraz bardziej zawansowanych technologiach i szybko rozszerza się zakres inwestycji, w których są stosowane. Do niedawna były one wykorzystywane głównie do budowy przewodów podziemnych pod przeszkodami terenowymi oraz na znacznych 
głębokościach. Obecnie są stosowane coraz szerzej, szczególnie w miastach, nie powodując utrudnień w ruchu ulicznym. Są one bardzo atrakcyjne pod względem środowiskowym.

W literaturze przedmiotu proponowany jest podział bezwykopowych technologii budowy i odnowy rurociągów podziemnych według różnych kryteriów. W zależności od zasad urabiania gruntu istnieją technologie: bez wybierania gruntu oraz z wybieraniem gruntu. Istnieje także ogólny podział technologii bezwykopowych w zależności od wymiarów przewodu na technologie dla małych średnic (bez wybierania gruntu) oraz technologie dla dużych średnic ( $z$ wybieraniem gruntu). Obie technologie mogą być stosowane bez możliwości sterowania i kontroli przebiegu trasy oraz z możliwością sterowania. Dodatkowo każda z tych metod może być wykonana kilkoma różnymi technikami. Metody budowy bez możliwości sterowania i kontroli przebiegu trasy są metodami najstarszymi, najprostszymi technologicznie i są stosunkowo tanie. W metodzie budowy z możliwością sterowania i kontroli sterowanie umożliwia korektę przebiegu trasy wprowadzanego przewodu w płaszczyźnie pionowej i poziomej. Istnieją także systemy sterowania z lokalizacją położenia. Metody budowy bez wybierania gruntu dotyczą przeważnie przewodów o średnicach nieprzekraczających $250 \mathrm{~mm}$.

Według najczęściej stosowanej klasyfikacji technologii odnowy przewodów - w zależności od rodzaju uszkodzenia - dzielimy je na: naprawy, renowacje, rekonstrukcje oraz wymiany. Naprawa to zespół doraźnych działań technicznych mających na celu likwidację pojedynczych, drobnych uszkodzeń, które powstały zazwyczaj w wyniku losowych oddziaływań zewnętrznych o intensywności przekraczającej projektowane założenia. Renowacja to zespół działań technicznych nakierowanych na likwidację powtarzających się uszkodzeń, przy czym aplikowane materiały nie odgrywają żadnej roli w przenoszeniu obciążeń, które nadal przenosi dotychczasowa konstrukcja. Rekonstrukcja to zespół działań technicznych polegających na wprowadzeniu do wnętrza uszkodzonego rurociągu nowej konstrukcji zdolnej do samodzielnego przenoszenia obciążeń. Wymiana jest zespołem działań technicznych sprowadzających się do zniszczenia konstrukcji uszkodzonego rurociągu i wprowadzenia w jego miejsce nowego przewodu zdolnego do samodzielnego przenoszenia obciążeń. Średnica zewnętrzna nowego rurociągu może być równa bądź większa niż starego. Stary rurociąg zostaje usunięty z gruntu albo jego rozdrobnione fragmenty pozostają w gruncie. Należy zauważyć, że różnorodność 
technik bezwykopowych umożliwia przywrócenie pełnej sprawności systemowi kanalizacyjnemu, niezależnie od rodzaju uszkodzenia, które wymagają naprawy.

Metody bezwykopowe budowy rurociągów podziemnych wykorzystywane są głównie w miastach do budowy lub rozbudowy sieci uzbrojenia miast, na przykład do budowy podziemnej sieci infrastrukturalnej, w tym rurociągów wodno-kanalizacyjnych. Jednakże technologie te należy stosować, kiedy istnieją ku temu wyraźne przesłanki ekonomiczne, społeczne, ekologiczne lub prawne. Kryteria ekonomiczne w analizie wyboru metody są kluczowe i należy je uwzględnić, aby nie doprowadzić do sytuacji, w której naprawa będzie wykonywana za pomocą technologii niezasadnej dla danego przypadku. Należy wziąć pod uwagę i inne wymagania funkcjonalne, jak łatwość wykonywania dodatkowych podłączeń, usuwania ewentualnych uszkodzeń oraz odporność na czynności eksploatacyjne. Uwarunkowania ekonomiczne występują na przykład przy budowie lub rehabilitacji technicznej przewodów kanalizacyjnych na dużych głębokościach w trudnych warunkach gruntowo-wodnych, przy jednoczesnych kolizjach z istniejącymi sieciami, które podczas prowadzenia robót metodami tradycyjnymi łatwo uszkodzić. W takich warunkach metody tradycyjne byłyby znacznie kosztowniejsze choćby ze względu na koszty wykonania wykopów, odwodnienia oraz koszty zajęcia pasa ulicy i odtwarzania konstrukcji jezdni.

Uwarunkowania społeczne mogą występować szczególnie w centrach miast, gdzie prowadzenie robót metodami tradycyjnymi powodowałoby znaczne utrudnienia w organizacji ruchu, tym bardziej że układy komunikacyjne w większości polskich miast są niesprawne nawet bez dodatkowych zakłóceń. Uwarunkowania te wiążą się także ze wzrostem świadomości ekologicznej decydentów i społeczeństwa.

Uwarunkowania ekologiczne są bardzo istotne, ponieważ prowadzenie robót $w$ tradycyjnych wykopach otwartych to ingerencja w środowisko naturalne (np. przez obniżanie poziomu wód gruntowych, konieczność wycięcia drzew czy zwiększenie ilości emitowanych spalin w wyniku poruszania się samochodów wydłużonymi w stosunku do normalnych tras objazdami).

Uwarunkowania prawne są głównie konsekwencją przynależności Polski do UE, gdzie obowiązują bardziej restrykcyjne przepisy w zakresie ochrony środowiska. Ten stan rzeczy przekłada się przykładowo na rygorystyczne wymogi dotyczące kontroli szczelności przewodów kanalizacyjnych. Istnieje zatem konieczność uszczelniania wielu sieci, a to może 
przyczynić się do jeszcze większego wzrostu zapotrzebowania na technologie bezwykopowe w przyszłości.

Wśród wielu zalet stosowania technologii bezwykopowych bardzo ważną jest brak lub minimalizacja robót ziemnych. Przy budowie nowych przewodów zachodzi potrzeba usunięcia tylko tej objętości gruntu, która jest równa kubaturze wbudowywanych bezwykopowo rur. Odnowa bezwykopowa przewodów kanalizacyjnych z kolei często w ogóle obywa się bez robót ziemnych. Można wówczas skorzystać z dostępu do przewodów poprzez studzienki kanalizacyjne. Ponadto technologie te wymagają tylko wykonania wykopów początkowych i końcowych, a niektóre, stosowane w odnowie kanalizacji, nie wymagają wykopów, a w związku z tym także rozbiórki i odtworzenia nawierzchni ulicznych. Niewątpliwą zaletą tych technologii jest także ograniczenie kosztów transportu ze względu na węższy w porównaniu z tradycyjnymi metodami wykopowymi zakres robót bądź eliminację innych robót, co dodatkowo pozwala na istotną redukcję uciążliwości środowiskowych. Warto jeszcze wspomnieć, że technologie te nie powodują zanieczyszczania wód gruntowych, nie stwarzają zagrożeń dla zieleni miejskiej ani ryzyka uszkodzenia innych sieci lub kabli.

Reasumując, liczne zalety technologii bezwykopowych w każdym wymiarze - technicznym, ekonomicznym i ekologicznym - przyczyniają się do ich dynamicznego rozwoju. Bezwykopowa rehabilitacja techniczna jest ekologiczną alternatywą dla tradycyjnych metod w wykopach otwartych, a w wielu wypadkach jest jedynym możliwym technicznie rozwiązaniem (np. przy budowie rurociągu pod przeszkodami terenowymi czy przy wymianie rur ułożonych pod ulicami o dużym natężeniu ruchu ulicznego $w$ dużych miastach lub w zabytkowym terenie miejskich starówek). Jednak wydaje się, że tradycyjne metody wykopowe nadal będą stosowane. Przede wszystkim dlatego, że techniki bezwykopowe są bardziej kosztowne od tradycyjnych metod, szczególnie w przypadku budowy przewodów płytko ułożonych poza ciągami ulicznymi, w gruntach nienawodnionych.

\subsection{Ekoinnowacje technologiczne}

Innowacje technologiczne są jednym z typów innowacji i oznaczają wprowadzenie do praktyki w przedsiębiorstwie nowych lub znacząco ulepszonych metod produkcji lub dostaw kluczowych dla działalności firmy. Może tutaj chodzić o zastosowane w przedsiębiorstwie nowe 
i ulepszone procesy technologiczne, maszyny, urządzenia i narzędzia, oprogramowanie oraz sposób tworzenia i świadczenia usług. Natomiast ekoinnowacje technologiczne, które oznaczają jakiekolwiek innowacje przynoszące korzyści dla środowiska naturalnego, oprócz wymienionych wyżej cech prowadzą do większej produktywności energii i surowców oraz gleby, zmniejszonej emisji zanieczyszczeń i odpadów, a także sprzyjają zachowaniu bioróżnorodności i krajobrazu. Jednocześnie podnoszą jakość środowiskowych technologii ponad obowiązujące normy, wyznaczając tym samym wyższe standardy w ochronie środowiska. Ekoinnowacje prowadzą więc do znacznego i widocznego postępu w realizacji celów zrównoważonego rozwoju.

Można wskazać wiele przykładów wdrożenia ekoinnowacji technologicznych w Polsce i na świecie. Wśród krajowych przykładów na uwagę zasługuje Oczyszczalnia Ścieków „Czajka” w Warszawie², która jest obecnie największą i najnowocześniejszą oczyszczalnią ścieków w Polsce. W układzie technologicznym znalazły się tam między innymi obiekty i urządzenia do prowadzenia gospodarki osadowej, w których osady ściekowe poddawane są stabilizacji i odwodnieniu. Powstający biogaz jest wykorzystany do produkcji energii cieplnej i elektrycznej. Warto zauważyć, że wszystkie obiekty oczyszczania wstępnego oraz gospodarki osadowej są całkowicie zhermetyzowane, a powietrze odciągane z obiektów technologicznych jest neutralizowane w systemie oczyszczenia powietrza. W oczyszczalni zastosowano także najnowocześniejsze technologie termicznego przekształcania odpadów i oczyszczania spalin.

Kolejnym przykładem może być Oczyszczalnia Ścieków Łódzkiej Aglomeracji Miejskiej (GOŚ-ŁAM) ${ }^{3}$, w której w ostatnich latach wdrożono wiele innowacyjnych rozwiązań przyjaznych środowisku, uzyskując jednocześnie wymierny efekt ekonomiczny. W oczyszczalni wykorzystywany jest między innymi system biologicznego oczyszczania ścieków MUCT, dzięki czemu parametry ścieków odprowadzanych do rzeki Ner spełniają wszystkie wymogi norm europejskich, szczególnie w zakresie redukcji szkodliwych związków biogennych (fosforu i azotu). Biogaz odzyskany z osadów ściekowych jest wykorzystywany do produkcji ciepła bądź przetwarzany na prąd elektryczny. Rysunek 5.3 przedstawia widok ogólny na GOŚ w Łodzi. Na pierwszym planie można zauważyć innowacyjne komory osadu czynnego, a na dalszym planie - komory fermentacyjne osadu czynnego.

2 http://www.mpwik.com.pl/fundusze-unijne/oczyszczalnia-sciekow-czajka.

3 http://www.gos.lodz.pl/. 


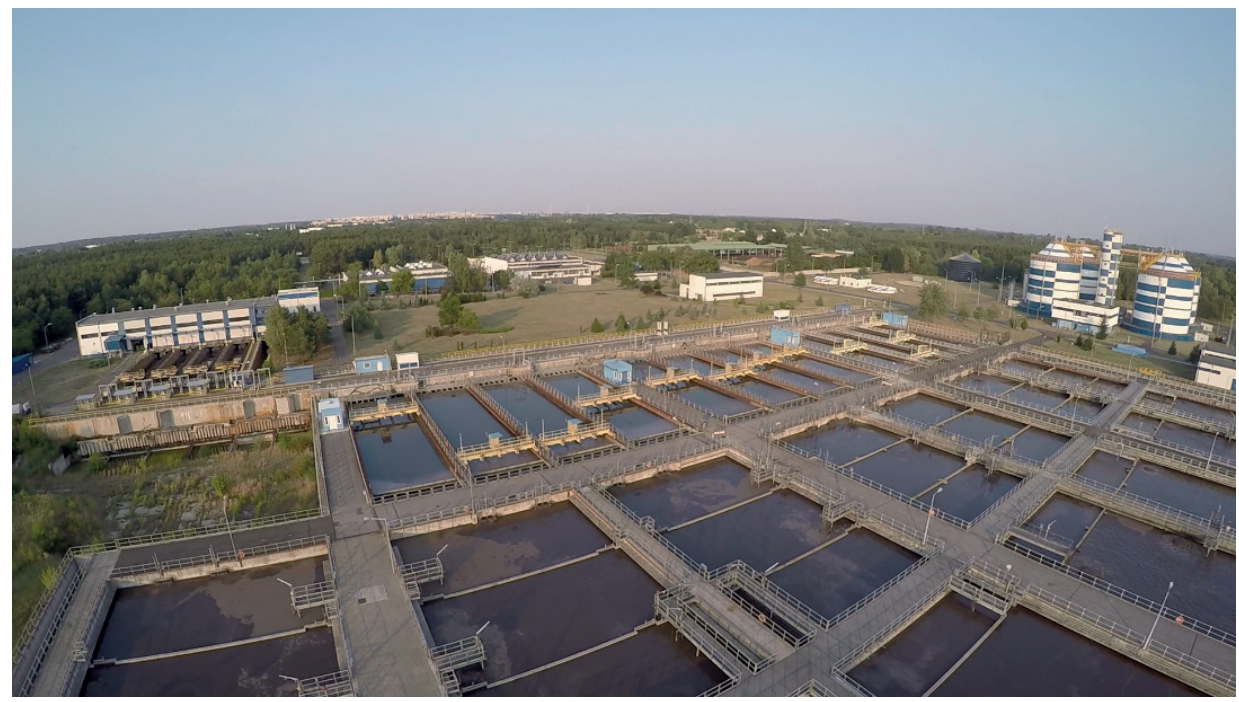

Rys. 5.4. Widok ogólny GOŚK w Łodzi

Źródło: Archiwum Grupowej Oczyszczalni Ścieków w Łodzi Sp. z o. o.

Z kolei w jednym z najbardziej znanych zakładów produkcji piwa w Polsce prawie $100 \%$ energii elektrycznej wykorzystywanej w produkcji pochodzi ze źródeł odnawialnych. Ponadto zredukowano grubość blachy potrzebnej do produkcji puszek gładkich, dzięki czemu zmniejszyły się ilość zużywanego materiału oraz wykorzystywanej energii.

Należy zwrócić uwagę na wzrost w ostatnim czasie poziomu ekoinnowacyjności branży budowlanej, ponieważ w zakresie budownictwa pojawiło się wiele interesujących, przyjaznych środowisku rozwiązań. Umiejętne zestawienie dostępnych rozwiązań technicznych daje możliwość poprawy wielu parametrów eksploatacyjnych budynku. Inwestorzy zwracają obecnie uwagę między innymi na współczynnik przepuszczalności energii słonecznej, montują kolektory słoneczne, pompy ciepła lub też stosują ekologiczne i wysokiej jakości materiały. Najważniejszym kryterium poszukiwania innowacji w zakresie budownictwa jest efektywność energetyczna. Istnieje konieczność lepszego wykorzystania jej potencjału, jak również zwiększenia stopnia wykorzystania odnawialnych źródeł energii, ponieważ w większości gospodarstw domowych ponad $70 \%$ energii zużywane jest do ogrzewania pomieszczeń. 
Ze względu na występujące susze hydrologiczne, stale pogarszający się stan wód powierzchniowych oraz wzrost wymagań stawianych wodzie przeznaczonej do spożycia przedsiębiorstwa zmuszone są do poszukiwania alternatywnych źródeł wody oraz innowacyjnych technologii ich uzdatniania. W celu pozyskania wód i ich uzdatniania konieczne jest zastosowanie zaawansowanych innowacyjnych rozwiązań z wykorzystaniem technologii przyjaznych środowisku, a do takich należą techniki membranowe, opisane w rozdziale trzecim niniejszego podręcznika. Coraz częściej proponuje się na przykład zintegrowane układy wykorzystujące mikrofiltrację lub ultrafiltrację oraz nanofiltrację do zmiękczania wody, a także bioreaktory membranowe.

Natomiast w odniesieniu do światowych ekoinnowacji technologicznych można wyróżnić między innymi:

- elektrownie wykorzystujące turbiny parowe i gazowe do wytwarzania wody pitnej z wody morskiej w procesie odsalania;

- budowę systemów uzdatniania wody gruntowej, wody lekko zasolonej oraz słonej;

- zastąpienie wchodzącego w skład betonu kruszywa biomasą;

- wykorzystanie osadów ściekowych do produkcji kompozytowych materiałów budowlanych;

- wykorzystanie modularnych paneli kompozytowych jako materiałów budowlanych;

- wypełnianie paneli ściennych pianką wytwarzaną ze szkła;

- zastosowanie nowych układów technologicznych, głównie reaktorów do procesu pirolizy lub zgazowania biomasy;

- budowę instalacji do oczyszczania wody - tatwych do transportu i bez użycia chemikaliów, szczególnie w rejonach dotkniętych katastrofami naturalnymi.

Interesującym przykładem innowacji jest także kompaktowa suszarnia mikrofalowa, przeznaczona do osuszania osadów ściekowych i innych materiałów o wysokim stopniu uwodnienia. W urządzeniu tym wykorzystuje się energię mikrofal do osuszania w sposób ciągły. Zastosowanie takiej suszarni przynosi wiele korzyści ekologicznych i ekonomicznych, a przede wszystkim pozwala na zagospodarowanie zalegających 
osadów, redukcję szkodliwych oparów, zmniejszenie objętości osadów oraz uzyskanie produktu będącego źródłem energii odnawialnej, a jednocześnie niestanowiącego zagrożenia dla środowiska.

Wiele państw Unii Europejskiej w ostatnich latach doceniło znaczenie innowacji ekologicznych w rozwoju swojego kraju. Podkreśla się, że zarówno ekoinnowacje, jak i technologie środowiskowe sprzyjają wzrostowi gospodarczemu i powstawaniu nowych miejsc pracy. W Polsce ekoinnowacje technologiczne wdrażane są jednak wciąż w zbyt małym zakresie i w celu poprawy tej sytuacji konieczne wydaje się silniejsze wsparcie dla przedsiębiorstw na przykład przez instytucje do tego powołane, takie jak ośrodki transferu technologii, inkubatory technologiczne oraz parki naukowo-technologiczne. Szczególną rolę powinny tutaj odgrywać inkubatory przedsiębiorczości, które specjalizują się we wspieraniu nowych firm z branży zaawansowanych technologii. Istotne jest również stworzenie nowych i bardziej skutecznych zachęt do wprowadzania i stosowania technologicznych innowacji ekologicznych na szerszą skalę.

\section{Literatura}

Grądzki R. (red.), Rozwój zrównoważony - innowacje w technice, Wydawnictwo MediaPress, Łódź 2008.

Gromiec M., Słowik N. (red.), Zastosowanie nowych technologii w sektorze ochrony środowiska, Wydawnictwo NFOŚiGW, Warszawa 2006.

Janosz-Ratajczyk M. (red.), Wybrane procesy jednostkowe w inżynierii środowiska, Wydawnictwo Politechniki Częstochowskiej, Częstochowa 2004.

Komunikat Komisji Wspólnot Europejskich, Stymulowanie technologii w kierunku zrównoważonego rozwoju: Plan działań UE w zakresie Technologii Śro-

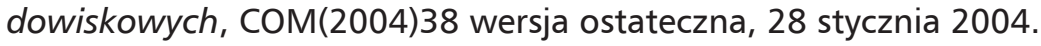

Komunikat Komisji Wspólnot Europejskich, Sprawozdanie z realizacji Planu dziatań na rzecz technologii dla środowiska (2005-2006), COM(2007)162 wersja ostateczna.

Kujawski W., Bezwykopowa renowacja kanalizacji ściekowej jako element utrzymania zbiorczego systemu kanalizacyjnego PEWIK Gdynia, [w:] Kompleksowa Gospodarka wodno-ściekowa w aspekcie norm unijnych, Materiały seminaryjne Nr 50(2006), Wydawnictwo Instytutu Technologiczno-Przyrodniczego, Falenty 2006.

Kuliczkowski A., Technologie bezwykopowe w inżynierii środowiska, Wydawnictwo Seidel-Przywecki, Warszawa 2010.

Piechurski F.G., Współczesne techniki naprawy sieci wodociągowej, „Wodociągi i Kanalizacja", nr 7-8(137-138)/2015, s. 42-47. 
Pisarczyk St., Elementy budownictwa ochrony środowiska, Oficyna Wydawnicza Politechniki Warszawskiej, Warszawa 2008.

Prawo ochrony środowiska (Dz.U. z 2006 r. Nr 129, poz. 902).

Szpor A., Śniegocki A., Ekoinnowacje w Polsce. Stan obecny, bariery rozwoju, możliwości wsparcia, Instytut Badań Strukturalnych, Warszawa 2012.

Woźniak E., Strojny. J., Wojnicka L. (red.), Ekoinnowacyjność dziś i jutro - wyzwania, bariery rozwoju oraz instrumenty wsparcia, Wydawnictwo PARP, Warszawa 2010.

Urbaniak A., Zakrzewski P., Inteligentne systemy w inżynierii i ochronie środowiska, Wydawnictwo PZITS, Oddział Wielkopolski, Poznań 2007.

Zarzycki R., Imbierowicz M., Stelmachowski M., Wprowadzenie do inżynierii i ochrony środowiska, t. 1: Ochrona środowiska naturalnego, Wydawnictwa Naukowo-Techniczne, Warszawa 2007.

Zielony wzrost, zielony zysk. Jak zielona gospodarka stymuluje gospodarkę, Roland Berger Strategy Consultants, Oficyna Wolters Kluwer., Warszawa 2011.

Zwierzchowska A., Technologie bezwykopowej budowy sieci gazowych, wodociągowych i kanalizacyjnych, Wydawnictwo Politechniki Świętokrzyskiej, Kielce 2009.

Zwierzchowska A., Optymalizacja doboru metod bezwykopowej budowy rurociągów podziemnych, Wydawnictwo Politechniki Świętokrzyskiej, Kielce 2003.

http://www.actclean.gig.eu/pl/remas/czystsza-produkcja.html.

http://www.gos.lodz.pl/.

http://www.mpwik.com.pl/fundusze-unijne/oczyszczalnia-sciekow-czajka. 


\section{Rozdział 6}

\section{Obiekty budowlane służące ochronie środowiska}

\subsection{Wprowadzenie}

Podstawy inżynierii środowiska jako dyscypliny naukowej były tworzone przede wszystkim na wydziałach budownictwa. Studenci kierunków technicznych obejmujących budownictwo tak jak przed laty, tak i teraz zdobywają wiedzę i umiejętności między innymi w zakresie procesów i technologii budowlanych przyjaznych środowisku naturalnemu.

Sektor budownictwa jest kluczową branżą całej gospodarki w Unii Europejskiej. Ze względu na wielkość tego sektora, a także liczne powiązania z innymi gałęziami gospodarki ma on ogromny wpływ na środowisko. Zużywa ogromną ilość surowców stanowiących źródło materiałów budowlanych, jak również bardzo duże ilości energii i wody, jednocześnie emitując do środowiska znaczne ilości zanieczyszczeń.

Budownictwo jest to technika wznoszenia i konserwacji obiektów budowlanych oraz związana z nią dziedzina wiedzy. Obiektami budowlanymi są: budynek wraz z instalacjami i urządzeniami technicznymi, budowla stanowiąca całość techniczno-użytkową wraz z instalacjami i urządzeniami oraz obiekt małej architektury. Budynkiem jest obiekt budowlany, który jest trwale związany z gruntem, wydzielony z przestrzeni za pomocą przegród budowlanych, mający fundamenty i dach. Budowla bądź obiekt małej architektury to obiekt budowlany niemający jednej z wymienionych wyżej cech. Obiektami małej architektury są niewielkie obiekty. Budowlą natomiast jest każdy obiekt budowlany niebędący budynkiem lub obiektem małej architektury'.

Obiekty budowlane należy projektować, budować i utrzymywać zgodnie z przepisami, w tym techniczno-budowlanymi oraz zasadami wiedzy technicznej i inżynieryjnej. Powinny one także zapewniać bezpieczeństwo oraz chronić środowisko przed zanieczyszczeniem. Obecna oferta rynkowa materiałów budowlanych daje architektom wiele możliwości w zakresie zastosowania rozwiązań zarówno funkcjonalnych

Na podstawie Prawo budowlane (Dz.U. z 2013 r., poz. 1409). 
i technicznych, jak i innowacyjnych, aby na szerszą skalę wdrażać w Polsce założenia budownictwa zrównoważonego. Polega ono głównie na wykorzystaniu przyjaznych środowisku materiałów, minimalizowaniu zużycia energii oraz zanieczyszczeń, a także zrównoważonym zazielenianiu terenu wokół budynku. Koncepcja zrównoważonego rozwoju w budownictwie zyskuje coraz szersze poparcie w naszym kraju, dzięki czemu wzrasta liczba budynków energooszczędnych i pasywnych.

\subsection{Obiekty budowlane mające znaczenie dla ochrony środowiska}

Obiekty budowlane mające znaczenie dla ochrony środowiska to zgodnie z prawem budowlanym przeważnie budowle, którym towarzyszą też budynki. Obiekty te stanowią najczęściej: budynki, hale, zbiorniki nadziemne i podziemne, wieże, rurociągi, pomosty, szyby, studnie, zbiorniki ziemne itp. W związku z ich rozmaitym przeznaczeniem wyróżniają się przede wszystkim wymaganiami technologicznymi, eksploatacyjnymi oraz wielkością. Najczęściej wymaga się, by obiekty te były bezpieczne i trwałe, tzn. aby funkcjonowały 70-100 lat i więcej. Zapewnienie trwałości obiektów budowlanych tego typu polega na zabezpieczeniu przed wpływami zewnętrznymi lub dobraniu do ich wykonania odpowiednich materiałów odpornych na spodziewaną agresywność.

Wykonane są najczęściej z następujących materiałów: betonu, żelbetu, stali, metali nieżelaznych, wyrobów ceramicznych, szkła, drewna, tworzyw sztucznych, gruntów, skał, odpadów itp. Materiały te mają różne właściwości fizyczne i wytrzymałościowe, także odporność korozyjną i różnie zachowują się w czasie eksploatacji w środowisku, przeważnie agresywnym. Obiekty betonowe mające znaczenie dla ochrony środowiska są realizowane w postaci monolitycznej (np. betonowe i żelbetonowe) lub mogą być montowane z elementów prefabrykowanych. Z gruntów budowane są na przykład zapory ziemne i obwałowania rzek, obwałowania zbiorników wodnych i składowisk odpadów. Natomiast do uszczelniania zbiorników wodnych i składowisk odpadów używa się różnych materiałów chemicznych i tworzyw sztucznych oraz gruntów. Elementy konstrukcyjne budynków i hal oraz zbiorniki i rurociągi, a także inne urządzenia techniczne wykonywane są ze stali i metali nieżelaznych. Konstrukcje stalowe wymagają odpowiednich zabezpieczeń antykorozyjnych.

Obiekty związane z gospodarką wodną i zabezpieczeniem przed powodziami to przede wszystkim: jazy i zapory, zbiorniki retencyjne 
(zbiorniki wodne) oraz wały i groble przeciwpowodziowe. Jazy i zapory (tamy) są obiektami hydrotechnicznymi i służą do piętrzenia i retencji wody w dolinach rzecznych. Zbiorniki wodne utworzone przez spiętrzenie zaporami, nazwane też jeziorami zaporowymi, służą w większości przypadków ochronie przed powodziami. $Z$ reguły nie są one napełniane do maksymalnej rzędnej piętrzenia, lecz pozostawia się w nich wolną pojemność, w której można gromadzić nadmiar wody z okresu wezbrań i tym sposobem zabezpiecza się dolinę przed powodzią poniżej zapory. Przy zbiornikach wodnych buduje się też korzystne dla środowiska elektrownie wodne, wykorzystujące potencjał rzek.

Obwałowania rzek i groble są podstawową formą ochrony przeciwpowodziowej dolin rzecznych. Budowa i utrzymanie wałów przeciwpowodziowych to bardzo ważne problemy budowlane i z zakresu ochrony środowiska. Dobry stan obwałowań skutecznie zabezpiecza doliny przed powodziami.

Obiekty budowlane związane z gospodarką wodno-ściekową to najczęściej:

- obiekty technologiczne, w których procesy przebiegają pod stałym nadzorem personelu, jak na przykład pompownie, stacje filtrów, pomieszczenia krat i rozdrabniarek, tunele przewodowe itp.;

- obiekty technologiczne służące do transportu lub przechowywania cieczy, dostępne dla ludzi okresowo (podczas budowy, przeglądu lub remontu), a należą do nich na przykład kanały, rurociągi, zbiorniki, osadniki, komory fermentacyjne itp.;

- obiekty specjalne, jak na przykład łaźnie, pralnie, laboratoria, budynki administracyjno-biurowe itp.

Natomiast do obiektów budowlanych związanych ze składowaniem i zagospodarowaniem odpadów można zaliczyć:

- mokre składowiska odpadów przemysłowych;

- składowiska suche odpadów przemysłowych i komunalnych;

- składowiska specjalne i podziemne odpadów niebezpiecznych;

- zakłady przemysłowego przetwarzania i wykorzystania odpadów i osadów ściekowych. 
Projektowanie, wykonawstwo i eksploatacja obiektów budowlanych, w tym przeważnie budowli służących ochronie środowiska, wymagają współpracy specjalistów z różnych dziedzin: inżynierii sanitarnej, wodnej, budownictwa lądowego (przemysłowego), inżynierii ochrony środowiska, jak również ekonomistów.

\subsection{Budownictwo ekologiczne}

Omawiając zagadnienia dotyczące budownictwa służącego ochronie środowiska przyrodniczego, należy również zwrócić uwagę na budownictwo ekologiczne, którego głównym celem jest ograniczenie negatywnego wpływu budynków na środowisko naturalne oraz zdrowie człowieka. Na wszystkich etapach procesu inwestycyjnego stosowane są w nim bowiem technologie środowiskowe lub innowacyjne rozwiązania, które łączą korzystne efekty ekonomiczne z dbałością o zdrowie i komfort użytkowników, a także o ochronę środowiska naturalnego. Cele szczegółowe to między innymi efektywne wykorzystanie energii i wody, ograniczenie ilości odpadów i emitowanych zanieczyszczeń.

W literaturze przedmiotu brak obecnie jednej, oficjalnie uznanej i potwierdzonej naukowo definicji budynku ekologicznego, ponieważ istnieją różnice $\mathrm{w}$ ocenie rangi produktywności różnych zasobów: wody, energii czy materiałów zawierających surowce wtórne, ale też wpływu budynku na zdrowie człowieka. Często stosuje się wymiennie terminy: „budownictwo ekologiczne”, „energooszczędne”, ,zrównoważone” albo „zielone”, jednak nie są one całkowicie równoznaczne. Budownictwo ekologiczne jest bowiem pojęciem szerszym w stosunku do budownictwa energooszczędnego.

Ogólnie budynek ekologiczny można zdefiniować jako budynek cechujący się zmniejszeniem poboru energii i produkcji zanieczyszczeń, przy którego budowie wykorzystano materiały przyjazne środowisku naturalnemu. Działalność w zakresie budownictwa ekologicznego powinna zatem zapewniać:

- zmniejszenie zużycia zasobów naturalnych, zarówno do wytworzenia materiałów, jak i w procesie budowy;

- obniżenie emitowanych zanieczyszczeń;

- zmniejszenie ilości odpadów produkcyjnych lub ich ponowne wykorzystanie;

- wykorzystanie odnawialnych zasobów energii. 
Biorąc pod uwagę wymienione zasady, należy zadbać o to, aby w całym procesie realizacji projektu budowlanego w sposób zrównoważony wykorzystać surowce do produkcji materiałów budowlanych, energię, wodę oraz tereny przeznaczone pod budowę. Istotne są lokalizacja w terenie i oddziaływanie mas powietrza na budynek, głównie osłonięcie od wiatru. Pod względem rozwiązań architektonicznych należy zwrócić uwagę na zwartość bryły budynku, układ pomieszczeń oraz zminimalizowanie liczby otworów okiennych od strony północnej. Warto zadbać także o wysoką izolacyjność termiczną przegród zewnętrznych i wewnętrznych, szczególnie wydzielających pomieszczenia o różnych temperaturach, a także o sposoby wymiany powietrza, na przykład przez odzysk ciepła z powietrza usuwanego z pomieszczeń. W budynkach energooszczędnych bardzo często stosuje się źródła ciepła wykorzystujące odnawialne zasoby energii, w tym głównie promieniowanie słoneczne (budynki helioaktywne), a także montowana jest wysokosprawna i opomiarowana instalacja grzewcza, wyposażona w automatykę pogodową.

Technologie związane $z$ budownictwem energooszczednym są bardzo pożądane społecznie i ekonomicznie. Obecnie powstające budynki muszą bowiem spełniać wymagania ochrony cieplnej budynku, a w szczególności oszczędności energii i izolacyjności cieplnej. Aktualnie obowiązujące dyrektywy unijne ${ }^{2} w$ tym obszarze wyznaczają cel budowania obiektów prawie zeroenergetycznych po 2020 roku oraz wprowadzają obowiązek budowania obiektów o minimalnym zapotrzebowaniu na energię. Do realizacji tych celów konieczne są jednak odpowiednie instrumenty prawne i rynkowe. Wprawdzie zdaniem niektórych ekonomistów zastosowanie technologii środowiskowych w procesie realizacji projektu budowlanego może wiązać się z poniesieniem większych kosztów w porównaniu z budynkiem tradycyjnym, jednak w procesie użytkowania budynku ekologicznego można odnieść wymierne korzyści w postaci sporych oszczędności.

Zastosowane w budynkach ekologicznych technologie pozwalają w znacznym stopniu zredukować zużycie energii. W przypadku domów pasywnych oszczędność ta może sięgać nawet kilkuset procent w stosunku do domów tradycyjnych. Istotnym elementem tych budynków jest wykorzystanie odnawialnych źródeł energii, na przykład poprzez gruntowy wymiennik ciepła, kolektory słoneczne, kotły na biomasę czy też pompy ciepła. Standard pasywny skupia się na dwóch następujących

2 Dyrektywa Parlamentu Europejskiego i Rady 2010/31/UE z dnia 19 maja 2010 r. w sprawie charakterystyki energetycznej budynków (Dz.Urz. UE L 153 z 18.06.2010, s. 13). 
strategiach: redukcji do minimum strat energii cieplnej przez przenikanie i niekontrolowaną wentylację oraz pozyskiwanie jak największej ilości zysków ciepła ze słońca zimą. Standardy te wdrażane są przy zachowaniu maksymalnego komfortu klimatycznego wewnątrz pomieszczeń oraz wysokiej trwałości budynku.

Obecny rozwój technologii pozwala na jeszcze bardziej wydajne użytkowanie energii w budynkach. Budynki zeroenergetyczne nie zużywają energii od dostawców zewnętrznych, a jedynie energię odnawialną w postaci biomasy lub biopaliw. System ten jest w stanie pokryć do $80 \%$ zapotrzebowania na energię. W kotłowniach tych budynków wykorzystuje się dwa podstawowe źródła energii: promieniowanie słoneczne, które jest zamieniane w ciepło użytkowe za pomocą wysokoefektywnych absorberów oraz energię zawartą w powietrzu, która dzięki odpowiedniemu systemowi sprężania osiąga temperaturę do kilkudziesięciu stopni. Ważne i korzystne z wielu względów jest zastosowanie kolektorów hybrydowych, które pozwalają uzyskać z nich zarówno energię cieplną, jak i elektryczną, co nie jest możliwe przy zwykłych kolektorach. Natomiast budynki plusoenergetyczne to budynki o dodatnim bilansie energii, gdyż produkują więcej energii, niż same zużywają.

Jednym z kluczowych sposobów oszczędności energii potrzebnej do ogrzewania domu oraz zmniejszenia ilości zanieczyszczeń powstałych w tym procesie jest wykorzystanie pomp ciepła. Odpowiednia instalacja pompy ciepła (np. układ rurek wypełnionych glikolem z wodą) pobiera ciepło z gleby, powietrza czy wody gruntowej, następnie kondensuje to ciepło za pomocą sprężarki i oddaje otoczeniu. Najbardziej powszechne są pompy geotermalne, które „pozyskują” ciepło z wnętrza ziemi.

Aby zmniejszyć zużycie energii na ogrzewanie, należy również rozważyć umiejscowienie źródeł ciepła. W większości przypadków ogrzewanie podłogowe wydaje się korzystniejsze niż tradycyjne umieszczenie grzejników pod oknem, gdyż z wykorzystaniem tej samej ilości energii jesteśmy w stanie dostarczyć ciepło dla większej powierzchni.

Podsumowując zagadnienia dotyczące ekobudownictwa, można wymienić następujące jego kluczowe elementy: zrównoważony projekt, oszczędne zużycie wody, ekomateriały budowlane, zrównoważona architektura wnętrz, minimalizacja zużycia energii, ograniczenie odpadów i toksyn, a także tanie utrzymanie budynku. Uwzględnienie tych elementów na każdym etapie procesu inwestycyjno-budowlanego pozwoli na uzyskanie wymiernych korzyści ekonomiczno-społeczno-środowiskowych, zgodnie z koncepcją zrównoważonego rozwoju. 


\section{Literatura}

Anisimow S. (red.), Nowoczesne rozwiązania w inżynierii i ochronie środowiska, Politechnika Wrocławska, Wrocław 2011.

Dyrektywa Parlamentu Europejskiego i Rady 2010/31/UE z dnia 19 maja 2010 r. w sprawie charakterystyki energetycznej budynków (Dz.Urz. UE L 153 z 18.06.2010, s. 13).

Gromiec M., Słowik N. (red.), Zastosowanie nowych technologii w sektorze ochrony środowiska, Wydawnictwo NFOśiGW, Warszawa 2006.

Kręc K., Wybrane zagadnienia z inżynierii środowiska: ogrzewnictwo $i$ wentylacja, zaopatrzenie w wodę $i$ budownictwo wodne, Oficyna Wydawnicza Politechniki Warszawskiej, Warszawa 2002.

Królczyk B., Terminologia budownictwa - wspólny cel: oszczędzanie energii, „Czysta Energia”, nr 9(169)/2015, s. 24-26.

Lipińska D., Ekoinnowacje szansą wzrostu konkurencyjności gospodarki w kontekście unijnej polityki rozwojowej do 2020 roku, [w:] A. Grynia (red.), Wpływ globalizacji i integracji na konkurencyjność nowych krajów członkowskich Unii Europejskiej, Wydział Ekonomiczno-Informatyczny UB, Wilno 2013, s. 106-120.

Lipińska D., Wsparcie ekoinnowacji na poziomie UE - wybrane instrumenty instytucjonalne i finansowe, [w:] L. Woźniak (red.), Ekoinnowacje w Polsce, Izba Gospodarcza „Grono Targowe Kielce”, Kielce 2013, s. 15-23.

Mikoś J., Budownictwo ekologiczne, Wydawnictwo Politechniki Śląskiej, Gliwice 2000.

Pisarczyk St., Elementy budownictwa ochrony środowiska, Oficyna Wydawnicza Politechniki Warszawskiej, Warszawa 2008.

Polak K., Ekologiczne budynki, „Ekologia i Rynek”, nr 9(30)/2014, s. 9-12.

Prawo budowlane (Dz.U. z 2013 r., poz. 1409).

Szkarowski A., Iwanow A., Analiza inwestycyjna $w$ budownictwie $i$ inżynierii środowiska, Wydawnictwo Uczelniane Politechniki Koszalińskiej, Koszalin 2011.

Zielone budowanie, „Przegląd Komunalny”, nr 10/2014, dodatek specjalny, s. 8-9. http://www.ekoportal.eu/Artykuly/Budownictwo_pasywne.html.

http://www.ecosquad.pl/ekologiczna-izolaja-termiczna-domu-.html.

http://muratordom.pl/dzial-dedykowany/sunex/ograniczenie-kosztowogrzewania-domu-co-jest-kotlownia-solarna,846_12571.html. 


\section{Rozdział 7}

\section{Inżynieria środowiska w służbie ochrony powietrza Procesy oczyszczania gazów odlotowych}

\section{1. Źródła i rodzaje zanieczyszczeń powietrza}

Zanieczyszczeniami powietrza nazywamy wszelkie substancje (gazy, ciecze, ciała stałe), które znajdują się w powietrzu atmosferycznym, ale nie są jego naturalnymi składnikami. Jednakże zanieczyszczenia stanowią także substancje będące jego naturalnymi składnikami, lecz występujące w ilościach znacznie przewyższających normy i standardy środowiskowe. Naturalnymi składnikami powietrza są następujące gazy: azot (78\%), tlen (21\%) i mieszanina pozostałych gazów, takich jak dwutlenek węgla, para wodna i gazy szlachetne (1\%).

Źródło emisji zanieczyszczeń powietrza to miejsce, w którym następuje wprowadzenie do powietrza substancji zanieczyszczających. Wyróżniamy w tym wypadku źródła naturalne i antropogeniczne. Do naturalnych zalicza się na przykład: pożary lasów, burze pyłowe, pyły kosmiczne, wybuchy wulkanów, wyładowania atmosferyczne, procesy gnicia obumarłych roślin i zwierząt czy wietrzenie chemiczne skał. Źródłami antropogenicznymi zanieczyszczeń powietrza są przede wszystkim zakłady energetyczne (elektrownie i elektrociepłownie), zakłady przemysłowe (głównie górnictwo, przemysł wydobywczy i chemiczny, produkcja materiałów budowlanych), kotłownie komunalne, paleniska indywidualne, środki transportu, źródła wtórne powstałe w wyniku wydalania oraz utylizacji ścieków i odpadów (np. hałdy lub wysypiska), rolnictwo (np. rozsiewanie nawozów sztucznych lub stosowanie środków ochrony roślin), a także przemiany i reakcje chemiczne zachodzące w zanieczyszczonej atmosferze.

Ze względu na znaczną różnorodność zanieczyszczeń powietrza najczęściej prowadzi się pomiar tylko tych zanieczyszczeń, które są powszechne i stanowią zagrożenie dla zdrowia ludzi i stanu atmosfery. Tego typu zanieczyszczenia nazywamy charakterystycznymi i na ogół zalicza się do nich: pyły, tlenki węgla, siarki i azotu oraz ozon. 
W zależności od stanu skupienia zanieczyszczenia powietrza można podzielić na pyłowe i gazowe. Zanieczyszczenia pyłowe to takie które składają się z mieszaniny cząstek (stałych i ciekłych, organicznych i nieorganicznych) zawieszonych w powietrzu. Zaliczamy do nich pyły ze spalania paliw oraz pyły z procesów technologicznych. Zanieczyszczenia pyłowe klasyfikuje się ze względu na wymiar ziaren (pyły o rozdrobnieniu koloidalnym oraz pyły o rozdrobnieniu makroskopowym) oraz ze względu na pochodzenie pyłu lub formy jego występowania, a mianowicie na: pyły dyspersyjne, które powstają na skutek mechanicznego rozdrabniania ciał stałych oraz pyły kondensacyjne, które są wynikiem skraplania się i zestalania par różnych substancji chemicznych (np. sadza).

Powstanie zanieczyszczeń pyłowych to wynik procesów produkcyjnych i procesów spalania. Największe ilości pyłów powstają wskutek spalania paliw stałych. Ich ilość i charakterystyka zależą od rodzaju paliwa oraz warunków spalania. Głównym źródłem zanieczyszczeń pyłowych (głównie popiołów lotnych), ale także zanieczyszczeń gazowych jest przemysł paliwowo-energetyczny. Szczególnie niebezpiecznymi zanieczyszczeniami pyłowymi są następujące pierwiastki chemiczne: chrom, rtęć, ołów, kadm, arsen, cynk oraz mangan.

Zanieczyszczenie powietrza jest problemem w skali globalnej i stanowi istotne zagrożenie dla zdrowia ludzi oraz innych elementów środowiska, szczególnie w rejonach przemysłowych i zurbanizowanych. Emitowane w jednym kraju przyczyniają się do pogorszenia jakości powietrza w innych krajach. Aby ochronić powietrze przed emisją zanieczyszczeń oraz zapobiec rozprzestrzenianiu się tych, które już dostały się do atmosfery, należy stosować najlepsze dostępne technologie środowiskowe, proponowane między innymi w ramach inżynierii środowiska.

\subsection{Działania o charakterze inżynieryjnym w ochronie powietrza}

Ochrona powietrza to obecnie jeden z najważniejszych kierunków działań w obszarze ochrony środowiska. Najogólniej polega ona na zapewnieniu jak najlepszej jakości powietrza, głównie przez:

- utrzymanie poziomów substancji w powietrzu poniżej dopuszczalnych dla nich poziomów lub co najmniej na tych poziomach oraz

- zmniejszanie poziomów substancji w powietrzu co najmniej do dopuszczalnych, gdy nie są one dotrzymane.

1 Ustawa Prawo ochrony środowiska (Dz.U. z 2001 r. Nr 62, poz. 627 ze zmianami). 
Działania inżynieryjne w dziedzinie ochrony powietrza dotyczą więc zarówno efektywnej redukcji rozmiarów już zaistniałej emisji zanieczyszczeń, jak i racjonalnej modyfikacji przynajmniej tych technologii produkcji, które wytwarzają zanieczyszczenia szczególnie uciążliwe.

Jakkolwiek zmniejszenie emisji zanieczyszczeń do powietrza jest możliwe głównie dzięki nowoczesnym, czystszym i mniej energochłonnym technologiom przemysłowym, to należy także podejmować inne działania. Z pewnością kluczowa w tym względzie będzie szeroko pojęta oszczędność energii, ale także na przykład modernizacja lub rozbudowa miejskiej sieci cieplnej, zastąpienie kotłów spalających paliwo stałe kotłami gazowymi, zamiana pieców węglowych na ogrzewanie elektryczne, dobór odpowiedniej jakości paliw w samochodach, modernizacja kotłowni z rusztem mechanicznym opalanych miałem węglowym, ograniczenie emisji z pieców węglowych w gospodarstwach domowych. Z drugiej strony należy pamiętać także o odpowiednim filtrowaniu spalin powstających w wyniku działalności przemysłu i z transportu, o wdrażaniu energooszczędnych technologii w procesach produkcyjnych, a także o wykorzystaniu na szerszą skalę OzE. Nie mniej ważne jest również sprawowanie nadzoru zapobiegawczego polegającego na podejmowaniu decyzji dotyczących lokalizacji obiektów przemysłowych będących źródłami emisji, z uwzględnieniem na przykład strefy izolacji przestrzennej pomiędzy źródłem emisji a miejscem podlegającym szczególnej ochronie.

Instalowanie wydajnych filtrów kominowych jest szczególnie istotne dla ochrony powietrza, gdyż efektywnie filtrują one zanieczyszczenia unoszące się razem z dymem. Wyróżniamy filtry: warstwowe, włókniste, membranowe oraz ziarniste.

Zmniejszenie emisji przemysłowych można osiągnąć długofalowo, poprzez doskonalenie technik procesów produkcyjnych, albo krótkofalowo - poprzez doraźne regulowanie intensywności tych procesów. Wiele przedsiębiorstw podejmuje obecnie ze względów ekonomicznych decyzję o modyfikacji istniejących przestarzałych technologii, dzięki czemu uzyskują często także większą hermetyzację produkcji. Z punktu widzenia ochrony powietrza takie działania są również oczekiwane i bardzo efektywne. Może to być na przykład odsiarczanie węgla przed jego spaleniem czy też dbałość o odizolowanie produkcji od środowiska. W przypadku ogrzewania domów korzystna jest zmiana paliwa na mniej emisyjne (np. gaz ziemny zamiast węgla) lub udoskonalenie techniczne urządzenia grzewczego, a także poprzez konstrukcję budynków (np. docieplenie). 
Ze względu na emisję przez transport ogromnej ilości zanieczyszczeń do atmosfery konieczne jest inwestowanie w ekologiczne środki transportu i modyfikacja już istniejących. W związku z tym inżynieria środowiska proponuje coraz nowsze, mniej emisyjne lub niskoemisyjne samochody wyposażone w doskonalsze silniki i lepsze katalizatory, wdrażanie nowych technologii w transporcie lotniczym, modyfikowane paliwa ( $n p$. bezołowiowe), rozbudowę transportu elektrycznego ( $\mathrm{np}$. szynobusy, trolejbusy) czy też inżynieryjne działania w dziedzinie organizacji ruchu.

Propozycje przygotowywane w ramach inżynierii ekologicznej także przyczyniają się do ochrony powietrza. Może to być na przykład tworzenie izolacyjnych pasów zieleni wokół zakładów przemysłowych, ponieważ zieleń skutecznie zatrzymuje zanieczyszczenia gazowe, a szczególnie pyły, choć oczywiście tylko w ograniczonym stopniu.

Kończąc powyższe rozważania na temat ochrony powietrza w kontekście rozwiązań proponowanych przez inżynierię środowiska, warto wspomnieć również o monitoringu zanieczyszczeń powietrza. Wykorzystuje się do tego trzy metody: pasywną, aspiracyjną i izolacyjną. Metoda pasywna polega na miesięcznej ekspozycji specjalnie przygotowanych próbników zawieszonych na wysokości około $3 \mathrm{~m}$. W metodzie aspiracyjnej zasadą jest przepuszczanie znanej objętości badanego powietrza przez odpowiednio dobrane ciekłe lub stałe substancje pochłaniające zwane sorbentami. Stosowana jest w przypadku niskiego stężenia zanieczyszczeń w miejscach poboru. Natomiast trzecia metoda - izolacyjna - polega na pobraniu do naczynia określonej objętości powietrza, którą następnie poddaje się analizie. Metoda ta jest stosowana, gdy stężenia zanieczyszczeń są wysokie.

\subsection{Główne metody oczyszczania gazów odlotowych}

Oczyszczanie gazów opiera się na procesach chemicznych i fizykochemicznych. Praktyczna, przemysłowa realizacja metod oczyszczania gazów odbywa się w procesach ciągłych, w których doprowadzanie zanieczyszczonych gazów i reagentów, a następnie odbiór produktów oczyszczania następują bez zatrzymywania aparatów i urządzeń pomocniczych. Wybór metody i technologii oczyszczania zależy od rodzaju zanieczyszczeń i ich właściwości, wielkości strumienia gazu, wymaganej sprawności oczyszczania i warunków lokalnych. Najczęściej stosowane 
metody usuwania zanieczyszczeń gazowych ze strumieni gazów odlotowych są następujące:

- absorpcja - proces polegający na dyfuzji cząstek gazu do całej objętości cieczy na skutek różnicy stężeń składników;

- adsorpcja - proces pochłaniania gazów i par na zewnętrznej powierzchni ciała stałego oraz w jego porach pod wpływem działania sił powierzchniowych;

- spalanie - metoda unieszkodliwiania gazów pochodzących z procesów technologicznych i wentylacji pomieszczeń;

- kondensacja - metoda polegająca na usuwaniu gazów odlotowych o wysokich temperaturach wrzenia poprzez chłodzenie wodą lub powietrzem;

- kompresja, czyli proces, w którym mieszanina par substancji zanieczyszczającej powietrze jest sprężana, przy równoczesnym odprowadzeniu wydzielającego się ciepła.

Warto w tym miejscu przybliżyć metodę spalania zanieczyszczeń w gazach odlotowych, służącą głównie do oczyszczania gazów zawierających domieszki palne. Warunki konieczne jej stosowania to wysoka temperatura gazów i ich zapylenie, ponadto powinny one stanowić mieszaninę różnych substancji o niewielkim stężeniu (do 0,3\% obj.). Spalanie prowadzi się w palnikach, pochodniach i komorach spalania w temperaturach $800-1200^{\circ} \mathrm{C}$. Proces ten odznacza się wysoką skutecznością (do 99\%) i w większości przypadków jest metodą bezodpadową. Jest jednak energochłonny i kosztowny, wymaga bowiem podgrzewania oczyszczonych gazów przez użycie dodatkowego paliwa gazowego lub płynnego. Wyróżniamy spalanie płomieniowe (przy wysokiej temperaturze), bezpłomieniowe (spalanie o charakterze objętościowym) lub katalityczne (w temperaturze ok. $400^{\circ} \mathrm{C}$ ). Najprostszy dopalacz katalityczny zbudowany jest z przewodu odprowadzającego gazy odlotowe, w którym umieszczono złoże katalityczne.

Interesującym rozwiązaniem inżynieryjnym w ochronie powietrza jest kombinowana metoda adsorpcji i spalania. Strumień zanieczyszczonych gazów kieruje się do urządzenia, w którym najpierw zanieczyszczenia są wychwytywane, a następnie oczyszczone gazy uchodzą na zewnątrz. Po zakończeniu tego procesu zaczyna się drugi proces 
polegający na przetransportowaniu zanieczyszczeń małym strumieniem gazu do dopalacza termicznego, w którym zanieczyszczenia są likwidowane.

Skutecznym rodzajem działań inżynieryjnych podejmowanych w zakresie ochrony powietrza jest poprawa jakości węgla używanego w procesach energetycznych. Stosowane są dwie podstawowe metody: odsiarczanie i odpirytowanie węgla. Odsiarczanie jest jednym z tańszych sposobów ograniczania emisji siarki do atmosfery. Ponadto przyczynia się do zmniejszenia ilości powstających w miejscu spalania węgla odpadów i zmniejszenia kosztów transportu. W procesie tym usuwa się siarkę występującą w węglu w postaci pirytu (siarczek żelaza) oraz w postaci siarki organicznej, chemicznie związanej z węglem. Natomiast odpirytowanie węgla może się odbywać metodą flotacyjną bądź grawitacyjną. Pierwsza powoduje usunięcie około $40 \%$ siarczku żelaza zawartego w węglu, w drugiej usuwa się do $80 \%$ siarki pirytowej. Uzyskany w ten sposób siarczek żelaza może służyć do produkcji kwasu siarkowego i czystego żelaza.

Istnieją również inne metody ochrony powietrza, które - choć rzadziej stosowane - także zasługują na krótką charakterystykę. Pierwsza z nich to dezodoryzacja gazów odlotowych, polegająca na częściowym utlenieniu, usunięciu grupy funkcyjnej lub na innej modyfikacji budowy cząsteczki odorantu. Odór można likwidować za pomocą utleniania ozonem lub chlorem.

Kolejną metodą jest biodegradacja, czyli biologiczny rozkład, za sprawą którego dochodzi do likwidacji substancji zanieczyszczających podatnych na ten proces, wykazujących rozpuszczalność w wodzie i wolnych od domieszek trujących dla mikroorganizmów. Do przeprowadzenia procesu biologicznego oczyszczania gazów służą płuczki biologiczne i biofiltry.

Techniki membranowe znalazły zastosowanie w usuwaniu par rozpuszczalników organicznych zanieczyszczających powietrze i gazy odlotowe. Wykorzystuje się tu różnicę ciśnienia, stężenia, temperatury lub potencjału elektrycznego po obu stronach membrany. Separacja składników zachodzi wskutek różnicy w prędkości transportu.

Niezależnie od przyjętej metody w procesach stosowanych do oczyszczania gazów odlotowych z zanieczyszczeń gazowych następują przede wszystkim: odsiarczanie, usuwanie tlenków azotu oraz usuwanie innych gazowych zanieczyszczeń, takich jak węglowodory, par rozpuszczalników, fluoru, chloru i ich organicznych pochodnych. 


\subsection{Urządzenia oczyszczające}

Ze względu na stan skupienia oddzielanych zanieczyszczeń urządzenia oczyszczające stosowane w ochronie powietrza dzieli się zwykle na urządzenia służące do:

- oddzielania z gazu rozdrobnionych zanieczyszczeń stałych (pyłu), zwane odpylaczami;

- oddzielania kropelek cieczy (mgief);

- redukcji zanieczyszczeń gazowych.

Odpylanie to sucha metoda elektrostatyczna przeznaczona do usuwania cząstek pyłu z wykorzystaniem różnego rodzaju sił i pola, które działając na cząstki ciała stałego, powodują ich ruch i wydzielenie ze strumienia gazu. Odpylacze są urządzeniami służącymi do tego celu. Znane są różne rodzaje odpylaczy suchych, a najbardziej znane to odpylacze: grawitacyjno-inercyjne, cyklony, elektrofiltry oraz filtry. W odpylaczach grawitacyjno-inercyjnych odpylanie zachodzi w wyniku działania sił grawitacyjnych w komorze osadczej, a opadające cząstki gromadzą się na jej dnie. Urządzenia te mają wiele zalet, przy czym najistotniejsze to prostota działania i konstrukcji, brak części ruchomych i niewielkie zapotrzebowanie na energię.

Filtry pyłowe umożliwiają odpylanie poprzez zatrzymanie pyłów na przegrodach filtracyjnych. Wyróżniamy filtry tkaninowe, włókniste i warstwowe. Filtry kominowe filtrują zanieczyszczenia unoszące się razem z dymem i szybko się zużywają. Najczęściej stosowanym filtrem kominowym jest elektrofiltr, który wykorzystuje siłę elektrostatyczną działającej na cząsteczki pyłu.

Elektrofiltry służą do usuwania pyłu z gazu technologicznego z wykorzystaniem siły elektrostatycznej działającej na cząstki tego pyłu. Stosowane są na ogół do oczyszczania bardzo dużych ilości gazów i spełniają bardzo wysokie wymagania odnośnie stopnia odpylania (powyżej 99,8\%). Można wymienić wiele zalet elektrofiltrów, w tym: możliwość odpylania w sposób ciągły bez znacznych ilości spalin, dużą sprawność wstrzymywania pyłów, prostotę budowy, a także małą ilość części ruchomych w urządzeniu. Nie są one jednak wolne od wad, żeby wymienić tylko duży koszt ich wytwarzania, a także znaczną czułość na zmiany 
natężenia przypływów odpylanych spalin, na zmiany temperatury i wilgotności spalin oraz na zmiany charakterystyki pyłu.

Odpylacz cyklonowy, potocznie zwany cyklonem, jest wykorzystywany do oczyszczania gazów z cząsteczek stałych. W tym urządzeniu zanieczyszczony gaz wprowadzany jest do cylindrycznej komory, a następnie w niej wiruje. W efekcie znajdujące się w gazie cięższe od niego cząsteczki są odrzucane na zewnątrz pod działaniem siły odśrodkowej. Skuteczność odpylania w cyklonach wzrasta wraz ze wzrostem prędkości wlotowej, a także wraz ze skracaniem promienia komory. Niekiedy cyklony łączone są w całe baterie cyklonów i multicyklonów.

Bardzo popularną techniką jest także odpylanie mokre, działające na zasadzie wymywania pyłów za pomocą cieczy, w którym wykorzystuje się zjawisko wytrącania cząstek ciał stałych w trakcie kontaktu z powierzchnią cieczy. Odpylacze mokre mają bardziej zwartą konstrukcję niż suche, przy tej samej wydajności odpylacza, niższe nakłady inwestycyjne i koszty eksploatacyjne. Przykładem urządzenia używanego do mokrego usuwania z gazu cząstek pyłu jest skruber, w którym to gaz przepłukiwany jest przez strugę kropel. Stosowane są również rozwiązania hybrydowe, które łączą metody suche i mokre. Jednym z takich rozwiązań jest elektrofiltr mokry.

Skuteczność działania urządzeń oczyszczających, określana jako stopień redukcji zanieczyszczeń, jest wielkością charakterystyczną dla urządzeń i wskazuje, jaki procent całkowitej ilości danego zanieczyszczenia wprowadzonego do urządzenia został przez to urządzenie zatrzymany. Wskaźnik ten wyraża się procentowym stosunkiem ilości zanieczyszczenia zatrzymanego do ilości zanieczyszczenia wytworzonego, tj. zatrzymanego i wyemitowanego. Im bliższa jest $100 \%$, tym większy jest potencjał ochronny danego źródła zanieczyszczeń.

Istnieje możliwość poprawy skuteczności elektrofiltrów poprzez (1) zwiększenie rozmiaru istniejącego elektrofiltru (w praktyce oznacza to kosztowną modernizację lub wymianę elektrofiltru na większy) lub (2) zastosowanie instalacji kondycjonowania spalin. Przed wyborem danej opcji modernizacji elektrofiltru należy wziąć pod uwagę przede wszystkim czynnik ekonomiczny. Często w wypadku starych elektrofiltrów zastosowanie nowego systemu zasilania i sterowania oraz wprowadzenie kilku korekt umożliwia znaczne podwyższenie skuteczności tych urządzeń bez ich powiększenia. 
Tabela 7.1. Liczba urządzeń chroniących atmosferę przed emisją zanieczyszczeń zainstalowanych w kotłowniach w Polsce w latach 2012-2014 (w szt.)

\begin{tabular}{|c|c|c|c|}
\hline Rok & $\begin{array}{c}\text { Instalacje } \\
\text { odsiarczania }\end{array}$ & $\begin{array}{c}\text { Urządzenia } \\
\text { odpylające }\end{array}$ & $\begin{array}{c}\text { Palniki } \\
\text { niskoemisyjne }\end{array}$ \\
\hline 2012 & 240 & 3342 & 3243 \\
\hline 2013 & 171 & 3066 & 3305 \\
\hline 2014 & 151 & 2833 & 3266 \\
\hline
\end{tabular}

Źródło: opracowanie własne na podstawie danych GUS².

Analiza danych GUS dotycząca liczby urządzeń zainstalowanych w kotłowniach w celu ochrony atmosfery przed zanieczyszczeniami pokazała, że w ostatnich latach systematycznie zmniejsza się w Polsce liczba instalacji odsiarczania oraz urządzeń odpylających. Natomiast liczba palników niskoemisyjnych ulegała w latach 2012-2014 nieznacznym wahaniom. Jako przyczyny można wskazać zmniejszający się w badanym okresie poziom uprzemysłowienia kraju oraz brak wystarczających środków finansowych na modernizację istniejących urządzeń lub zakup nowych.

\section{Literatura}

Banaś M (red.), Ochrona i inżynieria środowiska - Zrównoważony rozwój, Monografia, Zeszyt Nr 37, Wydział Inżynierii Mechanicznej i Robotyki AGH w Krakowie, Wydawnictwo AGH, Kraków 2008.

Dyrektywa Parlamentu Europejskiego i Rady 2010/75/UE z dnia 24 listopada 2010 r. w sprawie emisji przemysłowych - IED (zintegrowane zapobieganie zanieczyszczeniom i ich kontrola).

Janka R., Zanieczyszczenia pyłowe i gazowe, PWN, Warszawa 2014.

Jeż M., Technologie ochrony środowiska. Ochrona atmosfery, WSEiZ, Warszawa 2009.

Jędrusik M., Elektrofiltry: rozwinięcie wybranych technik podwyższania skuteczności odpylania, Oficyna Wydawnicza Politechniki Wrocławskiej, Wrocław 2008.

Konieczyński J., Ochrona powietrza przed szkodliwymi gazami: metody, aparatura $i$ instalacje, Politechnika Śląska, Gliwice 2004.

Kośmider J., Mazur-Chrzanowska B., Wyszyński B., Odory, Wydawnictwo Naukowe PWN, Warszawa 2002.

2 http://stat.gov.pl/obszary-tematyczne/srodowisko-energia/srodowisko/ochrona-srodowiska-2015,1,16.html. (data dostępu: 3 grudnia 2015 roku) 
Musialik-Piotrowska A., Rutkowski J., Aktualne problemy w ochronie powietrza atmosferycznego: praca zbiorowa, Polskie Zrzeszenie Inżynierów i Techników Sanitarnych, Sekcja Główna Ochrony Atmosfery, Warszawa 2008.

Rozporządzenie z 22 kwietnia 2011 r. w sprawie standardów emisyjnych z instalacji (Dz.U. z 2011 r. Nr 95, poz. 558).

Ustawa Prawo ochrony środowiska (Dz.U. z 2011 r. Nr 62, poz. 627 ze zmianami).

Urbaniak A., Zakrzewski P., Inteligentne systemy w inżynierii i ochronie środowiska, PZITS, Oddział Wielkopolski, Poznań 2007.

Warych J., Oczyszczanie gazów; procesy i aparatura, Wydawnictwa Naukowo-Techniczne, Warszawa 1998.

Zarzycki R., Imbierowicz M., Stelmachowski M., Wprowadzenie do inżynierii i ochrony środowiska, t. 1: Ochrona środowiska naturalnego, Wydawnictwa Naukowo-Techniczne, Warszawa 2007.

http://uranos.cto.us.edu.pl/ eco/pro/zzanw.html.

http://stat.gov.pl/sprawozdawczosc/.

http://www.imp.gda.pl/fileadmin/old_imp/ehd/efiltr00.pdf. http://www.gios.gov. pl/stansrodowiska/gios/pokaz_artykul/pl/front/stanwpolsce/srodowisko_i_ zdrowie/zanieczyszczenia_powietrz. 


\section{Rozdział 8}

\section{Inżynieria środowiska a ochrona litosfery Rekultywacja gleb}

\subsection{Wprowadzenie}

Na początku lat 70. XX wieku problem zanieczyszczenia litosfery w Europie stał się na tyle poważny, że konieczne było podjęcie licznych inicjatyw mających na celu ochronę, jak również rekultywację zanieczyszczonych terenów. Obecnie w tym zakresie wdrażanych jest (z pozytywnym skutkiem) wiele metod, w tym inżynieryjnych. W Polsce problem zanieczyszczenia gruntów jest postrzegany jako jeden z pilniejszych i wymagających natychmiastowych rozwiązań (na równi z ochroną wód i powietrza).

Ziemia, a w węższym znaczeniu gleba jest bardzo ważnym elementem środowiska przyrodniczego, gdyż razem z klimatem tworzy naturalne siedlisko roślin i zwierząt, spełniając ważną rolę przy produkcji biomasy, czyli żywej substancji organicznej przypadającej na określoną jednostkę powierzchni lub objętości. Na zanieczyszczenia litosfery wpływają pośrednio zanieczyszczenia pozostałych elementów środowiska, szczególnie wód i powietrza, jednakże ich źródłem jest przede wszystkim działalność człowieka, głównie przemysł i urbanizacja, komunikacja i rolnictwo oraz wszelkie niekorzystne dla stanu środowiska przekształcenia krajobrazu. Wśród wielu negatywnych skutków takiej działalności można wymienić niszczenie siedlisk różnych gatunków (np. puszczy tropikalnej i lasów), przeznaczanie kolejnych terenów pod zabudowę czy też przekształcenia w krajobrazie rolniczym w wyniku melioracji, intensyfikacji produkcji bądź wypalania traw. W konsekwencji może dochodzić do zmian mikroklimatu, a w dalszej kolejności do stepowienia i wyjaławiania gleb, jak również do wyginięcia niektórych gatunków.

\subsection{Degradacja gleby}

Grunty zdegradowane to takie grunty, których rolnicza lub leśna wartość użytkowa zmalała, w szczególności w wyniku: pogorszenia się warunków przyrodniczych, zmian środowiska, działalności przemysłowej, 
a także wadliwej działalności rolniczej'. Uznaje się je za nieprzydatne do określonego sposobu zagospodarowania bez wykonania działań rekultywacyjnych. Natomiast grunty zdewastowane to takie, które całkowicie utraciły wartość użytkową. Uznaje się je za nieprzydatne do żadnego sposobu zagospodarowania i są to zwykle powierzchnie pozbawione roślinności lub silnie skażone. Proces przywracania powierzchni biologicznie czynnych na powierzchniach zdewastowanych nazywamy rewitalizacją.

Degradacja może być efektem działalności człowieka (polegającej na eksploatacji kopalń, składowaniu odpadów przemysłowych lub komunalnych, zmianach sposobów użytkowania) lub zniszczenia terenu przez procesy geologiczne. Degradacja gleb to problem zarówno lokalny, jak i regionalny, bowiem skutki degradacji gleb wywierają znaczący wpływ na stan środowiska naturalnego w szerokim wymiarze przestrzennym.

Do najbardziej negatywnych pod względem stopnia zagrożenia dla zdrowia człowieka i środowiska skutków degradacji gleby można zaliczyć:

- zakwaszanie gleby, ponieważ kwaśna gleba uniemożliwia wzrost roślin;

- zmiany właściwości chemicznych gleby wynikające z chemicznego zanieczyszczenia;

- zniekształcenie i zniszczenie gleby;

- zatrucie gleby nadmiarem wszelkich związków, które trafiają do organizmów, a następnie do człowieka.

Wyróżniamy cztery podstawowe formy degradacji gleby: erozję, pustynnienie i stepowienie, zniekształcenie gruntów oraz chemiczne zanieczyszczenia gleb. Erozja jest procesem rozdrabniania i przemieszczania (zdzierania) wierzchniej warstwy gleby wskutek oddziaływania wiatru (wywiewanie gleby, deflacja) i wody (zmywanie gleby, erozja wgłębna). Występuje zwłaszcza w terenach górskich i pagórkowatych, pozbawionych lasu i na glebach ciężkich, tzn. z przewagą drobnych frakcji. Zapobieganie erozji gleb wymaga wykonywania zabiegów przeciwerozyjnych

1 Ustawa Ochrona gruntów rolnych i leśnych (Dz.U. z 2013 r., poz. 1205). 
o charakterze rolniczym i melioracyjnym, których celem jest zahamowanie spływu wód i przeciwdziałanie niszczycielskiej sile wiatru.

Pustynnienie i stepowienie to zjawisko spowodowane postępującym niedostatkiem wody w glebie i przyziemnej części atmosfery. Zniekształcenie gruntów oznacza niekorzystne zmiany budowy i właściwości powierzchni ziemi oraz stosunków wodnych na danym terenie. Natomiast chemiczne zanieczyszczenia gleb rozumiane są jako zachwianie równowagi chemicznej środowiska glebowego.

W celu ochrony gleby przed erozją najczęściej podejmowane są następujące działania (związane głównie z inżynierią ekologiczną):

- tarasowanie stromych stoków;

- prowadzenie dróg małymi spadami;

- zakładanie ochronnych pasów zieleni;

- budowanie progów na potokach w celu zmniejszenia prędkości spływu wody.

W przypadku degradacji terenu dalsze postępowanie uzależnione jest od sposobu jego użytkowania obecnie i w przyszłości oraz od rodzaju zanieczyszczeń, które spowodowały degradację. Należy wybrać optymalną technologię, która pozwoli przywrócić porządek na terenie zdegradowanym oraz jego pierwotne właściwości, szczególnie pod względem czystości gruntów i znajdujących się tam wód podziemnych. Przy wyborze metod i sposobów dalszego zagospodarowania terenów zdegradowanych należy wziąć pod uwagę kilka czynników, takich jak: jakość gruntów lub zwałowanego materiału, ich skład chemiczny i mineralogiczny, kształt zwału, zagłębienia oraz ich budowę.

\subsection{Rekultywacja gleb}

Działania naprawcze w środowisku przyrodniczym to wszelkie działania podejmowane w celu naprawy lub zastąpienia w równoważny sposób elementów przyrodniczych lub ich funkcji, które uległy uszkodzeniu ${ }^{2}$. Inżynieria środowiska jako dyscyplina naukowa stosowana wypracowała w tej materii wiele rozwiązań i propozycji, takich jak:

2 Zmiana ustawy - Prawo ochrony środowiska oraz niektórych innych ustaw (Dz.U. z 2014 r., poz. 1101). 
- ograniczenie emisji zanieczyszczeń przemysłowych i komunikacyjnych;

- przywracanie prawidłowych stosunków wodnych, przeciwdziałanie przesuszeniu i zawodnieniu gleb;

- budowanie bezpiecznych składowisk odpadów i wysypisk śmieci;

- minimalizacja erozji wodnej i wiatrowej;

- przeciwdziałanie chemicznej degradacji gleb przez zanieczyszczenia przemysłowe, motoryzacyjne czy nawożenie mineralne;

- ograniczenie do niezbędnego minimum technicznych deformacji gruntu i mechanicznego zanieczyszczenia gleby;

- rekultywacja gleb zdegradowanych.

Rekultywacja to szereg zabiegów, które mają przywrócić terenom zdegradowanym wartości użytkowe i przyrodnicze. W prawie polskim rekultywacja dotyczy trzech podstawowych elementów środowiska. Po pierwsze, będzie to rekultywacja przekształconego naturalnego ukształtowania terenu, która polega na przywróceniu go do staniu poprzedniego. Po drugie, rekultywacja gleby lub ziemi, która polega na przywróceniu ich właściwości do stanu wymaganego standardami jakości. Standardy te określają zawartość niektórych substancji w glebie albo ziemi, poniżej których żadna z funkcji pełnionych przez powierzchnię ziemi nie jest naruszona ${ }^{3}$. Natomiast rekultywacja gruntów (zdegradowanych albo zdewastowanych) rozumiana jest jako nadanie lub przywrócenie tym gruntom wartości użytkowych lub przyrodniczych przez właściwe ukształtowanie rzeźby terenu, poprawienie właściwości fizycznych i chemicznych, uregulowanie stosunków wodnych (głównie zabezpieczenie dyspozycyjnych zasobów wód gruntowych), odtworzenie gleb, umocnienie skarp oraz odbudowanie lub zbudowanie niezbędnych dróg ${ }^{4}$.

Rozróżniamy trzy fazy rekultywacji terenów zdegradowanych. Pierwsza z nich - przygotowawcza - jest istotnym etapem opracowania strategii rekultywacji dla danego terenu. Polega na rozpoznaniu występujących zanieczyszczeń pod kątem danej grupy, składu chemicznego

3 Ustawa Prawo ochrony środowiska (Dz.U. z 2006 r. Nr 129, poz. 902).

4 Ustawa Ochrona gruntów rolnych i leśnych (Dz.U. z 2013 r., poz. 1205). 
i związanych z tym określonych właściwości, takich jak rozpuszczalność w wodzie i innych rozpuszczalnikach, stężenie, lotność, podatność na degradację i biodegradację czy też pochodzenie. Czynniki te są bardzo ważne, ponieważ wpływają zarówno na efektywność, jak i koszty operacji oczyszczania lub neutralizacji nagromadzonych w glebie zanieczyszczeń. Na tym etapie należy także zbadać przyczyny oraz skutki degradacji i ustalić kierunki dalszego zagospodarowania terenów zdegradowanych.

Drugi etap, czyli rekultywacja techniczna, obejmuje przede wszystkim:

- ukształtowanie rzeźby terenu, które realizuje się przez wypełnienie zagłębień lub uformowanie zwałów w nawiązaniu do otaczającego terenu (może to być np. zasypywanie wyrobisk w sposób możliwie najkorzystniejszy dla przyszłego zagospodarowania tego terenu);

- wyrównanie powierzchni zwałów oraz nadanie zboczom nachyleń zapewniających stateczność skarp;

- właściwe ukształtowanie warunków wodnych (chodzi tu np. o gospodarkę wodami powierzchniowymi na terenie rekultywowanym i w jego sąsiedztwie oraz zabezpieczenie skarp przed erozją);

- całkowite lub częściowe odtworzenie gleby dzięki wykorzystaniu zwałowanych gruntów (niezbędne szczególnie w sytuacji, gdy trzeba odizolować odpady niebezpieczne);

- neutralizację gruntów toksycznych i użyźnianie jałowych, aby szkodliwe substancje nie były już groźne dla życia roślin i organizmów glebowych;

- dekoncentrację (rozrzedzenie) - tzn. wymieszanie gleby skażonej z glebą nieskażoną na dużej powierzchni;

- budowę infrastruktury niezbędnej do prawidłowego funkcjonowania rekultywowanego terenu.

Rekultywacja biologiczna stanowi trzecią fazę i polega na uzupełnieniu zabiegów mechanicznych rolniczymi, dzięki którym można wzbogacić glebę w niezbędne do życia roślin składniki pokarmowe.

Podejmowane są w tym względzie następujące działania: 
- nawożenie - organiczne, mineralne lub nawozami zielonymi;

- zabezpieczenie stateczności zboczy obudową biologiczną,

- regulacja lokalnych stosunków wodnych poprzez budowę urządzeń melioracyjnych i ochronę wód przed zanieczyszczeniem;

- przeciwerozyjna zabudowa roślinności, związana z przywróceniem siedlisk roślin (np. wprowadzenie roślinności pionierskiej);

- magazynowanie wody $\mathrm{w}$ dołach poeksploatacyjnych przeznaczonych na zbiorniki wodne.

Rola roślinności w procesach rekultywacji jest szczególnie istotna i polega na stabilizacji luźnych utworów gruntowych, zabezpieczeniu przed erozją wodną i powietrzną, ochronie terenów przed zanieczyszczeniami przemysłowymi, a także inicjowaniu i stymulowaniu procesów glebotwórczych (głównie dzięki roślinom trawiastym i motylkowym).

Wśród metod rekultywacji gleb można wyróżnić metody fizyko-chemiczne, biologiczne i termiczne. Kiedy stosowane są one bezpośrednio na terenie, gdzie wystąpiło zanieczyszczenie lub skażenie, to określa się je jako metody in situ. Natomiast metody ex situ wymagają przemieszczenia zanieczyszczonych gruntów lub przepompowania zanieczyszczonej wody w miejsce przeznaczone do ich oczyszczenia poza miejscem wystąpienia zanieczyszczenia. Zarówno jedne, jak i drugie dzielą się na metody: fizyczne, chemiczne i biologiczne. Poniżej przedstawiono charakterystykę wybranych metod.

Do fizycznych metod rekultywacji gleb są zaliczane wszystkie te metody, które nie zmieniają fizykochemicznych właściwości zanieczyszczeń nagromadzonych w oczyszczanej glebie. Jedną z bardziej znanych i dopracowanych technik jest spalanie, które polega na umieszczeniu zanieczyszczonej gleby w komorze spalania, gdzie w temperaturze $850-1200^{\circ} \mathrm{C}$ następuje rozkład termiczny szkodliwych związków. Oprócz wielu zalet metoda ma także wady, ponieważ gdy w pozostałości po spalaniu znajdują się metale ciężkie, mogą się one ulatniać razem z gazami, ponadto $w$ samym procesie mogą powstawać toksyczne związki - dioksyny.

Metody termiczne (spalanie i piroliza) są szczególnie przydatne do rekultywacji gleb obciążonych zanieczyszczeniami organicznymi, ale również do eliminacji z gleby niektórych metali ciężkich. Piroliza 
w porównaniu ze spalaniem jest technicznie bardziej skomplikowana i generuje więcej uciążliwych produktów ubocznych. Trzeba jednak pamiętać, że przy termicznej metodzie niszczone są również naturalne składniki organiczne gleby i jest to poważna wada jej zastosowania.

Metody hydrogeologiczne polegają na tworzeniu jednego lub kilku lejów depresyjnych w horyzontach wód podziemnych za pomocą studni czerpalnych. Tylko w połączeniu z innymi technikami rekultywacji, na przykład z oczyszczaniem wypompowanej, skażonej wody i jej powtórnym wprowadzeniem do gruntu, stanowią pełnowartościową metodę rekultywacji gruntów skażonych.

Technika odsysania powietrza z gruntu nadaje się do usuwania z gleby związków łatwo lotnych i jest stosowana w szerokim zakresie do rekultywacji nienasyconej warstwy gleby z węglowodorów chlorowcowanych i alifatycznych. Skuteczność techniki zależy jednak w dużym stopniu od rodzaju podłoża.

Metoda ekranowania ma na celu przerwanie drogi rozprzestrzeniania się emisji, natomiast nie zmienia chemicznych i fizycznych właściwości terenu skażonego. Immobilizacja zanieczyszczeń w gruncie następuje przez przekształcenie szkodliwych zanieczyszczeń w związki trudno rozpuszczalne lub przez ich związanie w materiale zestalającym. Materiałami wiążącymi mogą być: cement, wapień, krzemiany i organiczne polimery. Immobilizacja jest tym trudniejsza, im więcej różnego rodzaju zanieczyszczeń występuje równocześnie, gdyż jeden środek wiążący z reguły nie zestala równie dobrze wszystkich zanieczyszczeń.

Proces mechanicznego oddzielenia zanieczyszczonej gleby polega na selektywnym oddzieleniu poszczególnych jej frakcji. Do tego celu wykorzystywane są różne techniki, stosowane od wielu lat na przykład w gospodarce odpadami komunalnymi, a najczęściej:

- rozdzielanie grawitacyjne, polegające na wykorzystaniu różnic w gęstości poszczególnych frakcji;

- rozdzielanie na cyklonach;

- rozdzielanie magnetyczne, polegające na wykorzystaniu zjawiska indukcji magnetycznej.

Metody te mogą znacząco zredukować objętość zanieczyszczonej gleby, która w dalszym etapie poddawana jest oczyszczaniu inną metodą. 
Elektrooczyszczanie sprowadza się do wykorzystania zjawiska migracji zanieczyszczeń w polu elektrycznym wytworzonym w oczyszczanej glebie. To praktycznie jedyna metoda, za pomocą której można usunąć jednocześnie wiele metali ciężkich $w$ warunkach in situ. Jednak wciąż nie jest ona dostatecznie dopracowana. Jej zastosowanie wiąże się z poważnym zakwaszeniem gleby, a procesy redoks powodują powstawanie niepożądanych związków.

Odmywanie zanieczyszczonej gleby pozwala na usunięcie przede wszystkim zanieczyszczeń nieorganicznych, ale także niektórych typów zanieczyszczeń organicznych. Jest to wysoce efektywna, szybka i dobra metoda oczyszczania silnie zanieczyszczonych gleb. Wśród jej wad wskazuje się: koszty związane z koniecznością budowy specjalnej instalacji i jej eksploatacją, generowanie dużej ilości odpadów, wysoki stopień inwazyjności środowiskowej oraz często sprzeciw społeczny wobec budowy instalacji w sąsiedztwie.

Immobilizacja zanieczyszczeń ex situ jest metodą neutralizacji niektórych zanieczyszczeń organicznych i nieorganicznych obecnych w glebie za pomocą substancji wiążących. Metoda ta jest łatwa w aplikacji i znajduje zastosowanie nawet przy bardzo dużej toksyczności zanieczyszczeń. Wymaga stosunkowo niewielkich kosztów inwestycyjnych i operacyjnych. Metoda cechuje się jednak wysoką inwazyjnością w stosunku do środowiska, między innymi generuje dużą ilość odpadów stałych, które powinny być składowane na specjalnie przystosowanym do tego celu składowisku.

Chemiczne i fotochemiczne procesy utleniania i redukcji pozwalają na całkowitą mineralizację nagromadzonych w glebie zanieczyszczeń organicznych lub efektywne przekształcenie zanieczyszczeń, w tym także nieorganicznych w formy nietoksyczne lub mniej toksyczne. Stosowanymi tu odczynnikami są: ozon, nadtlenek wodoru, chlorany, tlenki chloru i inne. W wypadku procesu fotochemicznego czynnikiem dodatkowym jest także promieniowanie ultrafioletowe. Metoda nie wymaga specjalnych instalacji, może być użyta także do oczyszczania wód podziemnych, cechuje się niskimi kosztami operacyjnymi oraz szerokim zakresem zastosowania do wielu rodzajów i typów zanieczyszczeń. Ze względu na wykorzystywanie silnych utleniaczy, które są silnie żrące i często wybuchowe, metoda jest jednak inwazyjna dla środowiska i wymaga zachowania szczególnych zasad bezpieczeństwa.

Metoda kompostowania jest metodą biologiczną i polega na wydobyciu zanieczyszczonej gleby i zmagazynowaniu jej w formie pryzmy 
kompostowej lub rozmieszczeniu na większej powierzchni cienką warstwą. Proces jest prowadzony przy udziale aerobowych mikroorganizmów, które mineralizują związki organiczne do związków prostych lub przekształcają w formy nieszkodliwe dla środowiska. Metoda jest nieskomplikowana i relatywnie tania, nie wymaga specjalistycznej aparatury, kontroli procesu ani wyszkolonego personelu. Jednakże potrzebuje dużo czasu i znacznej powierzchni. Jest też mało efektywna przy usuwaniu niektórych grup związków organicznych, a ponadto ma bardzo ograniczone zastosowanie w odniesieniu do zanieczyszczeń nieorganicznych.

Do biologicznych metod oczyszczania gleb zaliczana jest fitoremediacja. W metodzie tej wykorzystuje się właściwości niektórych gatunków roślin zdolnych do pobierania z gleby i gromadzenia w tkankach zanieczyszczeń, w ilościach nawet stukrotnie wyższych od spotykanych w tkankach innych roślin. Metoda ta najlepiej sprawdza się na terenach zanieczyszczonych metalami ciężkimi oraz ksenobiotykami.

Bioremediacja jest techniką, która wykorzystuje naturalne mikroorganizmy glebowe lub specjalnie wyselekcjonowane oraz genetycznie zmodyfikowane grupy mikroorganizmów w procesach rozkładu zanieczyszczeń organicznych do związków mniej toksycznych lub nietoksycznych.

Do najnowszych inżynierskich metod i technologii, będących często jeszcze na etapie prób, są zaliczane: fotoliza, proces mieszany, rozkład w temperaturze plazmy, stabilizacja zanieczyszczeń na polimerach czy też nitryfikacja. Fotoliza może być stosowana do oczyszczania gleb zanieczyszczonych substancjami organicznymi. Jest to metoda mało inwazyjna z punktu widzenia środowiska, a produkty rozkładu zanieczyszczeń na ogół nie są toksyczne. Nie można wykorzystać tej metody do rekultywacji gleb zanieczyszczonych metalami ciężkimi i innymi zanieczyszczeniami mineralnymi, a przy ograniczonym dostępie światła konieczne jest wprowadzenie źródła promieniowania UV.

W procesie mieszanym usuwanie zanieczyszczeń z gleby polega na wykorzystaniu zjawiska elektroosmozy. Zanieczyszczenia organiczne, nieorganiczne i mieszane są wyłapywane w odpowiednio przygotowanych warstwach, a następnie są unieszkodliwiane po adsorpcji i wydobyciu z gruntu odrębnymi metodami. Wadą tej metody jest to, że powoduje obumarcie organizmów żywych znajdujących się między elektrodami.

Neutralizacja zanieczyszczeń w temperaturze plazmy jest procesem fizykochemicznym polegającym na termicznym rozkładzie niebezpiecznych związków organicznych w wysokiej temperaturze łuku plazmowego. 
Metoda nie eliminuje natomiast metali ciężkich, a wysoka temperatura powoduje jednocześnie powstawanie dużych ilości tlenków azotu, które należy usunąć $w$ dalszym etapie ze spalin. Koszty eksploatacyjne rozkładu w temperaturze plazmy są znacznie wyższe niż koszty spalania.

Stabilizacja zanieczyszczeń na polimerach sprowadza się do zastosowania polimerów pochodzenia mikrobiologicznego w warstwie podpowierzchniowej zanieczyszczonego metalami ciężkimi oraz substancjami chemicznymi gruntu. Metoda polega na adsorpcji zanieczyszczeń, głównie metali ciężkich i ich związków oraz innych substancji chemicznych na specjalnie wykonanych matach. Jest to przykład metody ekologicznej z powodu jej nieinwazyjności oraz stosowania substancji pochodzenia naturalnego. Zarówno metoda z użyciem plazmy, jak i stabilizacja są nadal w stadium prób, zatem w ich ocenie należy uwzględnić brak całkowitej pewności co do skuteczności i efektywności.

Witryfikacja zanieczyszczeń w glebie jest procesem fizykochemicznym polegającym na wykorzystaniu zjawiska stapiania materiału glebowego pod wpływem ciepła w temperaturze około $2800^{\circ} \mathrm{C}$, wydzielającego się $\mathrm{w}$ wyniku przepływu prądu elektrycznego przez materiał glebowy o dużej oporności. Może być stosowana do rekultywacji gleb silnie zanieczyszczonych metalami ciężkimi oraz azbestem. Umożliwia zmianę rodzaju odpadu z odpadu niebezpiecznego, jaki stanowi silnie zanieczyszczona gleba, na odpad obojętny. Metoda ta jest jednak bardzo kosztowna.

\subsection{Technologie przeróbki odpadów komunalnych}

Gospodarka odpadami komunalnymi należy do kluczowych zagadnień inżynierii środowiska. Sektor ten jest w znacznym stopniu związany z problematyką ochrony gleb, szczególnie ze względu na kwestię bezpiecznego dla środowiska unieszkodliwiania i składowania odpadów niewykorzystanych. Wprawdzie od wielu lat podejmowane są liczne działania zmierzające do tego, aby gospodarka odpadami w Polsce odbywała się w sposób bardziej zrównoważony, jednak wciąż jest na tym polu wiele do zrobienia, głównie w zakresie przestrzegania hierarchii postępowania z odpadami. Dlatego też zagospodarowanie odpadów komunalnych to aktualnie jeden z najważniejszych problemów inżynierii środowiska.

W wielu unijnych i krajowych dokumentach strategicznych zaleca się wdrażanie w gospodarce odpadami technologii środowiskowych 
oraz stosowanie innowacyjnych metod inżynieryjnych, które mają na celu przede wszystkim ograniczenie ilości odpadów nieprzetworzonych, a przez to efektywniejszą ochronę gleby. Inżynieria środowiska wspomaga rozwój zrównoważonej gospodarki odpadami, między innymi proponując rozwiązania pozwalające na wtórne wykorzystywanie surowców, którym można przywrócić pierwotne właściwości po ich poddaniu odpowiednim procesom regeneracyjnym.

Wytwarzanie odpadów i gospodarowanie nimi nazywamy gospodarką odpadami. Przez gospodarowanie odpadami rozumie się zbieranie, transport, przetwarzanie odpadów, łącznie z nadzorem nad tego rodzaju działaniami, jak również późniejsze postępowanie z miejscami unieszkodliwiania odpadów oraz działania wykonywane w charakterze sprzedawcy odpadów lub pośrednika w obrocie odpadami.

Dyrektywa w sprawie odpadów z 2008 r. ${ }^{5}$ wprowadziła następującą hierarchię sposobów postępowania z odpadami:

- zapobieganie powstawaniu odpadów;

- przygotowanie do ponownego użycia;

- recykling;

- inne procesy odzysku;

- unieszkodliwianie.

W związku z tym jednym z głównych celów systemu gospodarki odpadami jest minimalizacja ilości uzyskiwanych odpadów w miejscu ich powstawania. Na znaczeniu coraz bardziej zyskują procesy recyklingu, które umożliwiają odzysk podstawowych surowców i ich ponowne wykorzystanie. Najmniej racjonalnym i pożądanym procesem jest gromadzenie odpadów na składowiskach.

W gospodarce odpadami należy stosować technologie zgodne z koncepcją zrównoważonego rozwoju, w tym z modelem zielonej gospodarki oraz gospodarki o obiegu zamkniętym. Przede wszystkim powinny być to nisko odpadowe technologie produkcji zapewniające wykorzystanie możliwie wszystkich składników użytych surowców. Instalacje oraz urządzenia do przetwarzania odpadów należy stosować

5 Dyrektywa Parlamentu Europejskiego i Rady 2008/98/WE z dnia 19 listopada 2008 r. w sprawie odpadów oraz uchylająca niektóre dyrektywy (Dz.Urz. L 312 z 22.11.2008 r.). 
wówczas, gdy spełniają wymagania ochrony środowiska oraz gdy pozostałości powstające w wyniku działalności związanej z przetwarzaniem odpadów będą przetwarzane z zachowaniem wymagań określonych w prawie.

Podstawą technologii bezodpadowej jest niedopuszczenie do powstawania odpadów oraz pełne i kompleksowe wykorzystanie surowca. Stanowi ona pewien układ procesów technologicznych związanych z wydobywaniem i kompleksowym przetwarzaniem surowców na wyroby $w$ taki sposób, aby wyeliminować odpady. Natomiast w razie braku możliwości ich całkowitego wyeliminowania, należy zapewnić ich zagospodarowanie zgodnie z zasadami ochrony środowiska naturalnego.

Istnieją trzy główne metody odzysku opakowań poużytkowych: spalanie z odzyskiem energii, kompostowanie i recykling. Przekształceniu termicznemu przez spalanie powinny być poddane przede wszystkim opakowania poużytkowe, dla których recykling nie jest uzasadniony technologicznie i ekonomicznie, a które charakteryzują się dużą wartością opałową. Główną zasadą działania recyklingu jest maksymalizacja ponownego wykorzystania tych samych materiałów z jednoczesną minimalizacją nakładów na ich przetworzenie. Dzięki takiemu podejściu bardziej chronione są surowce, które służą do wytworzenia oraz późniejszego przetworzenia tych materiałów. Technologie spalania nowej generacji spełniają obecnie wymagania w zakresie dopuszczalnych poziomów emisji szkodliwych substancji. Kompostowanie jest procesem przetwarzania materiałów na nawóz zwany kompostem, a zachodzi pod wpływem działania bakterii oraz grzybów.

Należy jednak stwierdzić, że każda ze wspomnianych wyżej metod unieszkodliwiania odpadów komunalnych ma zarówno zalety, jak i wady. Żadna z nich nie umożliwia całkowitej likwidacji odpadów, dlatego składowanie pozostałości po stosowaniu różnych metod jest obecnie konicznością. Ponadto w metodach unieszkodliwiania całej masy odpadów zawsze powstają odpady wtórne, które także należy poddać procesom unieszkodliwiania. Natomiast w przypadku unieszkodliwiania odpadów zmieszanych, o bardzo różnorodnym składzie, zastosowanie jednej metody nie może zapewnić ich pełnego unieszkodliwienia. W związku z tym należy stosować metody kompleksowe i zintegrowane, z wykorzystaniem kilku technologii, które w odpowiednio dobranym zestawie pozwalają zminimalizować ilość końcowych produktów unieszkodliwiania i ich negatywne oddziaływanie 
na środowisko, a także dostosować pracę instalacji do warunków zewnętrznych.

Analiza danych GUS odnośnie metod gospodarowania odpadami w Polsce w ostatnich latach wykazała wzrost ilości odpadów przeznaczonych do recyklingu oraz przekształcenia termicznego (tab. 8.1). Jednocześnie, zgodnie $z$ aktualnymi unijnymi wymaganiami w tym względzie, zmalała ilość odpadów deponowanych na składowiskach. Około $44 \%$ ogólnej ilości zebranych w 2014 roku odpadów komunalnych przeznaczono do odzysku, natomiast do recyklingu $21,1 \%$. W 2014 roku do unieszkodliwienia skierowano łącznie 5834,9 tys. ton odpadów, z czego $52,6 \%$ odpadów zebranych ogółem przeznaczono do składowania, a 3,9\% do unieszkodliwienia poprzez przekształcenie termiczne bez odzysku energii.

Tabela 8.1. Zagospodarowanie odpadów w Polsce w latach 2012-2014 (w tys. ton)

\begin{tabular}{|c|c|c|c|c|c|c|}
\hline \multirow{2}{*}{ Rok } & \multirow{2}{*}{ Ogółem } & \multicolumn{5}{|c|}{ Zebrane odpady komunalne } \\
\cline { 3 - 7 } & & \multicolumn{4}{|c|}{ operacji odzysku } & \multicolumn{2}{c|}{$\begin{array}{c}\text { operacji } \\
\text { unieszkodliwiania }\end{array}$} \\
\cline { 3 - 7 } & & $\begin{array}{c}\text { recy- } \\
\text { klingu }\end{array}$ & $\begin{array}{c}\text { komposto- } \\
\text { wania lub } \\
\text { fermentacji }\end{array}$ & $\begin{array}{c}\text { przekształcania } \\
\text { termicznego } \\
\text { z odzyskiem } \\
\text { energii }\end{array}$ & $\begin{array}{c}\text { przekształca- } \\
\text { nia termicz- } \\
\text { nego } \\
\text { bez odzysku } \\
\text { energii }\end{array}$ & $\begin{array}{c}\text { składowa- } \\
\text { nia }\end{array}$ \\
\hline 2012 & 9580900 & 1243,7 & brak danych & brak danych & brak danych & 7158,2 \\
\hline 2013 & 9473831 & 1498,6 & 1230,5 & 563,0 & 203,0 & 5978,7 \\
\hline 2014 & 10330409 & 2179,9 & 1153,6 & 1162,1 & 398,0 & 5436,9 \\
\hline
\end{tabular}

Źródło: opracowanie własne na podstawie danych GUS ${ }^{6}$.

Odgazowywanie składowisk jest obecnie procesem wymaganym przez prawo Unii Europejskiej. Dotyczy w szczególności tych składowisk, na których gromadzone są odpady biodegradowalne. Uzyskiwany gaz składowiskowy należy przede wszystkim poddać obróbce, a następnie wykorzystać do produkcji energii. W przypadku zbyt małej ilości gazu

6 http://stat.gov.pl/obszary-tematyczne/infrastruktura-komunalna-nieruchomosci/ nieruchomosci-budynki-infrastruktura-komunalna/infrastruktura-komunalna-w-2014-r-,3,12.html. (data dostępu: 8 listopada 2015 roku) 
zaleca się jego unieszkodliwienie, na przykład poprzez spalenie w palnikach lub pochodniach. W 2014 roku w Polsce były 342 składowiska wyposażone $w$ instalacje służące do odgazowywania i stanowiły one $86,8 \%$ ogółu czynnych składowisk odpadów komunalnych (tab. 8.2). W roku poprzednim ten odsetek wynosił $84,2 \%$. Spadek ogólnej liczby instalacji odgazowywania oraz instalacji z gazem w latach 2012-2014 spowodowany jest systematycznie zmniejszającą się ogólną liczbą funkcjonujących składowisk w Polsce, zgodnie $z$ aktualnymi wymaganiami unijnymi w tym względzie. W 2014 roku ponad 42\% instalacji do odgazowywania stanowiły instalacje z gazem uchodzącym bezpośrednio do atmosfery, $4,2 \%$ - instalacje, w których ujmowany gaz składowiskowy był unieszkodliwiany z odzyskiem energii cieplnej, a 16,4\% - takie, w których gaz składowiskowy został wykorzystany do produkcji energii elektrycznej. Należy zauważyć, że z każdym rokiem wzrasta liczba instalacji z gazem unieszkodliwianym przez spalanie. W 2014 roku w wyniku unieszkodliwienia poprzez spalanie ujętego gazu odzyskano około 81415 tys. MJ energii cieplnej (o 1\% mniej niż w 2013 r.) oraz około 148348 tys. kWh energii elektrycznej (o 9\% mniej niż w 2013 r.) ${ }^{7}$.

Tabela 8.2. Odgazowywanie składowisk kontrolowanych $w$ Polsce $w$ latach 2012-2014 (w szt.)

\begin{tabular}{|c|c|c|c|c|c|c|c|}
\hline \multirow{4}{*}{ Rok } & \multirow{2}{*}{\multicolumn{2}{|c|}{$\begin{array}{l}\text { Liczba składo- } \\
\text { wisk z instalacją } \\
\text { odgazowywania }\end{array}$}} & \multicolumn{5}{|c|}{ Liczba instalacji z gazem } \\
\hline & & & \multirow{3}{*}{$\begin{array}{l}\text { ucho- } \\
\text { dzącym } \\
\text { do at- } \\
\text { mosfery }\end{array}$} & \multicolumn{4}{|c|}{ unieszkodliwianym przez spalanie } \\
\hline & \multirow[b]{2}{*}{$\begin{array}{l}\text { ogó- } \\
\text { łem }\end{array}$} & \multirow[b]{2}{*}{$\begin{array}{l}\text { w tym: } \\
\text { na wsi }\end{array}$} & & \multicolumn{2}{|c|}{ bez odzysku energii } & \multicolumn{2}{|c|}{ z odzyskiem energii } \\
\hline & & & & $\begin{array}{l}\text { w palnikach } \\
\text { indywidual- } \\
\text { nych }\end{array}$ & $\begin{array}{c}\text { w po- } \\
\text { chodni } \\
\text { zbiorczej }\end{array}$ & cieplnej & $\begin{array}{c}\text { elektrycz- } \\
\text { nej }\end{array}$ \\
\hline 2012 & 430 & 319 & 244 & 63 & 81 & 13 & 58 \\
\hline 2013 & 363 & 264 & 199 & 61 & 78 & 15 & 59 \\
\hline 2014 & 342 & 245 & 159 & 59 & 82 & 16 & 62 \\
\hline
\end{tabular}

Uwaga: Łączna liczba instalacji może być większa od liczby składowisk ogółem, ponieważ na składowisku może być więcej niż jeden rodzaj instalacji odgazowywania.

Źródło: opracowanie własne na podstawie danych GUS ${ }^{8}$.

7 Infrastruktura komunalna w 2014 r., GUS, Warszawa 2015, s. 30.

8 http://stat.gov.pl/obszary-tematyczne/srodowisko-energia/srodowisko/ochrona-srodowiska-2015,1,16.html. (data dostępu: 4 grudnia 2015 roku) 
Metody stosowane w naszym kraju w gospodarce odpadami są na coraz wyższym poziomie technologicznym. Istnieją jednak bariery w ich wprowadzaniu, przede wszystkim jest to brak środków finansowych na szybszy rozwój przedsiębiorstw recyklingowych i zbyt niski poziom nakładów na badania w zakresie nowych technologii. Wprawdzie technologie recyklingu w Polsce są coraz efektywniejsze, jednak ich poziom jest daleki od osiągniętego w wielu innych krajach europejskich.

\section{Literatura}

Anigacz W., Żakowicz E., Ochrona środowiska, Politechnika Opolska, Opole 2003.

Buczkowski R., Kondzielski I., Szymański T., Metody remediacji gleb zanieczyszczonych metalami ciężkimi, Wydawnictwo UMK, Toruń 2002.

Cebula J., Oczyszczanie gleb i gruntów, Wydawnictwo Politechniki Śląskiej, Gliwice 2014.

Dyrektywa Parlamentu Europejskiego i Rady 2008/98/WE z dnia 19 listopada 2008 r. w sprawie odpadów oraz uchylająca niektóre dyrektywy (Dz.Urz. L 312 z 22.11.2008 r.).

Gworek B. i in., Technologie rekultywacji gleb, Instytut Ochrony Środowiska, Warszawa 2004.

Kacperski W.T., Inżynieria środowiska, t. 2: Gospodarka odpadami, Wydawnictwo Politechniki Radomskiej, Radom 2003.

Karczewska A., Ochrona gleb i rekultywacja terenów zdegradowanych, Uniwersytet Przyrodniczy, Wrocław 2008.

Kowalik P., Ochrona środowiska glebowego, Wydawnictwo Politechniki Gdańskiej, Gdańsk 1999.

Rosik-Dulewska C., Podstawy gospodarki odpadami, PWN, Warszawa 2013.

Siuta J., Żukowski B., Degradacja i rekultywacja powierzchni ziemi w Polsce - monografia, IOŚ, Warszawa 2008.

Ustawa z dnia 14 grudnia 2012 r. o odpadach (Dz.U. z 2013 r., poz. 21) z dnia 14 grudnia 2012 r., z późn. zmianami (Dz.U. z 2014 r., poz. 695, 1101, 1322).

Ustawa o zapobieganiu szkodom w środowisku i ich naprawie (Dz.U. z 2007 r. $\mathrm{Nr} 75$, poz. 493).

Ustawa Ochrona gruntów rolnych i leśnych (Dz.U. z 2013 r., poz. 1205).

Ustawa Prawo ochrony środowiska (Dz.U. z 2006 r. Nr 129, poz. 902).

Zarzycki R., Imbierowicz M., Stelmachowski M., Wprowadzenie do inżynierii $i$ ochrony środowiska, t. 1: Ochrona środowiska naturalnego, Wydawnictwa Naukowo-Techniczne, Warszawa 2007.

Zmiana ustawy - Prawo ochrony środowiska oraz niektórych innych ustaw (Dz.U. z 2014 r., poz. 1101). 
http://stat.gov.pl/obszary-tematyczne/infrastruktura-komunalna-nieruchomosci/ nieruchomosci-budynki-infrastruktura-komunalna/infrastruktura-komunalna-w-2014-r-,3,12.html.

http://stat.gov.pl/obszary-tematyczne/srodowisko-energia/srodowisko/ochrona-srodowiska-2015,1,16.html. 


\section{Rozdział 9}

\section{Ujęcia wód. Uzdatnianie wody}

\subsection{Ujęcia wód jako budowle wodne}

Główne zadania gospodarki wodnej spójne z zasadami zrównoważonego rozwoju dotyczą ochrony ekosystemów wodnych, wykorzystania wód w rozwoju społeczno-gospodarczym, a także przeciwdziałania skutkom naturalnych zagrożeń. Do realizacji tych zadań w zakresie technicznym służy inżynieria wodna, w tym głównie budownictwo wodne zajmujące się budowlami hydrotechnicznymi projektowanymi i wznoszonymi przez inżynierów budownictwa.

Budowle hydrotechniczne to budowle (wraz z urządzeniami i instalacjami technicznymi z nimi związanymi), które służą gospodarce wodnej oraz kształtowaniu zasobów wodnych i korzystaniu z nich'1. Wśród wielu budowli hydrotechnicznych są także ujęcia śródlądowych wód powierzchniowych i wyloty ścieków. Do budowli wodnych szczególnego znaczenia należą budowle związane z zaopatrzeniem w wodę oraz oczyszczaniem i odprowadzaniem wody zużytej, czyli na przykład ujęcia wody, stacje pomp, budowle do uzdatniania wody i oczyszczania ścieków.

Najogólniej można powiedzieć, że ujęcia wody służą do korzystania z zasobów wodnych występujących na Ziemi i są to zespoły urządzeń wraz z budowlami służącymi do pobierania wody dla wodociągów. Integralną część ujęcia może też stanowić wstępne oczyszczenie na kratach i sitach, lecz bez urządzeń do podnoszenia wody. Ujęcie wody pitnej powinno zapewniać utrzymanie odpowiedniej ilości ujmowanej i uzdatnianej wody, poprawiać jakość wody uzdatnionej i zapewniać jej stabilność, poprawiać sterowalność i kontrolę procesu technologicznego, a także obniżać energochłonność eksploatacji stacji. Według podstawowej klasyfikacji ujęć wody odnoszącej się do miejsca, z którego woda jest pobierana, ujęcia można podzielić na ujęcia wód podziemnych, wód powierzchniowych oraz ujęcia źródeł.

1 Rozporządzenie Ministra Środowiska z dnia 20 kwietnia 2007 r. w sprawie warunków technicznych, jakim powinny odpowiadać budowle hydrotechniczne i ich usytuowanie (Dz.U. z 2007 r. Nr 86, poz. 579). 
Ujęcia wód podziemnych to obiekty i urządzenia przeznaczone do zdrenowania warstw wodonośnych i czerpania z nich wody. Według najprostszej klasyfikacji dzielą się na pionowe (do których należą studnie) oraz poziome (np. systemy drenażowe). Inny podział wyróżnia ujęcia płytkich wód podziemnych za pomocą ciągów drenażowych lub galerii zbiorczej, ujęcia za pomocą studzien kopanych, wierconych, zespołu studzien wierconych lub studzien promienistych.

Ujęcia wód powierzchniowych można sklasyfikować w następujący sposób: ujęcia wód opadowych, wód powierzchniowych płynących (w tym ujęcia wód rzek średnich i dużych oraz wód potoków i małych rzek), ujęcia wód powierzchniowych stojących ze zbiorników naturalnych lub sztucznych. Konstrukcja ujęcia wód powierzchniowych zależy od rodzaju i cech charakterystycznych wody, topografii i układu terenu oraz wielkości wodociągu. Ujęcia wód powierzchniowych stanowią najczęściej obiekty inżynieryjne w postaci progów piętrzących, ale również obiekty zlokalizowane na brzegu rzeki lub jeziora, które wyposażono w system filtracji na złożu piaskowo-żwirowym. Piętrzenie wody znacznie ułatwia pobór wody w czasie tzw. niżówek, czyli okresów niewielkiego ilościowo spływu wody w cieku. Spiętrzona woda przepływa najpierw przez system krat zabezpieczających ujęcie przed grubymi zanieczyszczeniami do koryta i komory zbiorczej, a następnie przez odstojnik, w którym osiadają zanieczyszczenia drobne (np. piasek). W końcowym etapie woda wpływa do komory czerpalnej._

Systemy drenażowe instalowane są promieniście pod dnem rzeki, a odbiór wody z drenów zachodzi grawitacyjnie w centralnie usytuowanej studni szybowej. Taka metoda umożliwia usunięcie z wody glonów, bakterii, mętności, żelaza i manganu. Pozwala także zabezpieczyć ujęcie przed nagłymi zanieczyszczeniami wody (np. przed substancjami ropopochodnymi, utrzymującymi się zazwyczaj na powierzchni rzeki).

Ujęcia wód potoków i małych rzek mogą być źródłem zasilania wodociągów, ale tylko wówczas, gdy można stworzyć odpowiednią głębokość tego ujęcia, niezbędną dla poboru wody oraz dla zatrzymania materiału dennego. Jeżeli warunki lokalne na to pozwalają, ujęcia wody z potoków mogą być wykorzystywane również w postaci studni kopanej zapuszczonej w grunt wodonośny w korycie potoku. Ujęcie za pomocą progu spiętrzającego stosowane jest na potokach górskich i małych ciekach nizinnych, których koryto nie przekracza 15 cm, i wykorzystywane jest do pobierania małych ilości wody. 
Ujęcia źródeł to miejsca samorzutnego wypływu wód podziemnych na powierzchnię. Jeśli wydajność źródła jest znacząca i istnieje możliwość uwolnienia nadmiaru wody, to kieruje się ją do znajdującego się poniżej cieku wodnego. Najogólniej ujęcia ze źródeł dzieli się na: wstępujące, zstępujące, skupione i warstwowe.

\subsection{Metody uzdatniania wody}

Wodę z ujęć powierzchniowych i podziemnych należy poddać procesom uzdatniania, zanim skieruje się ją do systemów wodociągowych. Tylko w niektórych przypadkach wodę czerpaną wprost z ujęć podziemnych lub powierzchniowych można wykorzystywać z pominięciem tych działań. Uzdatnianie wody pitnej w celu zaopatrzenia w nią ludności podlega szczególnym procedurom technologicznym, przy czym woda przeznaczona do spożycia przez ludzi to woda:

- w stanie pierwotnym lub po uzdatnieniu - przeznaczona do picia, przygotowania żywności lub innych celów domowych - niezależnie od jej pochodzenia i od tego, czy jest dostarczana z sieci dystrybucyjnej, cystern, w butelkach lub pojemnikach;

- wykorzystywana przez przedsiębiorstwo produkcji żywności do wytworzenia, przetworzenia, konserwowania lub wprowadzania do obrotu produktów albo substancji przeznaczonych do spożycia przez ludzi.

Woda do picia i zastosowań gospodarczych powinna być przede wszystkim nieszkodliwa dla zdrowia człowieka i zwierząt, czysta oraz smaczna. Nie powinna zawierać dużej ilości bakterii, zawiesin, soli manganu i żelaza. Powinna natomiast zawierać w niewielkich stężeniach sole wapnia i magnezu, rozpuszczony $\mathrm{CO}_{2}$ oraz mikroelementy.

Jakość wody uzdatnionej kierowanej do sieci wodociągowych jest kontrolowana w sposób ciągły na podstawie analizy wartości kilkudziesięciu wskaźników fizykochemicznych, mikrobiologicznych i organoleptycznych wody. Nadzór nad jakością wody przeznaczonej do spożycia przez ludzi sprawują organy Państwowej Inspekcji Sanitarnej na zasadach określonych w przepisach o Państwowej Inspekcji Sanitarnej. Natomiast zastosowanie nowych technologii uzdatniania wody przeznaczonej do spożycia przez ludzi wymaga zgody państwowego wojewódzkiego inspektora sanitarnego. 
Do fizycznych wskaźników jakości wody zaliczamy: mętność, barwę, smak i zapach oraz temperaturę. Wskaźniki chemiczne to: odczyn, utlenialność, zawartość azotanów, chlorków, siarczanów, fosforanów, żelaza, manganu, krzemu, magnezu i wapnia, zasadowość, sucha pozostałość, rozpuszczone gazy itp. Wymóg jest taki, że w wyniku uzdatniania wody zostaną usunięte wszystkie substancje stanowiące zanieczyszczenia bądź stężenia zanieczyszczeń w końcowym produkcie będą bardzo małe. Wykorzystuje się do tego celu przede wszystkim metody mechaniczne (w tym usuwanie zawiesin i odgazowanie), chemiczne (np. odkwaszanie, usuwanie żelaza i manganu, zmiękczanie) oraz bakteriologiczne (głównie dezynfekcję wody).

Przykładowy schemat ciągu technologicznego uzdatniania wody do picia przedstawiono na rysunku 9.1. Woda ujmowana ze zbiornika wody powierzchniowej jest najpierw przepuszczana przez kraty i sita, następnie kierowana do osadnika, gdzie zachodzi proces sedymentacji zawiesin, po czym ponownie na filtry. Po procesie odżelaziania i odgazowania uzdatniana woda zostaje znów przefiltrowana w celu usunięcia z niej osadów. Ostatnim etapem uzdatniania jest dezynfekcja chlorem lub ozonem.

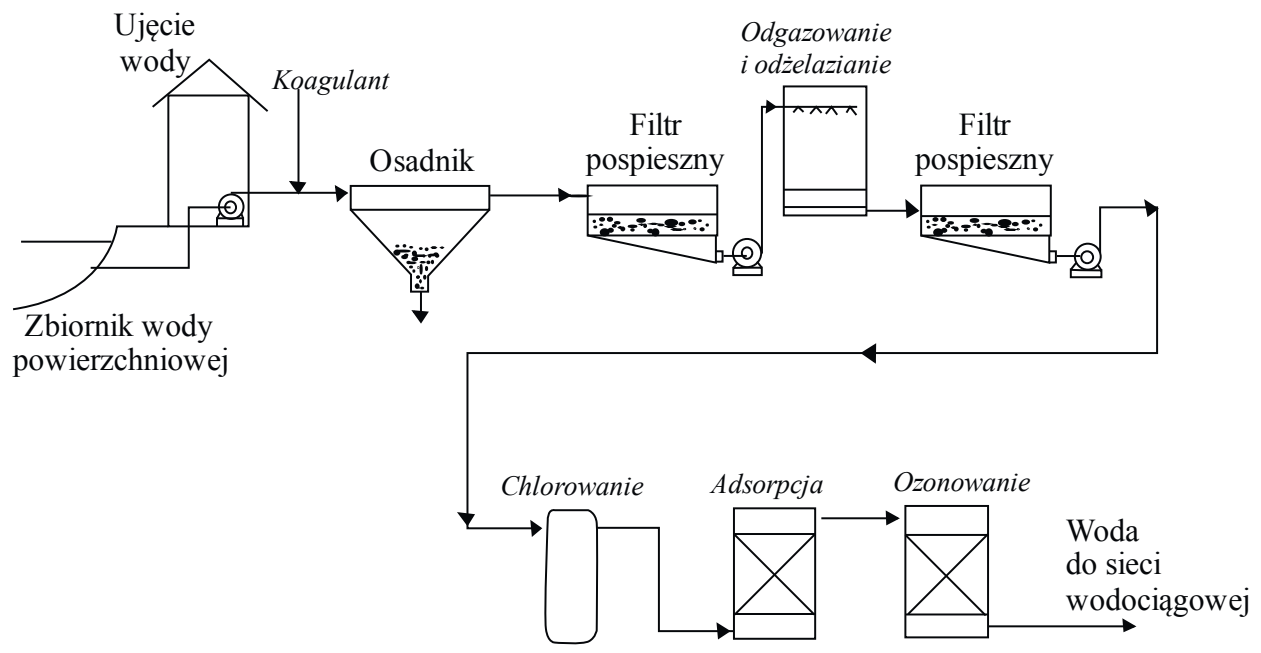

Rys. 9.1. Schemat ciągu technologicznego służącego do uzdatniania wody pitnej

Źródło: opracowanie własne na podstawie R. Zarzycki i in., Wprowadzenie do inżynierii i ochrony środowiska, t. 1: Ochrona środowiska naturalnego, Wydawnictwa NaukowoTechniczne, Warszawa 2007, s. 321 
Wybór metod stosowanych w uzdatnianiu wody do celów gospodarczych zależy od wymagań wynikających z jej przeznaczenia, określających jej właściwości i skład. W przypadku wód przemysłowych istotne są skład chemiczny oraz parametry fizyczne wody. Powinna być ona miękka (bez rozpuszczonych soli i gazów), mieć stałą temperaturę, a nie powinna zawierać zanieczyszczeń stałych pochodzenia organicznego i nieorganicznego.

W niektórych branżach (np. energetyce jądrowej, mikroelektronice, w przemyśle farmaceutycznym) niezbędne jest niekiedy bardzo głębokie oczyszczenie wody. Woda dla przemysłu spożywczego powinna odpowiadać podobnym kryteriom jak woda do picia, lecz czasami istnieje potrzeba spełnienia specjalnych kryteriów, jak w przypadku browarów (odpowiednia miękkość, czyli znacznie mniejsza ilość rozpuszczonych soli). Z kolei woda dla mleczarni nie powinna zawierać rozpuszczonego tlenu oraz zdecydowanie mniej bakterii, soli żelaza i manganu.

Zabiegi stosowane w uzdatnianiu wody mogą być realizowane z wykorzystaniem różnych metod. Najbardziej znane metody to: klarowanie, odbarwianie, odżelazianie, odmanganianie, dezodoryzacja, dezynfekcja, odgazowanie, zmiękczanie, odkrzemianie, odsalanie, demineralizacja, stabilizacja, dezaktywacja i fluorowanie. W praktyce na podstawie badań fizycznych, chemicznych i biologicznych dokonuje się odpowiedniego wyboru kilku metod, w pewnej określonej sekwencji, aby ostatecznie uzyskać wymagany efekt uzdatniania wody.

Metody mechaniczne w uzdatnianiu i odnowie wody służą usuwaniu zawiesin i odgazowaniu. Poniżej scharakteryzowano kilka wybranych metod mechanicznych.

Cedzenie polega na oddzieleniu od oczyszczanego strumienia wody lub ścieków cząstek ciał stałych o stosunkowo dużych rozmiarach. Woda zawierająca zanieczyszczenia tego typu jest przepuszczana najczęściej przez system krat lub sit, a następnie jest kierowana do osadników, gdzie dochodzi do oddzielenia drobnych zawiesin.

W procesie filtracji zawiesina jest przepuszczana przez odpowiednią przegrodę filtracyjną, która zatrzymuje cząstki ciał stałych, tworząc tzw. placek filtracyjny. Ciecz, przepływając przez przegrodę, tworzy tzw. filtrat. Stosuje się dwa podstawowe rodzaje filtrów: powolne i pospieszne (rys. 9.2). Wydajność filtrów pospiesznych jest znacznie większa niż powolnych, a można tę wydajność jeszcze zwiększyć, stosując ciśnieniowe filtry pospieszne. 


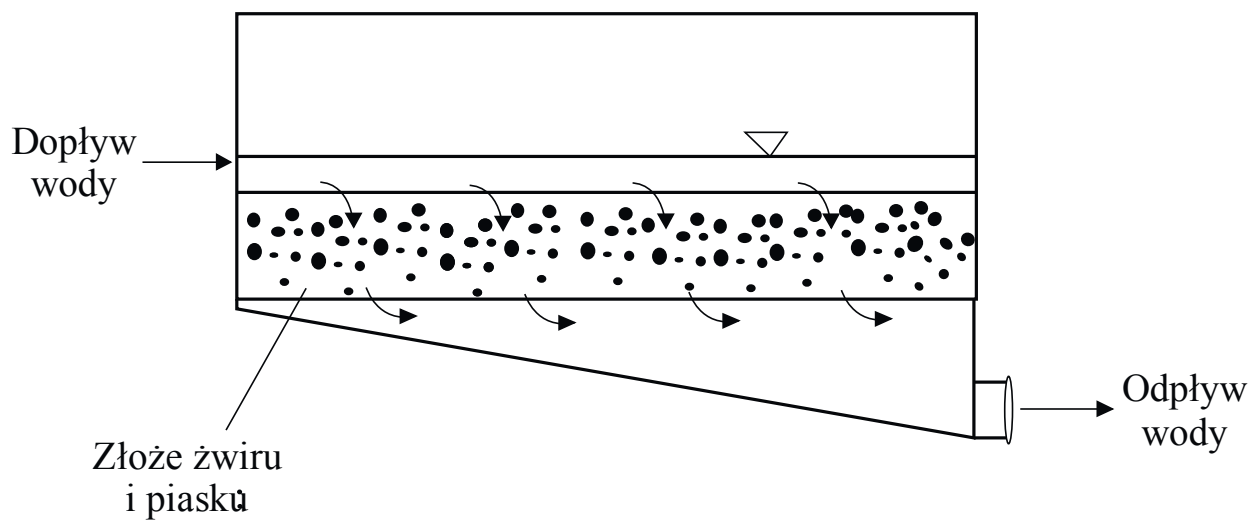

Rys. 9.2. Schemat działania filtra pospiesznego

Źródło: opracowanie własne na podstawie R. Zarzycki i in., Wprowadzenie do inżynierii i ochrony środowiska, t. 1: Ochrona środowiska naturalnego, Wydawnictwa Naukowo-Techniczne, Warszawa 2007, s. 274

Osadniki są zbiornikami, przez które powoli przepływa woda i w których osadzają się cięższe od wody cząstki ciał stałych. Oddzielenie osadów następuje na drodze sedymentacji, czyli samorzutnego opadania cząstek ciała stałego rozproszonego w cieczy i zachodzi pod wpływem siły grawitacji. Woda zawierająca zawiesiny przepływa przez poszczególne zbiorniki, a cząstki ciał stałych opadają na dno osadnika. Odpływ wody następuje pojedynczymi strugami przez poziome przelewy z grzebieniowymi wcięciami. W celu przyspieszenia procesu sedymentacji zawiesin do wody dodaje się koagulanty, powodujące aglomerację cząstek ciał stałych i przyspieszające ich opadanie. Rysunek 9.3 przedstawia schemat działania takiego osadnika.

Flotacja jest procesem odwrotnym do sedymentacji. Stosowana jest do usunięcia zanieczyszczeń tworzących z wodą trwałe układy dwufazowe, w których gęstość fazy rozproszonej jest mniejsza niż gęstość wody.

W uzdatnianiu i odnowie wody stosuje się także wiele metod fizycznych i chemicznych. Adsorbcja na węglu aktywnym jest procesem wykorzystywanym powszechnie do usuwania mikrozanieczyszczeń z wody i poprawy jej własności organoleptycznych i zdrowotnych. Pojawia się jako końcowy etap oczyszczania wody, służący głównie do usuwania związków chlorowcoorganicznych. Złoża węgla aktywnego pokrywają się często złożem biologicznym, co dodatkowo sprzyja usuwaniu zanieczyszczeń mikrobiologicznych. Koszty eksploatacji takich filtrów są 
stosunkowo wysokie, ale parametry tak oczyszczonej wody spełniają wszelkie wymagania jakościowe.

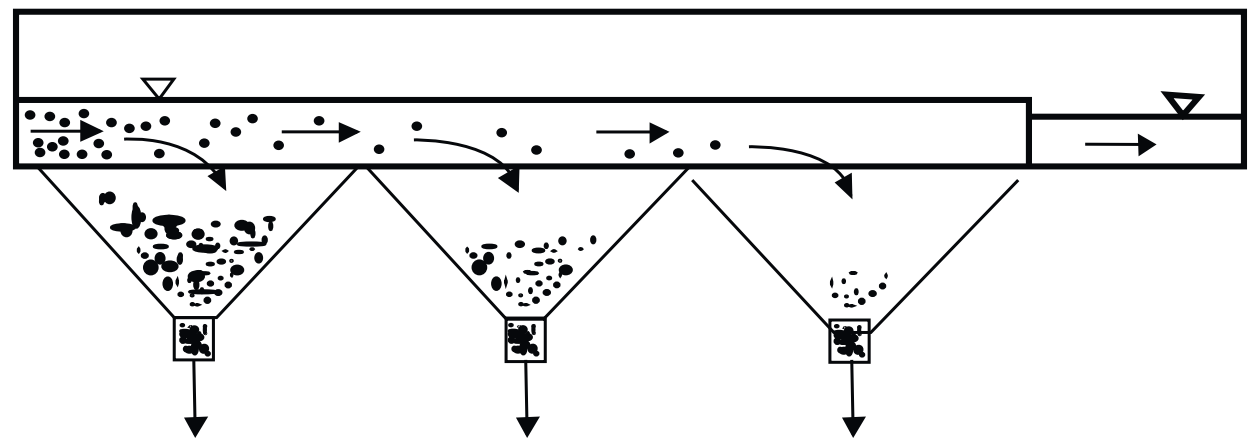

Rys. 9.3. Schemat działania osadnika wstępnego usuwającego zawiesiny metodą sedymentacji

Źródło: opracowanie własne na podstawie : R. Zarzycki i in., Wprowadzenie do inżynierii i ochrony środowiska, t. 1: Ochrona środowiska naturalnego, Wydawnictwa Naukowo-Techniczne, Warszawa 2007, s. 273

W procesie wymiany jonowej wykorzystuje się zjawisko wymiany jonów między tzw. jonitami osadzonymi na stałym podłożu a anionami lub kationami obecnymi w oczyszczanej wodzie. Jest ono przydatne przede wszystkim do demineralizacji (odsalania) wody i usuwania z niej zanieczyszczeń nieorganicznych, głównie w tych dziedzinach produkcji, w których obecność soli może zakłócać procesy technologiczne.

Chemiczne strącanie jest procesem znanym i stosowanym w technologii uzdatniania wody od wielu lat i pojawia się w wielu różnych układach technologicznych. W trakcie tego procesu związki występujące w postaci rozpuszczonej (substancje organiczne i fosfor) są wytrącane z wody w postaci związków nierozpuszczalnych. Obecne w wodzie drobne zawiesiny, zarówno te będące wynikiem pierwotnego zanieczyszczenia wody, jak i te pochodzące $z$ chemicznego strącenia, łączą się dzięki zjawisku koagulacji w większe agregaty (kłaczki osadu), które następnie są usuwane z wody. Koagulacja chemiczna sprowadza się do destabilizacji układu koloidalnego przez dodanie do wody reagentów i wytrącanie wodorotlenków metali. Na ich powierzchni adsorbują koloidy i zanieczyszczenia rozpuszczone w ściekach, stąd mogą one być oddzielone od fazy ciekłej wraz z osadem wodorotlenków. Wytrącone osady oddziela się od strumienia ścieków za pomocą procesów filtracji lub sedymentacji. 
Celem procesu utleniania jest destrukcja związków organicznych wywołujących barwę, smak i zapach wody, niszczenie organizmów żywych oraz destabilizacja koloidów. Do utleniania najczęściej stosuje się tlen zawarty w powietrzu, chlor, tlenek chloru IV, chloraminy, manganian VII potasu, ozon, promienie UV oraz coraz częściej metody zaawansowanego utleniania, oparte między innymi na reakcjach fotochemicznych. Przykładem utleniania jest dezynfekcja wód, która ma na celu usunięcie bakterii i mikroorganizmów. Dokonuje się tego przez: chlorowanie, ozonowanie, działanie nadtlenkiem wodoru, naświetlanie promieniami ultrafioletowymi. Do dezynfekcji stosowany jest najczęściej tlenek chloru IV $\left(\mathrm{ClO}_{2}\right)$ - skuteczny środek bakteriobójczy. Jego wadą jest to, że powoduje powstawanie ubocznych produktów utleniania - chlorynów i chloranów.

Odżelazianie i odmanganianie polega na napowietrzaniu wody zawierającej mangan i żelazo, w wyniku czego wytrącają się osady wodorotlenków tych metali, które następnie usuwane są w wyniku filtracji. Odgazowanie służy usunięciu gazów rozpuszczonych w wodzie (np. $\mathrm{CO}_{2}$, $\mathrm{NH}_{3}, \mathrm{SO}_{2}$ ). Natomiast desorpcja to proces wydzielania gazu z roztworu ciekłego, którego celem jest ulepszenie smaku i zapachu wody. Zmiękczenia wody dokonuje się przez wytrącanie związków wapnia i magnezu w procesie ogrzania wody lub z użyciem reagentów chemicznych. W ten sposób można usunąć twardość przemijającą. Do zmniejszenia twardości wody stosuje się także wymieniacze jonowe pracujące w cyklu sodowym. Skutecznym sposobem zabezpieczania kotłów przed kamieniem jest poprawianie wody zasilającej, które polega na dodawaniu do niej węglanu lub wodorotlenku sodu.

Destylacja pomaga w demineralizacji wody, choć jest procesem energochłonnym i przez to kosztownym. Tańszym sposobem jest stosowanie wielostopniowych wyparek. Demineralizację w odsalaniu wody morskiej można prowadzić również metodami elektrochemicznymi (np. elektrodializą lub elektroosmozą).

Obecnie bardzo przydatne $\mathrm{w}$ uzdatnianiu wody są procesy membranowe ciśnieniowe. Mikrofiltracja może być stosowana do klarowania wody, natomiast membrana ultrafiltracyjna - jako skuteczna bariera dla zawiesin i mikroorganizmów - do klarowania i dezynfekcji. Zmiękczanie wody i usuwanie mikrozanieczyszczeń można przeprowadzić, wykorzystując nanofiltrację. Odwrócona osmoza natomiast jest często stosowana do odsalania wód słonawych i słonych oraz do usuwania mikrozanieczyszczeń ze względu na wysoką skuteczność zatrzymywania jonów jednowartościowych i większości związków organicznych małocząsteczkowych. 


\section{Literatura}

Denczew S. (red.), Podstawy nowoczesnej eksploatacji układów wodociągowych i kanalizacyjnych, Wydawnictwo Arkady, Warszawa 2003.

Gromiec M., Słowik N. (red.), Zastosowanie nowych technologii w sektorze ochrony środowiska, NFOśiGW, Warszawa 2006.

Heidrich Z., Gospodarka wodno-ściekowa: przepisy, normy, technologie, metody postępowania, Verlag Dashöfer cop., Warszawa 2002.

Kalenik M., Zaopatrzenie w wodę $i$ odprowadzanie ścieków, Wydawnictwo SGGW, Warszawa 2009.

Knapik K., Bajer J., Wodociągi, Wydawnictwo Politechniki Krakowskiej, Kraków 2010.

Kowal A.L., Świderska-Bróż M., Oczyszczanie wody: podstawy teoretyczne i technologiczne, procesy i urządzenia, PWN, Warszawa 2009.

Kowal A.L., Świderska-Bróż M., Oczyszczanie wody, PWN, Warszawa-Wrocław 2003.

Łyp B., Infrastruktura wodno-ściekowa w planowaniu miast, Wydawnictwo Komunikacji i Łączności, Warszawa 2008.

Nawirska-Olszańska A., Procesy membranowe $w$ procesie uzdatniania wody, „Przemysł Spożywczy”, z. 6/2015.

Oczyszczanie wody - nowe trendy, Materiały VI Konferencji „Woda - ścieki - odpady w środowisku", Zielona Góra 2003.

Olszta W., Podstawy inżynierii wodnej środowiska, Wydawnictwo Politechniki Lubelskiej, Lublin 2004.

Szpindor A., Zaopatrzenie w wodę i kanalizacja wsi, Wydawnictwo Arkady, Warszawa 1998.

Rozporządzenie Ministra Środowiska z dnia 20 kwietnia 2007 r. w sprawie warunków technicznych, jakim powinny odpowiadać budowle hydrotechniczne i ich usytuowanie (Dz.U. z 2007 r. Nr 86, poz. 579).

Ustawa o zbiorowym zaopatrzeniu w wodę i zbiorowym oczyszczaniu ścieków z dnia 7 czerwca 2001 r. (Dz.U. z dnia 27 stycznia 2015, poz. 139).

Zarzycki R., Imbierowicz M., Stelmachowski M., Wprowadzenie do inżynierii $i$ ochrony środowiska, t. 1: Ochrona środowiska naturalnego, Wydawnictwa Naukowo-Techniczne, Warszawa 2007. 


\section{Rozdział 10}

\section{Systemy wodociągowe i kanalizacyjne}

\subsection{Systemy wodociągowe}

Systemy zaopatrzenia w wodę stanowią istotny element systemu wodno-gospodarczego na poziomie kraju i regionu. Są zespołem współpracujących ze sobą obiektów budowlanych i urządzeń. Systemy te są efektem inżynierskich działań obejmujących fazę projektowania, budowy i eksploatacji. Zwyczajowo zamiennie używa się terminów: systemy wodociągowe, sieci wodociągowe, układy wodociągowe czy wodociągi, jednak istnieją między tymi pojęciami pewne różnice. Omawianie zagadnień związanych z systemami wodociągowymi należy więc rozpocząć od podania podstawowych definicji.

Urządzeniami wodociągowymi są ujęcia wód powierzchniowych i podziemnych, studnie publiczne, urządzenia służące do magazynowania i uzdatniania wód, sieci wodociągowe, a także urządzenia regulujące ciśnienie wody. Wodociąg jest więc układem połączonych przewodów, armatury i urządzeń, zbiorem elementów o strukturze liniowej wraz z obiektami budowlanymi i urządzeniami, połączonych pierścieniowo lub usytuowanych promieniście. Zbiorniki wodociągowe i pompownie sieciowe są traktowane najczęściej jako składniki dodatkowe, wspomagające lub usprawniające pracę sieci. Podstawowym zadaniem wodociągu jest dostarczenie odbiorcom wody w sposób ciągły, w wymaganych przez nich ilościach i o ciśnieniu zapewniającym pełny komfort poboru, a także spełniającej w miejscu poboru wszystkie normy jakościowe.

Sieć wodociągową stanowią przewody wodociągowe (wraz z uzbrojeniem i urządzeniami) znajdujące się poza budynkami odbiorców i zaopatrujące ludność lub zakłady produkcyjne w wodę, a będące w posiadaniu przedsiębiorstwa wodociągowo-kanalizacyjnego. Przyłącze wodociągowe to odcinek przewodu łączącego sieć wodociągową z wewnętrzną instalacją wodociągową w nieruchomości odbiorcy usług wraz z zaworem za wodomierzem głównym.

Należy jeszcze wyjaśnić, czym jest przedsiębiorstwo wodociągowo-kanalizacyjne. Może być to przedsiębiorca (w rozumieniu przepisów 
o swobodzie działalności gospodarczej), jeżeli prowadzi działalność gospodarczą w zakresie zbiorowego zaopatrzenia w wodę lub zbiorowego odprowadzania ścieków, jak również mogą być to gminne jednostki organizacyjne nieposiadające osobowości prawnej, prowadzące tego rodzaju działalność.

W najprostszej klasyfikacji instalacje wodociągowe dzielimy na: wewnętrzne, prowadzone wewnątrz budynków oraz instalacje wodociągowe zewnętrzne, prowadzone na zewnątrz budynków, czyli tzw. Sieci wodociągowe. Oprócz tego wodociągi możemy sklasyfikować według lokalizacji zbiornika na wodociągi ze zbiornikiem początkowym, końcowym lub centralnym, natomiast według liczby zasilanych jednostek osadniczych na pojedyncze i grupowe. Istotny jest również podział ze względu na ilość zastosowanych stref (rys. 10.1).
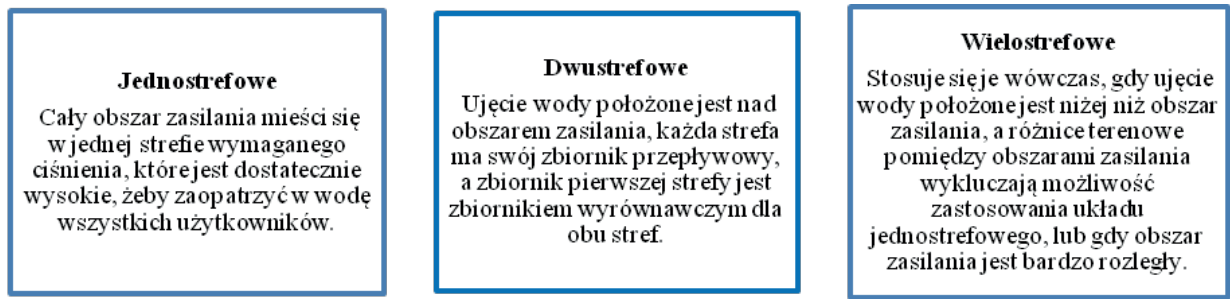

Rys. 10.1. Podział układów wodociągowych ze względu na ilość zastosowanych stref zasilania

Źródło: opracowanie własne na podstawie literatury przedmiotu

Sposób prezentowania schematów układów wodociągowych w literaturze przedmiotu jest bardzo różny. W zależności od warunków pracy wodociągu określa się jego charakter i przeznaczenie, a następnie dobiera poszczególne urządzenia i obiekty. Duże znaczenie w tym względzie mają warunki naturalne, czyli ukształtowanie terenu, usytuowanie wysokościowego ujęcia wody oraz jego oddalenie od rejonu zaopatrzenia w wodę. Najprostszy schemat układu wodociągowego obejmuje: obiekty standardowe, czyli ujęcie wody, studnię zbiorczą, pompownię oraz sieć rozdzielczą, a także stację uzdatniania wody oraz zbiornik górny końcowy. Transport wody odbywa się przewodem tłocznym tranzytowym od ujęcia wody do zbiornika górnego końcowego (rys. 10.2). Nie ma potrzeby włączenia do układu wodociągowego stacji uzdatniania, jeśli woda jest pobierana $z$ ujęcia wody podziemnej lub ze źródeł naturalnych i charakteryzuje się wysokim stopniem czystości. W rejonach 
podgórskich, gdzie ujęcie wody położone jest nad obszarem zasilania, dodatkowo nie ma konieczności włączenia do układu także pompowni. Woda z ujęcia spływa bowiem grawitacyjnie do zbiornika wyrównawczego, a z niego również grawitacyjnie przewodem tranzytowym do sieci rozdzielczej obszaru zasilania.

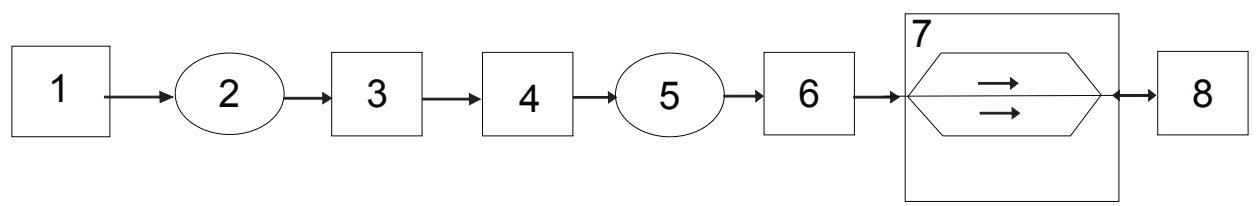

Rys. 10.2. Schemat przykładowego pełnego układu wodociągowego

Oznaczenia: 1 - ujęcie wody powierzchniowej, 2 - studnia zbiorcza, 3 - pompownia I stopnia, 4 - stacja uzdatniania wody, 5 -zbiornik terenowy dolny, 6 - pompownia II stopnia, 7 - obszar zasilania z siecią rozdzielczą, 8 - zbiornik górny końcowy

Źródło: opracowanie własne na podstawie Denczew S. (red.), Podstawy nowoczesnej eksploatacji układów wodociągowych i kanalizacyjnych, Wydawnictwo Arkady,

Warszawa 2003, s. 19

W przypadku układów wodociągowych rozróżnia się następujące rodzaje przewodów: tranzytowy, magistralny, rozdzielczy i przyłącze domowe. Przewód tranzytowy (nazywany też przesyłowym) to przewód wodociągowy bez odgałęzień, przeznaczony do transportu wody na znaczne odległości, łączący najczęściej źródło wody ze zbiornikiem początkowym lub magistralą wodociągową. Może być grawitacyjny lub tłoczny. Z kolei przewód magistralny (tzw. magistrala wodociągowa) to przewód wodociągowy doprowadzający wodę ze stacji wodociągowej do przewodów rozdzielczych. Przewód rozdzielczy to przewód wodociągowy doprowadzający wodę z przewodu magistralnego do podłączeń domowych i innych punktów czerpalnych. Natomiast podłączenie wodociągowe (przyłącze domowe) jest przewodem wodociągowym z zamontowanym zestawem wodomierzowym, który łączy sieć wodociągową rozdzielczą (uliczną) z instalacją wewnętrzną obiektu zasilanego w wodę.

Ze względu na różne warunki pracy przewodów sieci wodociągowych podczas transportu wody rozróżnia się przewody:

- ciśnieniowe, w których przepływ wody następuje wskutek ciśnienia wytworzonego przez pompę;

- grawitacyjne ciśnieniowe, w których przepływ wody odbywa się pod ciśnieniem statycznym wody z wyżej położonego źródła; 
- grawitacyjne bezciśnieniowe, w których przepływ wody odbywa się ze swobodnym zwierciadłem pod działaniem siły ciężkości.

W celu zapewnienia prawidłowej eksploatacji przewodów sieci wodociągowych konieczne jest utrzymywanie tych przewodów wraz z uzbrojeniem i wyposażeniem w stanie pełnej sprawności technicznej. Należy przeprowadzać systematyczne kontrole i prace konserwacyjne, niezwłocznie usuwać powstałe uszkodzenia i awarie, w trybie ciągłym monitorować pracę układu wodociągowego pod względem ilości i jakości dostarczanej wody oraz wystarczającego ciśnienia, a oprócz tego przeprowadzać planowo remonty.

Uzbrojenie, czyli tzw. armatura sieci wodociągowej umożliwia korzystanie z niej zgodnie z przeznaczeniem. Ponadto ułatwia obsługę, kontrolę i eksploatację sieci. Wśród podstawowego uzbrojenia sieci wodociągowej znajdują się urządzenia:

- regulujące przepływ wody, czyli zasuwy, klapy zwrotne, przepustnice i zawory sterujące;

- czerpalne, jak np. hydranty i zdroje uliczne;

- zabezpieczające, o charakterze ochronnym - odpowietrzniki, wydłużki kompensacyjne, kosze ssawne, zawory;

- pomiarowe - np. wodomierze i manometry lub inne urządzenia do pomiaru ciśnienia.

Tabela 10.1. Urządzenia wodociągowe w Polsce w latach 2005, 2010, 2013-2014

\begin{tabular}{|c|c|c|c|c|c|c|c|c|}
\hline \multirow{4}{*}{ Rok } & \multirow{2}{*}{\multicolumn{3}{|c|}{$\begin{array}{l}\text { Sieć wodociągowa } \\
\text { rozdzielcza }\end{array}$}} & \multirow{2}{*}{\multicolumn{3}{|c|}{$\begin{array}{c}\text { Połączenia prowadzące do } \\
\text { budynków mieszkalnych }\end{array}$}} & \multirow{2}{*}{\multicolumn{2}{|c|}{ Zdroje uliczne }} \\
\hline & & & & & & & & \\
\hline & \multicolumn{3}{|c|}{ w km } & \multicolumn{5}{|c|}{ w szt. } \\
\hline & ogółem & miasta & wieś & ogółem & miasta & wieś & ogółem & $\begin{array}{c}\text { w tym } \\
\text { wieś }\end{array}$ \\
\hline 2005 & 245601 & 54872 & 190729 & 4509230 & 1757120 & 2752110 & 6547 & 3143 \\
\hline 2010 & 272888 & 61003 & 211885 & 4947378 & 1910710 & 3036668 & 5442 & 2407 \\
\hline 2013 & 287651 & 64187 & 223465 & 5272977 & 2024503 & 3248474 & 4643 & 1950 \\
\hline 2014 & 292456 & 65628 & 226828 & 5372455 & 2056155 & 3316300 & 4584 & 1938 \\
\hline
\end{tabular}

Źródło: opracowanie własne na podstawie danych GUS'.

1 http://stat.gov.pl/obszary-tematyczne/infrastruktura-komunalna-nieruchomosci/ nieruchomosci-budynki-infrastruktura-komunalna/infrastruktura-komunalna-w-2014-r-,3,12.html. (data dostępu: 23 listopada 2015 roku) 
Zawór odpowietrzający (odpowietrznik) służy do usuwania powietrza zwykle z układów hydraulicznych. Zawór ten umożliwia samoczynne napowietrzanie i odpowietrzanie instalacji centralnego ogrzewania. Wodomierz to potoczna nazwa wskaźnika lub przyrządu pomiarowego będącego połączeniem przepływomierza z licznikiem.

\subsection{Systemy kanalizacyjne}

Urządzenia kanalizacyjne to zespół urządzeń przeznaczonych do ujęcia, oczyszczania oraz odprowadzania wód deszczowych oraz ścieków komunalnych i przemysłowych. Obejmują sieci kanalizacyjne, wyloty urządzeń kanalizacyjnych służących do wprowadzania ścieków do wód lub do ziemi, urządzenia podczyszczające i oczyszczające ścieki oraz przepompownie ścieków. W skład podstawowego układu kanalizacyjnego wchodzą następujące elementy:

- instalacje wewnętrzne w budynkach;

- przewody zewnętrzne na terenie działek budowlanych (tzw. przykanaliki), osiedli mieszkaniowych lub zakładów przemysłowych;

- sieci kanałów ulicznych;

- oczyszczalnie ścieków;

- przewody i urządzenia służące do odprowadzania oczyszczonych ścieków do odbiornika.

Sieć kanalizacyjną stanowią przewody kanalizacyjne wraz z uzbrojeniem i urządzeniami, którymi odprowadzane są ścieki, będące w posiadaniu przedsiębiorstwa wodociągowo-kanalizacyjnego. Urządzenie pomiarowe to przyrząd pomiarowy mierzący ilość odprowadzanych ścieków, który znajduje się na przyłączu kanalizacyjnym. Z kolei przyłączem kanalizacyjnym nazywamy odcinek przewodu łączącego wewnętrzną instalację kanalizacyjną w nieruchomości odbiorcy usług z siecią kanalizacyjną (za pierwszą studzienką, licząc od strony budynku, a w razie jej braku do granicy nieruchomości gruntowej).

Transport ścieków do oczyszczalni, a po oczyszczeniu do odbiornika odbywa się za pomocą kanałów zainstalowanych na terenie działek budowlanych i osiedli mieszkaniowych oraz sieci kanałów ulicznych. Do kanałów kanalizacyjnych mogą być odprowadzane następujące rodzaje 
odpływów: ścieki bytowo-gospodarcze, przemysłowe, opadowe i roztopowe, a także wody infiltracyjne i przypadkowe.

Według kryterium rodzaju zadań, które ma spełniać układ kanalizacyjny, wyróżniamy dwa podstawowe rodzaje kanalizacji: pełną i częściową. Pełna służy do odprowadzania ścieków bytowo-gospodarczych, przemysłowych, opadowych i roztopowych. Natomiast częściową odprowadza się przede wszystkim ścieki bytowo-gospodarcze i przemysłowe, a czasami tylko ścieki opadowe i roztopowe oraz wody gruntowe z systemów odwadniających (uzbrojone w sieć kanalizacji deszczowej).

Układy kanalizacyjne w miastach i na obszarach niezurbanizowanych można podzielić na konwencjonalne (grawitacyjne) oraz niekonwencjonalne. W zależności od systemu sieci konwencjonalnej kanalizacja pełna może być wykorzystana do odprowadzania wszystkich ścieków jako kanalizacja ogólnospławna, rozdzielcza lub półrozdzielcza. Kanalizacja ogólnospławna, choć jest przestarzałym układem, nadal jest najtańszym sposobem usuwania ścieków. Stosuje się ją głównie wówczas, gdy wszystkie rodzaje ścieków na terenie objętym jej zasięgiem transportuje się w jedną sieć, a następnie są one razem oczyszczane w miejskiej oczyszczalni ścieków o dużej przepustowości.

W kanalizacji rozdzielczej ścieki są spławiane dwoma oddzielnymi sieciami. Jedna z nich, która jest układana głębiej, transportuje ścieki bytowo-gospodarcze i przemysłowe. Druga sieć, znajdująca się znacznie płycej w stosunku do powierzchni terenu, transportuje ścieki opadowe. Ten rodzaj kanalizacji stosuje się, gdy:

- kanalizowany obszar jest stosunkowo mały;

- teren oraz otoczenie budynków i ulic są w niewielkim stopniu zabudowane i zagospodarowane;

- występuje ukształtowanie wysokościowe terenu o ciągłych spadkach;

- występuje duża liczba odbiorników ścieków opadowych.

Kanalizacja półrozdzielcza spotykana jest najczęściej w niewielkich miastach. Ścieki bytowo-gospodarcze i przemysłowe oraz ścieki opadowe są odprowadzane za pomocą dwóch rodzajów sieci, współdziałających ze sobą. Jest stosunkowo kosztowna, ponieważ istnieje konieczność 
budowy dodatkowych urządzeń do przejęcia zanieczyszczonych wód opadowych przez sieć ogólną.

Przed dokonaniem wyboru rodzaju kanalizacji konwencjonalnej na danym obszarze można wziąć pod uwagę wiele kryteriów, takich jak na przykład zasięg systemu kanalizacyjnego, standardy usług kanalizacyjnych i ochrony środowiska, ukształtowanie układu transportu ścieków, lokalizacja oczyszczalni ścieków, rozmieszczenie źródeł ścieków oraz prognoza ilości ścieków i ich zanieczyszczenia. Ocena wariantów rozwiązań powinna uwzględniać także kryteria użytkowe i ekonomiczne, a w szczególności: energochłonność, niezawodność funkcjonowania, procochłonność, koszty eksploatacji oraz elastyczność realizowanych rozwiązań, uwzględniających potencjalne zmiany zagospodarowania terenu. Odprowadzanie ścieków kanałami konwencjonalnymi z wykorzystaniem przede wszystkim siły ciężkości (dzięki pochyleniu dna kanału) jest nadal stosunkowo tanim i bezpiecznym pod względem sanitarnym sposobem transportu ścieków. Pompownie ścieków i przewody pracujące pod ciśnieniem stosuje się w tej metodzie tylko w niektórych przypadkach, ze względu na ukształtowanie terenu i ze względów technicznych, w tym możliwości zagłębiania kanałów.

Rozwiązaniami alternatywnymi wobec kanalizacji grawitacyjnej z kanałami częściowo wypełnionymi ściekami są układy kanalizacyjne niekonwencjonalne. Ten typ kanalizacji polega na mechanicznym wymuszaniu w sieci różnicy ciśnień, dzięki której następuje przepływ ścieków jedynie bytowo-gospodarczych i przemysłowych. Główny podział układów niekonwencjonalnych przedstawia się następująco:

- ciśnieniowe - polegają na wymuszaniu przepływu ścieków w sieci przewodów ciśnieniowych za pomocą pomp (rys. 10.3);

- podciśnieniowe - zasada ich działania polega na wymuszaniu przepływu ścieków w przewodach wskutek wytworzenia w sieci odpowiedniego podciśnienia.

System kanalizacji ciśnieniowej składa się z grawitacyjnego odpływu ścieków z budynku, urządzenia zbiornikowo-tłocznego, ciśnieniowego przykanalika (przyłącza) oraz części grawitacyjnej, którą tworzą studzienka rewizyjna i kanał odpływowy (rys. 10.3). Przewody zbiorcze kanalizacji ciśnieniowej mogą tworzyć sieć pierścieniową lub rozgałęzioną. 


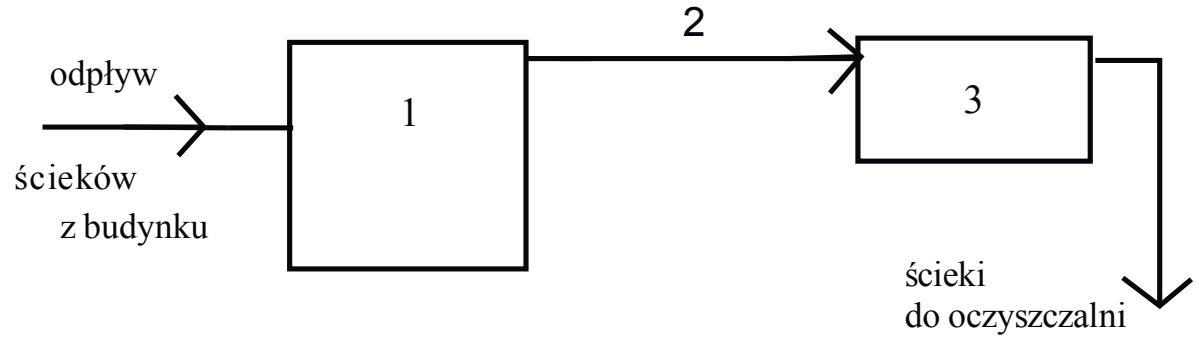

Rys. 10.3. Schemat przykładowego systemu kanalizacji ciśnieniowej

Oznaczenia: 1 - urządzenie zbiornikowo-tłoczne z pompą ściekową, 2 - przewody ciśnieniowe, 3 - studzienka przed oczyszczalnią ścieków

Źródło: opracowanie własne na podstawie Denczew S. (red.), Podstawy nowoczesnej eksploatacji układów wodociągowych i kanalizacyjnych, Wydawnictwo Arkady, Warszawa 2003, s. 83

Niekonwencjonalne układy stosuje się w przypadku braku naturalnych spadków terenu, gdy występują wysoki poziom wód gruntowych, niekorzystne warunki gruntowe, okresowo pojawiający się odpływ ścieków oraz niewielka gęstość zaludnienia.

Można wskazać wiele zalet tych systemów w porównaniu z konwencjonalnymi. Po pierwsze, istnieje możliwość układania kanałów równolegle do powierzchni terenu, na głębokościach równych lub nawet mniejszych od głębokości układania przewodów wodociągowych. Systemy te spełniają wymagania sanitarne w większym stopniu ze względu na mniejsze prawdopodobieństwo skażenia ściekami wód gruntowych. Z systemów niekonwencjonalnych powstaje mniejsza ilość ścieków dopływających do oczyszczalni dzięki eliminacji wód infiltracyjnych i przypadkowych. Poza tym charakteryzują się krótszym czasem realizacji inwestycji kanalizacyjnych.

Systemy niekonwencjonalne mają także wady, albowiem obciążone są znacznym zużyciem energii elektrycznej koniecznej do napędu pomp. Istnieje duże prawdopodobieństwo wystąpienia awarii elementów mechanicznych, a w kanalizacji ciśnieniowej może dojść do pęknięcia kanału grożącego skażeniem gruntu.

Według danych GUS² w minionym dziesięcioleciu sieć kanalizacyjna w Polsce znacznie się wydłużyła i wzrosła liczba nowych przyłączy

2 http://stat.gov.pl/obszary-tematyczne/infrastruktura-komunalna-nieruchomosci/ nieruchomosci-budynki-infrastruktura-komunalna/infrastruktura-komunalna-w-2014-r-,3,12.html. 
kanalizacyjnych. Na terenach wiejskich nastąpił ponad dwukrotny wzrost tych wskaźników w 2014 roku w porównaniu do 2005 roku. W 2014 roku na obszarach wiejskich usytuowane było prawie $57 \%$ długości sieci kanalizacyjnej i około 44\% liczby przyłączy (tab. 10.2).

Tabela 10.2. Urządzenia kanalizacyjne w Polsce w latach 2005, 2010, 2013-2014

\begin{tabular}{|c|c|c|c|c|c|c|}
\hline \multirow{2}{*}{ Rok } & \multicolumn{3}{|c|}{$\begin{array}{c}\text { Sieć ogólnospławna i na ścieki } \\
\text { gospodarcze }\end{array}$} & \multicolumn{3}{c|}{$\begin{array}{c}\text { Przyłącza prowadzące } \\
\text { do budynków mieszkalnych }\end{array}$} \\
\cline { 2 - 7 } & \multicolumn{3}{|c|}{ w km } & \multicolumn{3}{c|}{ w szt. } \\
\cline { 2 - 7 } & ogółem & miasta & wieś & ogółem & miasta & wieś \\
\hline 2005 & 80131 & 43310 & 36821 & 1754512 & 1156517 & 597995 \\
2010 & 107509 & 51943 & 55566 & 2318987 & 1412713 & 906274 \\
2013 & 132916 & 57626 & 75290 & 2763988 & 1581827 & 1182161 \\
2014 & 142876 & 61509 & 81367 & 2912618 & 1633583 & 1279035 \\
\hline
\end{tabular}

Źródło: opracowanie własne na podstawie danych GUS 3 .

Według Dyrektywy ściekowej 91/271/EWG systemy kanalizacji zbiorczej ścieków powinny spełniać pewne określone wymagania. Odnośnie ścieków komunalnych wymagania są następujące: projektowanie, budowa i utrzymanie tych systemów powinny być realizowane zgodnie z najlepszą wiedzą techniczną, bez powodowania nadmiernych kosztów, szczególnie w odniesieniu do objętości i charakteru ścieków, zapobiegania przeciekom, ograniczenia zanieczyszczenia wód będących odbiornikami ścieków powodowanego przez przelewy wód burzowych.

Główne wymagania wobec systemów kanalizacji dla ścieków przemysłowych dotyczą konieczności poddania tych ścieków wstępnemu oczyszczaniu w celu:

- ochrony zdrowia pracowników zatrudnionych przy eksploatacji systemów kanalizacji zbiorczej i oczyszczalni;

- zapewnienia, że systemy kanalizacji zbiorczej, oczyszczalnie ścieków i urządzenia towarzyszące nie zostaną uszkodzone;

3 http://stat.gov.pl/obszary-tematyczne/infrastruktura-komunalna-nieruchomosci/ nieruchomosci-budynki-infrastruktura-komunalna/infrastruktura-komunalna-w-2014-r-,3,12.html. (data dostępu: 25 listopada 2015 roku) 
- zapewnienia, że działanie oczyszczalni ścieków komunalnych i obróbka osadu nie będą utrudnione;

- zapewnienia, że zrzuty z oczyszczalni nie wpłyną niekorzystnie na środowisko, a wodom będącym odbiornikiem ścieków nie utrudnią spełnienia ich roli w zgodzie z innymi dyrektywami Wspólnoty;

- zapewnienia, że osad może być usuwany w sposób bezpieczny i właściwy ze względu na ochronę środowiska.

Dla funkcjonowania zbiorczego systemu kanalizacyjnego niezwykle istotny jest sposób wykonywania napraw i renowacji kanalizacji ściekowej. W procedurach remontowych wybór stosowanej w danym przypadku technologii powinien być każdorazowo poprzedzony dokładną analizą zgromadzonych danych eksploatacyjnych i wymagań funkcjonalnych. W razie konieczności wykonania renowacji na obszarze zurbanizowanym należy stosować technologie bezwykopowe, które są korzystniejsze od tradycyjnych (w wykopach otwartych) ze względu na uwarunkowania ekonomiczne i organizacyjne. Różnorodność technik bezwykopowych, przedstawiona $w$ rozdziale piątym niniejszego podręcznika, umożliwia przywrócenie pełnej sprawności systemowi kanalizacyjnemu niezależnie od rodzaju uszkodzenia, które wymaga naprawy.

Rozważania na temat zaopatrzenia w wodę oraz odprowadzenia ścieków warto zakończyć analizą statystyczną danych o eksploatacji wodociągów i kanalizacji. Przede wszystkim należy zaznaczyć, że w Polsce w ostatnich kilku latach nastąpił znaczny wzrost inwestycji w obszarze infrastruktury techniczno-sanitarnej. Według danych GUS w latach 2007-2014 długość sieci wodociągowej zwiększyła się o 35,4 tys. km, w tym ponad 26,5 tys. $\mathrm{km}$ sieci wybudowano na obszarach wiejskich. Liczba przyłączy wodociągowych wzrosła ogółem o ponad 749 tys. (ok. 486 tys. na obszarach wiejskich). W tym samym okresie długość sieci kanalizacyjnej zwiększyła się o około 53,4 tys. km, w tym prawie 32 tys. km sieci powstało na obszarach wiejskich. Zainstalowano ponad 946 tys. nowych przyłączy kanalizacyjnych, w tym ponad 562 tys. na obszarach wiejskich. Według stanu na dzień 31.12.2014 roku 96,4\% ludności Polski zamieszkałej w miastach korzystało z sieci wodociągowej i 87,9\% - z sieci kanalizacyjnej. W przypadku ludności zamieszkałej na obszarach wiejskich odsetek ten kształtował się na poziomie odpowiednio: $84,3 \%$ oraz $37,4 \%$ i w stosunku do poprzedniego roku wykazuje tendencję wzrostową. 
Z danych GUS wynika, że na dzień 31.12.2014 roku pobrano łącznie ze wszystkich ujęć $1988,1 \mathrm{hm}^{3}$ wody, w tym z ujęć powierzchniowych $572,2 \mathrm{hm}^{3}$. W ciągu całego 2014 roku zużyto razem $1537 \mathrm{hm}^{3}$ wody z wodociągów. Przeciętne zużycie wody przez gospodarstwa domowe wyniosło $31,1 \mathrm{~m}^{3}$ na 1 mieszkańca (w miastach - ok. $34 \mathrm{~m}^{3}$, a na obszarach wiejskich - 26,8 $\mathrm{m}^{3}$ ). W porównaniu z 2013 rokiem średnie zużycie wody przez gospodarstwa domowe w skali kraju spadło o $0,2 \mathrm{~m}^{3}$.

W 2014 roku odprowadzono razem 1238,1 hm³ ścieków, w tym z gospodarstw domowych około $906 \mathrm{hm}^{3}$, z czego około $88 \%$ stanowiły ścieki odprowadzone z terenów miejskich. W porównaniu z 2013 rokiem ilość ścieków odprowadzonych siecią kanalizacyjną z gospodarstw domowych w miastach spadła o około $7,6 \mathrm{hm}^{3}$, natomiast na terenach wiejskich wzrosła o $1 \mathrm{hm}^{3}$. Od kilku lat obserwowany jest systematyczny spadek liczby zbiorników bezodpływowych, w związku z tym spada także ilość nieczystości ciekłych odbieranych od właścicieli tych zbiorników i dostarczanych do oczyszczalni ścieków lub stacji zlewnych (tab. 10.3).

Tabela 10.3. Gospodarka wodociągowo-kanalizacyjna w Polsce w latach 2005, 2010, 2013-2014

\begin{tabular}{|l|r|r|r|r|}
\hline \multicolumn{1}{|c|}{ Wyszczególnienie } & 2005 & 2010 & 2013 & 2014 \\
\hline $\begin{array}{l}\text { Sieć wodociągowa w tys. km (stan w dniu 31.12): } \\
\text { rozdzielcza }\end{array}$ & 245,6 & 272,9 & 287,7 & 292,5 \\
przesyłowa (magistralna) & 28,7 & 16,8 & 17,4 & 17,4 \\
\hline $\begin{array}{l}\text { Sieć kanalizacyjna (rozdzielcza i kolektory) } \\
\text { w tys. km (stan w dniu 31.12): }\end{array}$ & 80,1 & 107,6 & 132,9 & 142,9 \\
\hline $\begin{array}{l}\text { Zużycie wody z wodociągów (w ciągu roku) } \\
\text { W hm } \\
\text { W gospodarstwach domowych }\end{array}$ & 1219,4 & 1197,9 & 1191,1 & 1196,0 \\
miasta: na 1 mieszkańca & 37,2 & 35,2 & 34,0 & 33,9 \\
\hline $\begin{array}{l}\text { Ścieki odprowadzone siecią kanalizacyjną } \\
\text { (w ciągu roku) w hm }\end{array}$ & 1273,6 & 1297,8 & 1246,6 & 1238,1 \\
\hline $\begin{array}{l}\text { Nieczystości ciekłe wywiezione (gromadzone } \\
\text { przejściowo w zbiornikach bezodpływowych) } \\
\text { w hm }\end{array}$ & 18,2 & 24,7 & 23,1 & 22,9 \\
\hline
\end{tabular}

Źródło: opracowanie własne na podstawie danych GUS4.

4 http://stat.gov.pl/obszary-tematyczne/infrastruktura-komunalna-nieruchomosci/ nieruchomosci-budynki-infrastruktura-komunalna/infrastruktura-komunalna-w-2014-r-,3,12.html. (data dostępu: 27 listopada 2015 roku) 


\section{Literatura}

Denczew S. (red.), Podstawy nowoczesnej eksploatacji układów wodociągowych i kanalizacyjnych, Wydawnictwo Arkady, Warszawa 2003.

Dyrektywa Rady 91/271/EWG z dnia 21 maja 1991 r. dotycząca oczyszczania ścieków komunalnych (Dz.Urz. UE L 135/40).

Gromiec M., Słowik N. (red.), Zastosowanie nowych technologii w sektorze ochrony środowiska, NFOŚiGW, Warszawa 2006.

Heidrich Z., Gospodarka wodno-ściekowa: przepisy, normy, technologie, metody postępowania, Verlag Dashöfer, cop., Warszawa 2002.

Infrastruktura komunalna w 2014 r., GUS, Warszawa 2015.

Kalenik M., Zaopatrzenie w wodę $i$ odprowadzanie ścieków, Wydawnictwo SGGW, Warszawa 2009.

Kujawski W., Bezwykopowa renowacja kanalizacji ściekowej jako element utrzymania zbiorczego systemu kanalizacyjnego PEWIK Gdynia, [w:] Kompleksowa gospodarka wodno-ściekowa w aspekcie norm unijnych, Materiały seminaryjne Nr 50(2006), Instytut Technologiczno-Przyrodniczy, Falenty 2006.

Łyp B., Infrastruktura wodno-ściekowa w planowaniu miast, Wydawnictwa Komunikacji i Łączności, Warszawa 2008.

Ustawa o zbiorowym zaopatrzeniu w wodę i zbiorowym oczyszczaniu ścieków z dnia 7 czerwca 2001 r. (Dz.U. z dnia 27 stycznia 2015 r., poz. 139).

Zarzycki R., Imbierowicz M., Stelmachowski M., Wprowadzenie do inżynierii i ochrony środowiska, t. 1: Ochrona środowiska naturalnego, Wydawnictwa Naukowo-Techniczne, Warszawa 2007.

http://stat.gov.pl/obszary-tematyczne/infrastruktura-komunalna-nieruchomosci/ nieruchomosci-budynki-infrastruktura-komunalna/infrastruktura-komunalna-w-2014-r-,3,12.html. 


\section{Rozdział 11}

\section{Inżynieria środowiska w ochronie wód Technologie oczyszczania ścieków}

\subsection{Zanieczyszczenia wód}

Woda jest jednym z najważniejszych zasobów naturalnych i odgrywa kluczową rolę w rozwoju społeczno-gospodarczym każdego kraju. Postępujący rozwój cywilizacji, a zwłaszcza związany z nim rozwój przemysłu, powoduje degradację zasobów wodnych, głównie wód powierzchniowych. Dlatego problematyka ochrony i efektywnego gospodarowania zasobami wodnymi jest obecnie bardzo często podejmowana na szczeblu zarówno europejskim, jak i krajowym, a przywracanie czystości wód jest jednym z najwyższych priorytetów w sektorze ochrony środowiska w Polsce i innych krajach Unii Europejskiej. W związku z tym, zgodnie z wymaganiami zawartymi w obowiązujących unijnych dyrektywach w zakresie gospodarki wodnej oraz oczyszczania ścieków komunalnych, podjęto szereg działań zmierzających do poprawy stanu wód, w tym przede wszystkim na rzecz budowy systemów zbierania ścieków oraz oczyszczalni ścieków. Istotne jest racjonalne gospodarowanie wodami, ale także tworzenie jak najbardziej stabilnych systemów zaopatrzenia w wodę i odbioru nieczystości ciekłych. Wszystkie działania podjęte w zakresie gospodarki wodno-ściekowej powinny być przyjazne dla środowiska, gospodarki i społeczeństwa, zgodnie z zasadami zrównoważonego rozwoju.

Najogólniej zanieczyszczenia występujące w wodach można podzielić na naturalne oraz zanieczyszczenia powstałe w wyniku działalności człowieka. Zanieczyszczenia naturalne stanowią organiczne resztki przedostające się do zbiorników wodnych, które wpływają na zmianę składu chemicznego i fizycznego wody. Niewielka ilość tych zanieczyszczeń może być w sposób naturalny unieszkodliwiona w procesach samoodbudowy i samooczyszczenia, szczególnie w rzekach. W jeziorach zdolność ta jest znacznie mniejsza i zanieczyszczenia gromadzą się tam szybciej. Jednakże kiedy w wodach pojawią się zanieczyszczenia spowodowane działalnością człowieka w nadmiarze (bezpośrednio wprowadzone 
do wód lub także z powietrza i gleby), zdolność samooczyszczania wód może być niewystarczająca. Nadmiar zanieczyszczeń może spowodować zachwianie równowagi biologicznej i w efekcie także skażenie wody.

Ze względu na miejsce powstawania zanieczyszczeń antropogenicznych $w$ postaci ścieków dzielimy je na: komunalne, przemysłowe oraz rolnicze. Zanieczyszczenia komunalne są mieszaniną odpadów z gospodarstw domowych, fekaliów, odpadów ze szpitali, łaźni, pralni i zakładów przemysłowych. Wśród zanieczyszczeń w ściekach (w postaci zawiesiny lub w postaci rozpuszczonej) występują związki organiczne (białka, tłuszcze i węglowodany), detergenty, chorobotwórcze drobnoustroje, a także metale ciężkie (głównie ołów, rtęć). Substancje te, jeśli dostaną się do organizmów żywych, mogą powodować wiele chorób, w tym także zagrażających życiu.

Zanieczyszczenia przemysłowe powstają podczas procesów produkcyjnych. Skład tych ścieków jest bardzo zróżnicowany i zależy od rodzaju produkcji. Przykładowo ścieki z garbarni zawierają wiele bardzo szkodliwych dla organizmów żywych substancji chemicznych, na przykład związki wapnia, chromu, siarczki, chlorki, związki azotu, a także tłuszcze i inne związki organiczne.

$\mathrm{Na}$ zanieczyszczenia rolnicze składają się przede wszystkim środki ochrony roślin, które niszcząc szkodliwe organizmy, jednocześnie niszczą również organizmy pożyteczne. Nadmiar nawozów sztucznych może doprowadzić do zakłócenia równowagi ekologicznej w ekosystemach wodnych.

\subsection{Ochrona wód. Rekultywacja i renaturyzacja}

W ramach ochrony zasobów wodnych wyróżnia się ochronę ilościową i jakościową. Istotą ochrony ilościowej jest racjonalna eksploatacja wody z zasobu naturalnego. Polega ona na zachowaniu równowagi hydrodynamicznej między ilością wody czerpanej a zasilaniem zasobu. W celu nadzorowania poborów wody stosowane są dwa podstawowe instrumenty: pozwolenia wodno-prawne oraz system opłat środowiskowych. Istotne w tym względzie są także takie działania, jak na przykład dokonywanie systematycznych pomiarów ilości pobieranej wody przez zakłady czy też zapobieganie marnotrawstwu wody w gospodarstwach domowych.

Natomiast celem jakościowej ochrony wód jest zabezpieczenie ich przed emisją różnego rodzaju szkodliwych substancji chemicznych, po- 
chodzących ze źródeł punktowych i obszarowych. Również w tym przypadku ważną funkcję pełnią pozwolenia wodno-prawne oraz system środków finansowo-prawnych, a w szczególności opłaty środowiskowe i kary administracyjne. Instrumenty te służą kontroli podmiotów wprowadzających ścieki do wód lub do ziemi. Ze względu na rodzaj podejmowanych działań ochronę zasobów wodnych dzieli się na bierną i czynną. Celem ochrony biernej wód jest utrzymywanie lub poprawa jakości wód oraz biologicznych stosunków w środowisku wodnym i na terenach podmokłych. Prowadzone w tym zakresie działania powinny zapewnić przydatność wód do zaopatrzenia ludności w wodę przeznaczoną do spożycia, rekreacji, uprawiania sportów wodnych, bytowania ryb i innych organizmów. Do realizacji tych celów konieczne jest przestrzeganie zakazu odprowadzania ścieków bezpośrednio do wód podziemnych, powierzchniowych oraz stojących (np. jezior), a także do ziemi. Zakazu wprowadzania do ziemi należy przestrzegać szczególnie wtedy, gdy stopień oczyszczania ścieków lub miąższość utworów skalnych nad zwierciadłem wód podziemnych nie stanowi zabezpieczenia tych wód przed zanieczyszczeniem. W odniesieniu do wód powierzchniowych natomiast nie wolno wprowadzać ścieków, jeżeli jest to sprzeczne z warunkami wynikającymi z istniejących form ochrony przyrody, utworzonych stref ochrony zwierząt łownych albo ostoi, a także stref ochronnych ujęć wód i obszarów ochronnych głównych zbiorników wód podziemnych.

Czynna ochrona wód opiera się na stosowaniu urządzeń, które umożliwiają oczyszczanie ścieków przed ich wprowadzeniem do odbiornika. Jednym z nadrzędnych obowiązków w tym zakresie, jakie spoczywają na wprowadzających ścieki do wód lub do ziemi, jest zapewnienie ochrony wód przed zanieczyszczeniem, w szczególności przez budowę i eksploatację urządzeń służących tej ochronie, a tam gdzie jest to celowe, powtórne wykorzystanie oczyszczonych ścieków.

W ochronie wód stosuje się wiele rozwiązań, a najbardziej typowe rozwiązania techniczne to:

- stosowanie bezściekowych technologii w produkcji przemysłowej;

- napowietrzanie wód stojących;

- zamykanie obiegów wodnych w cyklach produkcyjnych i odzysk wody ze ścieków;

- utylizacja wód kopalnianych oraz powtórne wtłaczanie tych wód do górotworu; 
- zabezpieczanie hałd i wysypisk śmieci;

- oczyszczanie ścieków i unieszkodliwianie osadów ściekowych;

- budowa małych oczyszczalni przydomowych.

W wielu krajach w celu zmniejszenia wydatku objętościowego wody $w$ procesach produkcyjnych wdrażane są ekoinnowacyjne rozwiązania z wykorzystaniem technologii środowiskowych, w których stosuje się na przykład powtórne użycie wody z jednej operacji do innej, powtórne użycie wody do innej operacji po uprzednim jej oczyszczeniu lub odnowę wody i jej zawracanie do poprzednich procesów w obiegu zamkniętym.

Od wielu lat jednym z priorytetów unijnej polityki w zakresie ochrony wód jest budowa systemów kanalizacji zbiorczej i oczyszczalni ścieków, a także efektywne zagospodarowywanie ścieków pochodzących z gospodarstw domowych na terenach niezurbanizowanych. Podkreśla się jednak, że jeśli na terenie danej gminy budowa sieci kanalizacyjnej jest technicznie lub ekonomicznie nieuzasadniona, celowe jest wyposażenie nieruchomości w przydomową oczyszczalnię ścieków lub w zbiornik bezodpływowy (tzw. szambo).

W celu odnowy zdegradowanego środowiska wodnego, czyli przywrócenia jego poprzednich funkcji, a także cech fizycznych, chemicznych i biologicznych, zbliżonych do naturalnych, przeprowadza się rekultywację wód. Ze względu na rosnące zapotrzebowanie na wodę jest bardzo prawdopodobne, że w przyszłości celem rekultywacji może stać się poprawa jakości wody w zbiorniku, tak by mogła być ona źródłem wody pitnej oraz służyć do produkcji żywności. Programy rekultywacyjne cechują się jednak wysokimi kosztami i są często kłopotliwe w realizacji, a przy tym nie zawsze w pełni skuteczne.

Metody rekultywacyjne można podzielić na dwie podstawowe grupy: techniczne i biologiczne. Do metod rekultywacji technicznej zalicza się: aerację toni wodnej i osadów dennych, wymianę wody w zbiorniku, usuwanie wód hypolimnionu, wytrącanie związków fosforu i ich inaktywację, wapnowanie, bagrowanie, stosowanie środków glonobójczych i wiele innych. Rekultywacja biologiczna obejmuje takie metody jak: odłów sestonu, odłów ryb, wykaszanie roślinności, wykorzystanie organizmów poroślowych, biomanipulację i inne. Poniżej krótko scharakteryzowano kilka wybranych metod rekultywacji technicznej. 
Aeracja toni wodnej i osadów dennych jest najstarszą oraz jednocześnie najbardziej rozpowszechnioną metodą stosowaną w celu rekultywacji zbiorników wodnych w wielu krajach, choć w Polsce nie jest tak popularna. Możliwe jest prowadzenie tej metody na dwa sposoby: z jednoczesnym zaburzeniem stratyfikacji termicznej (uwarstwienia termicznego) oraz napowietrzaniem wód bez zaburzenia stratyfikacji. W pierwszym wypadku doprowadza się sprężone powietrze do najgłębszego miejsca w jeziorze lub cieku wodnym. Pęcherzyki powietrza unoszące się w górę wypychają wody naddenne na powierzchnię, gdzie następuje ich ogrzanie i natlenienie. Wracają one do dolnej warstwy w jeziorach, ale już do warstw położonych na mniejszej głębokości. Metoda ta jest stosunkowo kosztowna ze względu na znaczący pobór energii elektrycznej.

Wymiana wody w zbiorniku polega na usunięciu wody w całości lub części i zastąpieniu jej dostarczoną z innego źródła wodą czystą. Zabieg przeprowadza się za pomocą przepłukiwania zbiornika lub w miarę możliwości usunięcia wody i samorzutnego napełnienia się zbiornika wodami gruntowymi lub innymi czystymi wodami. Metodę zaleca się dla bardzo małych zbiorników wodnych, doraźnie zanieczyszczonych lub takich, w których zanieczyszczenia nie są skumulowane w osadach dennych.

Zabieg usuwania wód dolnej warstwy jeziora poza zbiornik przeprowadza się za pomocą odpowiednio dobranej rury wprowadzonej blisko dna. Rekultywowane jezioro lub ciek wodny musi mieć charakter przepływowy. Pomimo iż w cieku odprowadzającym wody ulegają naturalnym procesom samooczyszczania, nie poleca się tej metody w przypadku szczególnie wysokiego zanieczyszczenia wód. Proces jest stosunkowo długotrwały, a efekty są widoczne dopiero w dłuższym okresie.

Wytrącenie związków fosforu i ich inaktywację stosuje się do osadów dennych jedynie w małych zbiornikach wodnych o małym falowaniu (np. osłoniętych, izolowanych zatok). Proces odbywa się za pomocą związków żelaza i glinu wprowadzanych w formie granulatu lub specjalnie przygotowanych roztworów. Kilkukrotne wprowadzanie małych dawek koagulantu przyczynia się do stopniowej poprawy warunków i stabilizacji środowiska jeziora.

Bagrowanie zbiornika lub cieku wodnego polega na usuwaniu warstwy osadów dennych wraz z wyrastającą z nich roślinnością. Metodę tę stosuje się w przypadku zbiorników charakteryzujących się występowaniem intensywnych zakwitów glonów. Jest jedną z najefektywniejszych 
metod, pozwala na przywrócenie funkcji rekreacyjnych zbiornika, a wraz $z$ osadami usuwane są zgromadzone $w$ nich substancje niebezpieczne. Jest jednak stosunkowo kosztowna i skomplikowana.

Wiele ekosystemów wodnych i wodno-zależnych jest obecnie tak silnie zmienionych i zdegradowanych, że nawet ich najściślejsza ochrona nie spowoduje poprawy ich stanu. W wielu przypadkach konieczne jest podjęcie działań określanych mianem renaturyzacji. Jest to zespół przedsięwzięć mających na celu przywrócenia rzekom, jeziorom, dolinom naturalnego charakteru ich walorów krajobrazowych i przyrodniczych. Wśród tych działań wymienić można:

- oczyszczanie jezior;

- odtwarzanie i budowę niewielkich zbiorników wodnych;

- przywracanie naturalnego charakteru cieków, w tym trwałą deregulację powiązaną z rozbieraniem zbędnych urządzeń wodnych;

- przywracanie zalewów poprzez likwidację lub odsuwanie od koryt rzek wałów przeciwpowodziowych;

- przywracanie łączności z rzeką odciętych sztucznie starorzeczy;

- poprawę uwilgotnienia torfowisk;

- czynną ochronę torfowisk poprzez hamownie sukcesji i krzewów na skutek przesuszenia;

- przywracanie ekstensywnych form użytkowania pastwiskowego i łąkowego;

- restytucje roślinności torfotwórczej na torfowiskach;

- działania skierowane na konkretne gatunki związane z mokradłami.

Renaturyzacja rzek dotyczy działań z zakresu inżynierii wodnej i ochrony środowiska, dzięki którym rzeki nadmiernie przekształcone odzyskują część swoich poprzednich, naturalnych cech. Działania te mogą być realizowane w różnych strefach: w korycie rzeki, strefie brzegowej, na terenie doliny, na dopływach i w obszarze zlewni. Natomiast w przypadku jezior proces odnowy przebiega w inny sposób i działania renaturyzacyjne sku- 
piają się raczej na usunięciu fosforu, który jest główną przyczyną zjawiska eutrofizacji.

Wprawdzie renaturyzacja ma zazwyczaj ograniczony zakres i nie przywraca stanu cieku wodnego sprzed okresu nadmiernej eksploatacji, przynosi jednak wymierne korzyści społeczne, ekonomiczne i środowiskowe. Oczywiście w każdym przypadku renaturyzacji należy przeprowadzić rachunek ekonomiczny w ochronie środowiska i przyjąć wariant najodpowiedniejszy z punktu widzenia ekonomii i ochrony renaturyzowanych zasobów wodnych. Renaturyzacja jest bowiem procesem stosunkowo kosztownym, a oprócz tego inwestycje tego rodzaju wymagają nie tylko nakładów finansowych, ale także zaawansowanej specjalistycznej wiedzy technicznej oraz przyrodniczej.

Należy wspomnieć o jeszcze jednym typie działań naprawczych, a mianowicie restytucji przyrodniczej. Są to działania wspomagające odtwarzanie się ekosystemu, który uległ degradacji lub zniszczeniu, poprzez odbudowę jego funkcji i struktury. Restytucja rzek to między innymi odtwarzanie dolinowej retencji wody, zdolności do samooczyszczania wody, dynamiki ekosystemów dolin rzecznych czy odporności ekosystemu na zmiany środowiska. Obecna strategia ochrony bioróżnorodności biologicznej UE wymaga restytucji 15\% zdegradowanych ekosystemów do 2020 roku.

\subsection{Rodzaje ścieków}

Nowoczesne metody inżynieryjne oraz innowacyjne technologie środowiskowe odgrywają bardzo ważną rolę w ochronie wód powierzchniowych i podziemnych, przede wszystkim ze względu na ich wykorzystanie w procesach oczyszczania ścieków. Ścieki i osady ściekowe wprowadzane do wód bez odpowiedniego oczyszczenia wywierają bowiem szczególnie niekorzystny wpływ na jakość tych wód. W wyniku zastosowania efektywnych metod oczyszczania znacznie obniża się ładunek zanieczyszczeń w ściekach, czyli masa zanieczyszczeń zawartych w ściekach odprowadzona w jednostce czasu, równa iloczynowi natężenia przepływu ścieków i stężenia zanieczyszczeń.

Ze względu na pochodzenie źródła zanieczyszczenia można wydzielić ścieki: bytowo-gospodarcze, przemysłowe, opadowe, zanieczyszczenia z wód przypadkowych i drenażowych, miejskie oraz pochodzenia rolniczego. 
Ścieki bytowo-gospodarcze powstają w gospodarstwach domowych oraz w obiektach użyteczności publicznej. Składają się na nie wody zużyte do spłukiwania ustępów, kąpieli, prania, mycia naczyń, przygotowywania posiłków, mycia pomieszczeń czy samochodów. Ich ilość w przybliżeniu odpowiada zużytej ilości wody wodociągowej. Ścieki te zawierają duże ilości żywych drobnoustrojów i wprowadzone do wód powierzchniowych w postaci surowej powodują nadmierną eutrofizację. Mogą także zawierać szkodliwe dla wód substancje powierzchniowoczynne.

Ścieki miejskie są mieszaniną ścieków bytowo-gospodarczych, przemysłowych, wód infiltracyjnych i przypadkowych, a w wypadku kanalizacji ogólnospławnej - także ścieków opadowych oraz z polewania ulic i placów. Ich skład zależy od charakteru i wielkości miasta, stopnia jego uprzemysłowienia, wielkości terenów zielonych oraz sposobu użytkowania terenów rolnych i leśnych. Ze względu na to, że są to ścieki pochodzące między innymi także ze szpitali, mogą stanowić poważne źródło zanieczyszczeń higienicznych czy epidemiologicznych.

Ścieki przemysłowe pochodzą z procesów produkcyjnych występujących w prawie każdej dziedzinie przemysłu. Są to więc wszelkie ścieki odbierane z terenów, na których prowadzi się działalność gospodarczą, które nie są ściekami bytowo-gospodarczymi, spływem wód opadowych, przypadkowych lub drenażowych. Powstają w procesach produkcyjnych, przy otrzymywaniu, uszlachetnianiu i przeróbce surowców pochodzenia organicznego i mineralnego, a także podczas mycia, transportu wodnego, chłodzenia oraz wielu innych zabiegów. Mogą zawierać wiele niebezpiecznych substancji chemicznych - związków mineralnych i organicznych w różnym stanie skupienia (np. kwasy, zasady, sole metali ciężkich, cyjanki, trujące związki organiczne, tłuszcze, białka, oleje, substancje utleniające lub redukujące, fenole, smoły, barwniki, ropę naftową, rodanki, związki siarki i inne). Ilość i rodzaj zanieczyszczeń w ściekach zależą od aparatury przedsiębiorstwa, technologii produkcji, ilości zużywanej wody, aparatury i instalacji produkcyjnych.

Ścieki opadowe powstają w czasie trwania opadów, kiedy składniki powietrza są wymywane i rozpuszczane przez wody opadowe, a następnie w postaci mieszaniny spływają po powierzchni ziemi jako ścieki opadowe. Ścieki te wymywają dalsze zanieczyszczenia pochodzące z procesów ścierania nawierzchni ulic, opon, utrzymania ulic, wymywania środków ochrony roślin i nawozów. Wymywane są wraz z tymi ściekami także drobne uliczne odpady. 
Zanieczyszczenia z wód przypadkowych i drenażowych powstają w wyniku przedostawania się do kanalizacji wód podziemnych będących w zasięgu oddziaływania, tudzież w wyniku celowego skierowania do kanalizacji wód pochodzących z wykopów budowlanych lub awarii sieci wodociągowej. Zaliczamy do nich także ścieki opadowe dostające się do kanalizacji przez włazy, przewietrzniki, wpusty uliczne i podwórzowe oraz wody gruntowe z sieci drenażowej, odcieki ze składowisk odpadów i silosów kiszonkowych.

$\mathrm{Na}$ obszarach wiejskich ścieki powstają w wyniku zużycia wody na cele bytowo-gospodarcze, produkcyjne oraz z wód opadowych. Ścieki pochodzenia rolniczego powstają ze spływu z podwórzy, gnojowisk, a także dużych zakładów chowu drobiu. Działanie tych ścieków przypomina działanie ścieków bytowo-gospodarczych. Ścieki produkcyjne powstają w wyniku zużycia wody głównie w zakładach przetwórstwa rolno-spożywczego oraz w produkcji zwierzęcej. Ścieki te określa się ogólnie jako przemysłowe. Szczególnie niebezpieczną grupą zanieczyszczeń w tych ściekach są pestycydy oraz gnojowica.

Ścieki radioaktywne pochodzą z zakładów naukowych, leczniczych, zakładów reaktorów atomowych i wielu innych. Ścieki te są bardzo groźne, dlatego są one zatapiane w tzw. betonowych skrzyniach lub topielnikach.

\subsection{Rodzaje oczyszczalni ścieków}

Pod pojęciem oczyszczania ścieków należy rozumieć wszelkie działania, które służą usunięciu szkodliwych zanieczyszczeń biologicznych, chemicznych i mechanicznych ze ścieków, aby nie stanowiły one już zagrożenia dla organizmów żywych i środowiska naturalnego. Głównym celem oczyszczania ścieków jest ochrona środowiska naturalnego człowieka, a przede wszystkim ochrona czystości wód powierzchniowych.

Oczyszczalnie ścieków stanowią technologiczne obiekty budowlane. Jest to zespół urządzeń przeznaczonych do oczyszczania ścieków, czyli do eliminacji substancji, które zostały w tych ściekach rozpuszczone, przed odprowadzeniem ich do rzeki, morza czy gruntu. Stopień obciążenia oczyszczalni jest to wyrażony w procentach stosunek ilości ścieków oczyszczanych do przepustowości urządzeń oczyszczalni. Wskaźnik wyższy od $100 \%$ oznacza przeciążenie urządzeń oczyszczalni. Natomiast stopień redukcji zanieczyszczeń w ściekach jest to wyrażona w procentach redukcja ładunków zanieczyszczeń w ściekach w wyniku zastosowania procesów oczyszczania. 
W zależności od ilości oczyszczanych ścieków wyróżniamy oczyszczalnie lokalne (przeznaczone do oczyszczania niewielkich ilości ścieków), centralne (do dużych ilości) i grupowe (z wyznaczonego regionu). Ze względu na sposób oczyszczania ścieków oczyszczalnie ścieków można podzielić na trzy zasadnicze rodzaje: mechaniczne, biologiczne i chemiczne. Najczęściej stosuje się kilkustopniowe oczyszczanie ścieków, na przykład oczyszczanie ścieków mechaniczne i biologiczne lub mechaniczno-chemiczno-biologiczne, które zakwalifikowano do wyższego stopnia oczyszczania. Podwyższone usuwanie biogenów (związków azotu i fosforu) ze ścieków następuje w oczyszczalniach o wysoko efektywnych technologiach oczyszczania, umożliwiających zwiększoną redukcję tych pierwiastków.

Oczyszczanie mechaniczne, często nazywane oczyszczaniem wstępnym, zachodzi w wyniku stosowania procesów fizycznych, takich jak na przykład rozdrabnianie większych ciał stałych, filtrowanie czy cedzenie. Polega na usuwaniu dużych, ciężkich oraz lekkich oleistych zanieczyszczeń nierozpuszczalnych, tj. ciał stałych (np. piasku) i tłuszczów ulegających sedymentacji lub flotacji. W procesie sedymentacji cząsteczki opadają pod wpływem siły ciężkości. W ostatnim etapie pracy oczyszczalni mechanicznej zachodzi klarowanie, czyli oddzielenie zawiesin od cieczy poprzez filtrowanie. Do wspomagania procesu filtracji stosuje się polielektrolity (flokulanty). W całej metodzie stosowane są następujące urządzenia: kraty i sita (rys. 11.1), odtłuszczowniki (flotatory), piaskowniki (rys. 11.2), osadniki i filtry.

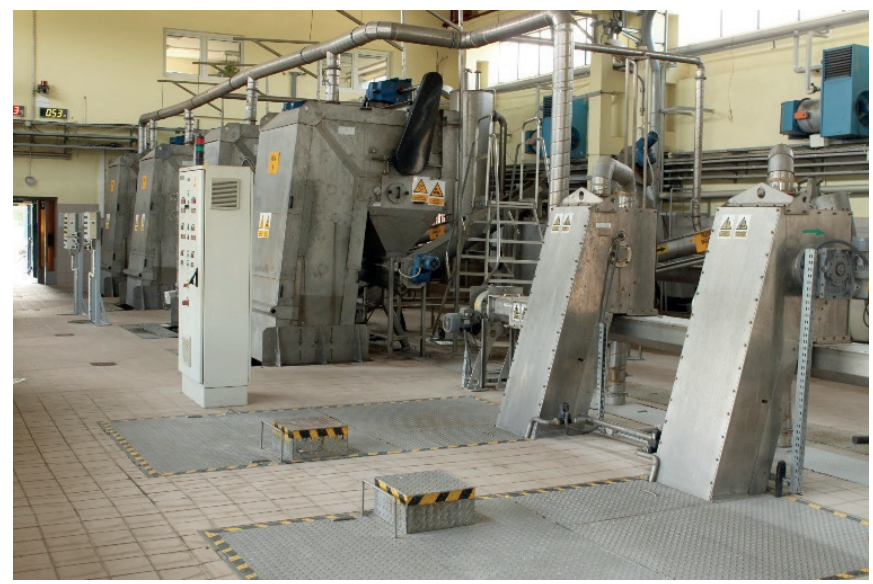

Rys. 11.1. Hala krat

Źródło: Archiwum Grupowej Oczyszczalni Ścieków w Łodzi Sp. z o. o. 
Kraty służą do wstępnego cedzenia ścieków, dzięki czemu następuje usunięcie ze ścieków zanieczyszczeń stałych o dużych rozmiarach. Mogą być: ruchome, nieruchome, gęste, średnie i rzadkie. Oprócz krat używa się także sita oraz mikrosita.

Za pomocą piaskowników usuwa się: piaski, żużel, szklaną stłuczkę, węgiel, drobny miał z koksu i wiele innych pyłów. Piaskowniki dzielimy na kilka typów: z przepływem poziomym, z przepływem pionowym, szczelinowe, z okrężnym ruchem cieczy oraz piaskowniki przedmuchiwane. Piaskowniki ostatniego typu są stosowane w oczyszczalniach dużych miast. Na rysunku 11.2. przedstawiono zdjęcie piaskownika z przepływem poziomym.

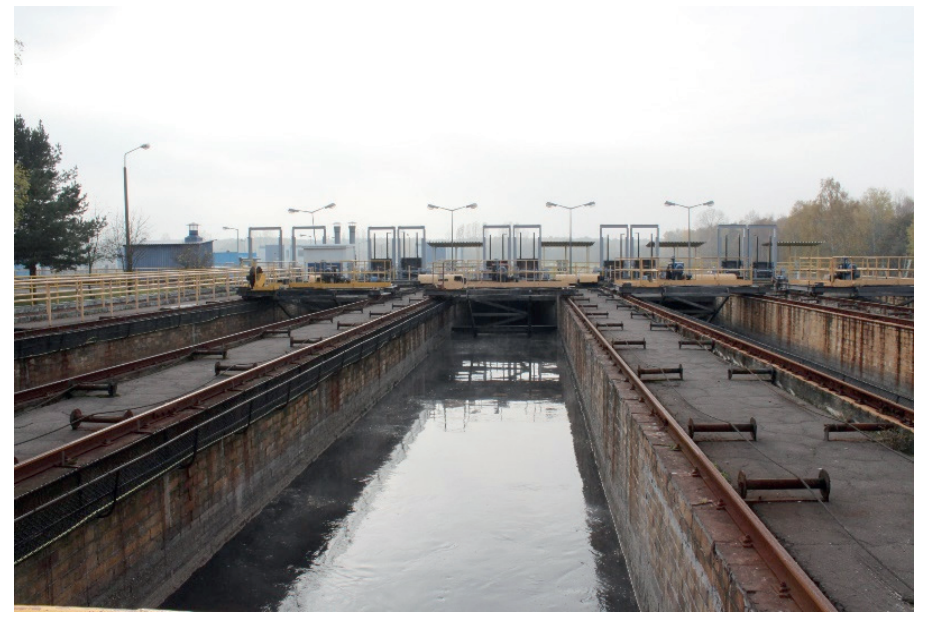

Rys. 11.2. Piaskownik

Źródło: Archiwum Grupowej Oczyszczalni Ścieków w Łodzi Sp. z o. o.

Osadniki to obiekty, które służą do usuwania ze ścieków zawiesin łatwo opadających na dno. Używa się ich zazwyczaj do wstępnego oczyszczania ścieków przemysłowych oraz pochodzących z zakładów usługowych. Podczas kolejnych etapów oczyszczania miejskich ścieków stosowane są osadniki wstępne, pośrednie oraz wtórne. W osadniku wstępnym z podczyszczonych na kratach i w piaskowniku ściekach oddziela się drobniejsze zawiesiny.

Urządzenia odtłuszczające i odolejające wykorzystywane są do usuwania ze ścieków wszelkich substancji oleistych i tłustych. Działają one 
na zasadzie flotacji, czyli wypływania na powierzchnię cząsteczek lżejszych od wody, tworzących kożuch albo błonę.

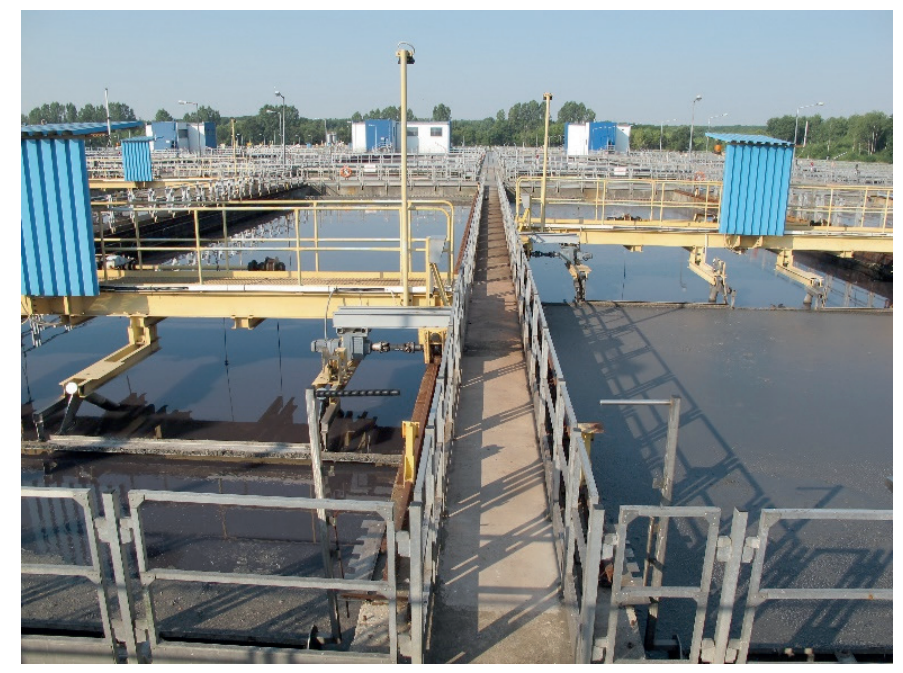

Rys. 11.3. Osadnik wtórny

Źródło: Archiwum Grupowej Oczyszczalni Ścieków w Łodzi Sp. z o. o.

Chemiczne oczyszczanie ścieków polega na wytrącaniu niektórych związków rozpuszczalnych, względnie ich neutralizacji metodami chemicznymi, takimi jak koagulacja czy sorpcja na węglu aktywnym przy udziale związków chemicznych. Zachodzą wtedy reakcje chemiczne (utlenianie, redukcja, wytrącanie, zobojętnianie, wymiana jonowa), które mają na celu zmniejszenie ilości zanieczyszczeń.

W zależności od składu i ilości ścieków do ich oczyszczania stosuje się wiele różnych procesów fizycznych i chemicznych. Metody stosowane głównie w stosunku do ścieków zawierających dużą ilość zanieczyszczeń, najczęściej przemysłowych to: koagulacja, sorpcja, ekstrakcja, odgazowanie, wymrażanie, dezynfekcja, neutralizacja, utlenianie czy redukcja chromu. Wykorzystuje się też techniki membranowe.

W procesie neutralizacji zachodzi chemiczne zobojętnianie ścieków o odczynie kwaśnym lub zasadowym, z użyciem aktywnych jonów, zasad lub kwasów. Często stosowaną metodą jest doprowadzenie do zmieszania ścieków o kwaśnym odczynie ze ściekami o odczynie zasadowym przy udziale specjalnych reagentów. 
W procesach chemicznych utlenia się związki organiczne i nieorganiczne oraz dezynfekuje ścieki. Chemiczne zapotrzebowanie tlenu (ChZT) jest to ilość tlenu pobrana w procesie chemicznego utleniania ścieków. Dzięki utlenianiu unieszkodliwia się między innymi toksyczne cyjanki, a także fenole, aminy, kwasy humusowe, glony, wirusy i bakterie. Do utleniania służą przede wszystkim chlor i ozon.

Koagulacja umożliwia usunięcie ze ścieków zawiesin trudno opadających, bakterii i koloidów. W procesach koagulacji stosowane są najczęściej następujące koagulanty: siarczan glinu, siarczan żelaza, chlorek żelaza, wapno hydratyzowane i palone oraz glinian sodu. Strącanie wykorzystuje się do usuwania metali, natomiast ekstrakcję do oddzielenia od ścieków fenoli, by następnie je usunąć.

Biologiczne oczyszczanie ścieków, szczególnie ważne w technologii oczyszczania ścieków, następuje w procesie mineralizacji przez drobnoustroje w środowisku wodnym i polega na usuwaniu ze ścieków biologicznie rozkładalnych zanieczyszczeń organicznych oraz związków biogennych i refrakcyjnych, czyli głównie związków azotu, fosforu i zawiesin.

Jednym z głównych wskaźników stopnia zanieczyszczenia ścieków na dopływie do oczyszczalni lub ścieków odprowadzanych do odbiornika z oczyszczalni jest biochemiczne zapotrzebowanie tlenu (BZT $\left.{ }_{5}\right)$. Jest to ilość tlenu zużyta w ciągu pięciu dni w procesie biochemicznego utleniania substancji organicznych zawartych w ściekach, z użyciem żywych bakterii i enzymów pozakomórkowych. Określony w definicji okres pięciu dni jest zasadny, ponieważ procesy mineralizacji najbardziej intensywnie przebiegają właśnie w takim czasie. Natomiast równoważna liczba mieszkańców (RLM) wyraża wielokrotność ładunku zanieczyszczeń w ściekach w stosunku do jednostkowego ładunku w ściekach odprowadzonych od jednego mieszkańca w ciągu doby (określonego jako BZT ${ }_{5}$ ), równego $60 \mathrm{~g} \mathrm{O}_{2}$ na dobę ${ }^{1}$.

W technologii biologicznego oczyszczania ścieków wyróżnia się metody naturalne i sztuczne, w których procesy mogą być prowadzone w warunkach tlenowych oraz beztlenowych. Do metod zbliżonych do naturalnego oczyszczania zaliczamy:

1. W warunkach tlenowych:

- pola filtracyjne, tzw. filtry glebowe;

- stawy napowietrzane;

www.stat.gov.pl. 
- oczyszczalnie roślinne, do których zaliczamy: złoża torfowe, stawy glonowe, oczyszczalnie korzeniowe oraz filtry z roślin wodnych;

- metody rolniczego wykorzystania - np. stawy rybne lub pola nawadniane.

2. W warunkach beztlenowych:

- doły gnilne;

- stawy stabilizacyjne;

- laguny.

Natomiast metody sztuczne stosowane w oczyszczalniach biologicznych to w warunkach tlenowych metoda osadu czynnego oraz złóż biologicznych, natomiast w warunkach beztlenowych doły i komory fermentacyjne (otwarte i zamknięte).

W procesach biologicznego rozkładu zanieczyszczeń organicznych wykorzystuje się mikroorganizmy zawieszone w toni ścieków (w technologii osadu czynnego) lub mikroorganizmy tworzące utwierdzoną biomasę (w złożach biologicznych). Mikroorganizmy wykorzystują zanieczyszczenia jako pokarm, dzięki czemu następuje przyrost biomasy bakteryjnej. W procesach beztlenowych produktami gazowymi rozkładu materii organicznej są dwutlenek węgla oraz metan. Nadmiar masy organicznej wytworzonej podczas rozkładu biologicznego zanieczyszczeń oddzielany jest od strumienia ścieków w osadnikach wtórnych.

Obecnie najpopularniejszą technologią oczyszczania ścieków jest metoda osadu czynnego, która polega na sztucznie spotęgowanym procesie samooczyszczania wody w rzekach i jeziorach. Zastosowano tutaj specjalne komory napowietrzające, w których hoduje się drobnoustroje stanowiące osad czynny. Drobnoustroje, czyli bakterie i pierwotniaki znajdujące się w środowisku tlenowym, karmią się substancjami odżywczymi zawartymi w oczyszczanych ściekach. Substancje te zostają wbudowane w strukturę osadu lub są utleniane do $\mathrm{CO}_{2} \mathrm{i}$ innych związków niskocząsteczkowych. Istnieje wiele rozwiązań konstrukcyjnych i typów komór osadu czynnego. Konstrukcję przykładowej komory biologicznej osadu czynnego bez zawartości w postaci ścieków przedstawia rysunek 11.4 . 


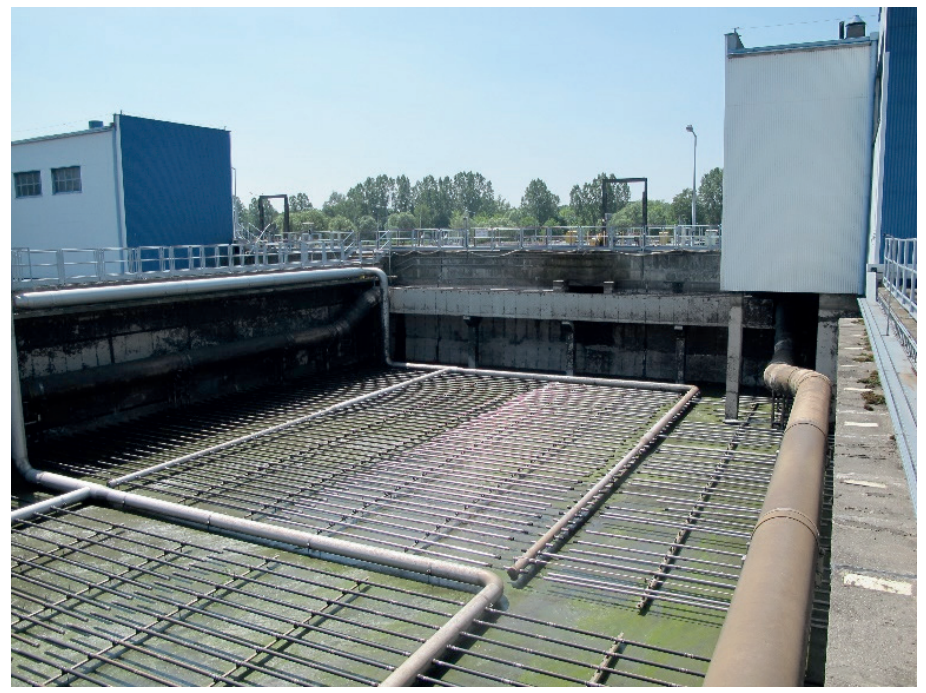

Rys. 11.4. Komora biologiczna osadu czynnego z systemem napowietrzającym Źródło: Archiwum Grupowej Oczyszczalni Ścieków w Łodzi Sp. z o. o.

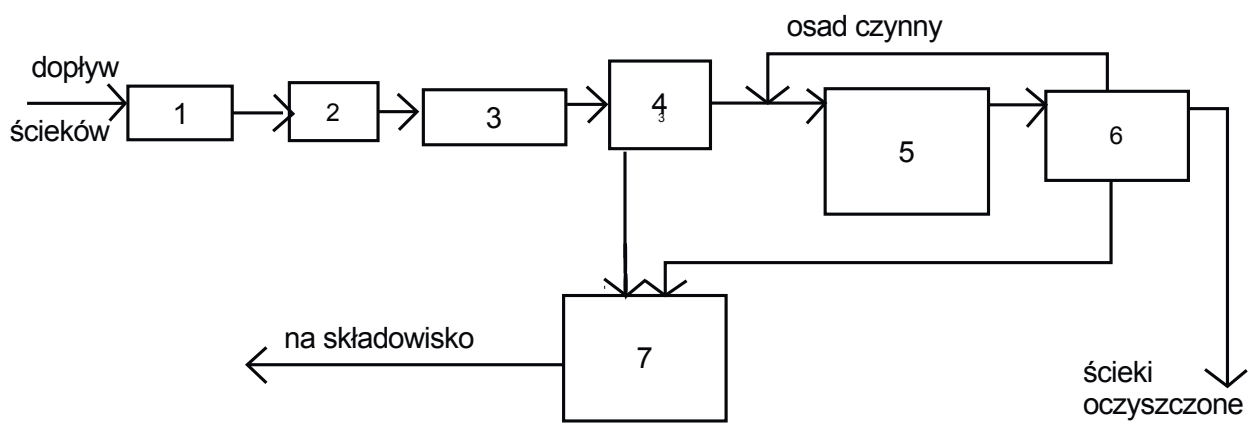

Rys. 11.5. Przykładowy schemat technologiczny pełnego układu oczyszczania ścieków z wykorzystaniem osadu czynnego

Oznaczenia: 1 - krata, 2 - pompownia, 3 - piaskownik, 4 - osadnik wstępny, 5 - komora osadu czynnego, 6 - osadnik wtórny, 7 - komora tlenowej stabilizacji

Źródło: opracowanie własne na podstawie: Czempińska-Świtalska Z. i in., Gospodarka wodno-ściekowa, PWSOŚ, Radom 1998, s. 40-41 oraz R. Zarzycki i in., Wprowadzenie do inżynierii i ochrony środowiska, t. 1: Ochrona środowiska naturalnego, Wydawnictwa Naukowo-Techniczne, Warszawa 2007, s. 325 
Na rysunku 11.5 zamieszczono przykładowy schemat technologiczny pełnego układu oczyszczania ścieków z zastosowaniem technologii osadu czynnego. Ścieki dopływają do oczyszczalni systemem kolektorów. W pierwszym etapie zanieczyszczenia o największych rozmiarach są usuwane na kratach. Następnie ścieki przepływają przez piaskownik i osadnik wstępny w celu oddzielenia zawiesin. W dalszym etapie ścieki są kierowane do komór osadu czynnego, a potem przepływają do osadnika wtórnego, skąd jako oczyszczone wody odprowadzane są do wód powierzchniowych stanowiących odbiornik.

Złoże biologiczne stanowi hodowlę bakterii i pierwotniaków, która jest prowadzona w środowisku tlenowym. Hodowla ta jest osadzona na warstwie wypełnienia, którym mogą być kamienie, żwir, żużel, kostki ceramiczne lub kraty drewniane. Zraszane i napowietrzane ściekami złoże biologiczne pokrywa się po kilku tygodniach śluzowatymi organizmami bakteryjnymi. Mikroorganizmy na drodze biosorpcji gromadzą na swej powierzchni składniki pożywienia i włączają je w cykl przemian biochemicznych. Powstała w ten sposób błona biologiczna, która pokrywa elementy wypełnienia, nie powinna być grubsza niż 2-3 mm. Stosuje się obecnie następujące typy i rodzaje złóż biologicznych: klasyczne spłukiwane (wysoko obciążone), zraszane (niskoobciążone), przemienne, wieżowe, zanurzone (z utwierdzoną biomasą), a także tarczowe. Rysunek 11.6 prezentuje złoża biologiczne zraszane.

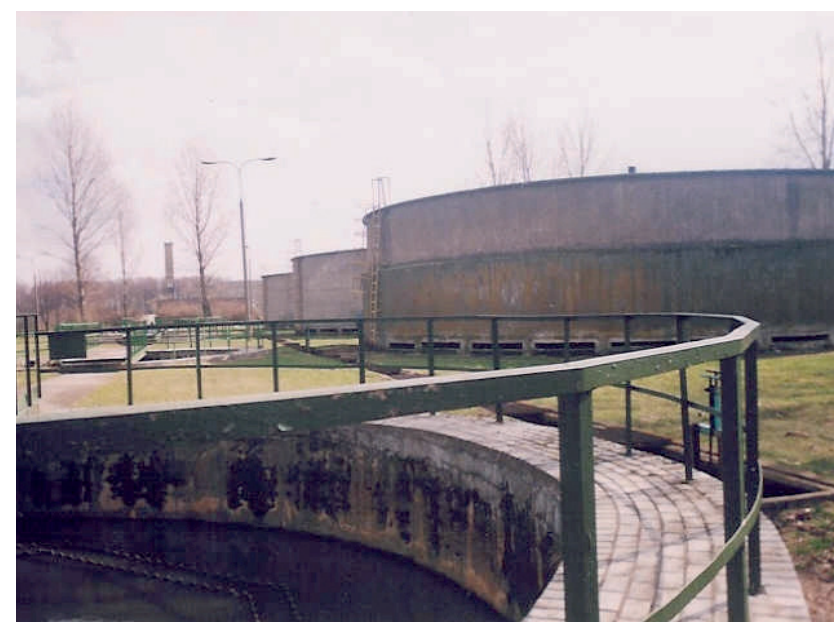

Rys. 11.6. Fragment osadnika wtórnego radialnego oraz złoża biologiczne Źródło: fot. autorki 
Zagrożenia pojawiające się w oczyszczalniach mogą być generowane przez wiele substancji o różnym stanie skupienia, w tym łatwo utleniających się. Do źródeł powstających zagrożeń zaliczamy między innymi: obecność w środowisku łatwopalnych gazów, kontakt z substancjami żrącymi i radioaktywnymi, mikroorganizmy i produkty ich metabolizmu, nagły wzrost ilości przepływających przez oczyszczalnię ścieków. Ponadto na niektórych instalacjach występuje niedomiar lub brak tlenu, który może prowadzić do utraty życia personelu. Dlatego też istnieje bezwzględna konieczność stosowania bezpiecznych technologii oczyszczania ścieków, maksymalnie zmniejszających ryzyko procesowe i zawodowe.

W wielu krajach na świecie stopień efektywności oczyszczania ścieków jest jeszcze niewystarczający $\mathrm{i}$ jest to jedna $z$ najistotniejszych przyczyn niezadowalającego stanu wód. W Polsce także istnieje obecnie pilna potrzeba wdrażania do praktyki przemysłowej nowoczesnych, wydajnych technologii oczyszczania wody i ścieków. Potrzeba ta wynika między innymi z wciąż zbyt małej wydajności procesów stosowanych do usuwania zanieczyszczeń zawartych w ściekach przemysłowych kierowanych do wód powierzchniowych. W przypadku tego rodzaju ścieków wskazane jest przede wszystkim wdrażanie zaawansowanych technologii utleniania, ale też podoczyszczanie lub oddzielne oczyszczanie poszczególnych strumieni silnie zanieczyszczonych ścieków, zanim zostaną zmieszane i dostarczone do oczyszczalni. Takie rozwiązania mogą stanowić skuteczną ochronę przed zatruciem osadu czynnego i obniżeniem jego sprawności w węzłach technologicznych oczyszczalni komunalnych.

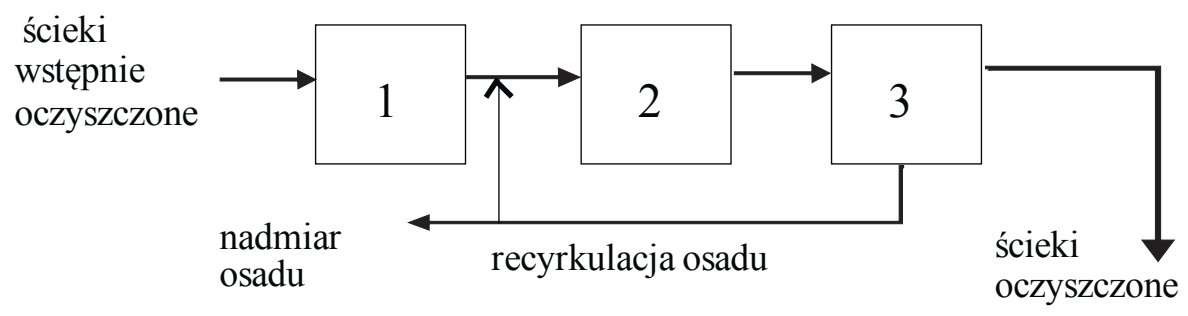

Rys. 11.7. Przykładowy schemat technologiczny oczyszczalni o zwiększonej efektywności

Oznaczenia: 1 - złoża biologiczne, 2 - komora kontaktowa z napowietrzaniem, 3 - osadnik wtórny

Źródło: opracowanie własne na podstawie Czempińska-Świtalska Z. i in., Gospodarka wodno-ściekowa, PWSOŚ, Radom 1998, s. 41 
W ostatnich latach priorytetem w zakresie technologii oczyszczania ścieków w krajach Unii Europejskiej, w tym także w Polsce, stało się wdrażanie technologii podwyższonego usuwania biogenów ze ścieków. Stosuje się je w oczyszczalniach o wysoko efektywnych technologiach oczyszczania (głównie biologicznych, a także chemicznych) umożliwiających zwiększoną redukcję związków azotu i fosforu. Przykładowy schemat oczyszczania ścieków z zastosowaniem tej technologii przedstawiono na rysunku 11.7.

Od kilkudziesięciu lat do oczyszczania oraz doczyszczania ścieków (jako trzeci stopień oczyszczania) z powodzeniem stosuje się oczyszczalnie korzeniowe (roślinne) z udziałem roślin wodnych (np. trzciny). W metodzie tej wykorzystuje się mikroorganizmy rozwijające się na korzeniach i łodygach roślin. Proces zachodzi w płytkich stawach lub złożach obsadzonych roślinami wodnymi, co przedstawiono na rysunku 11.8.

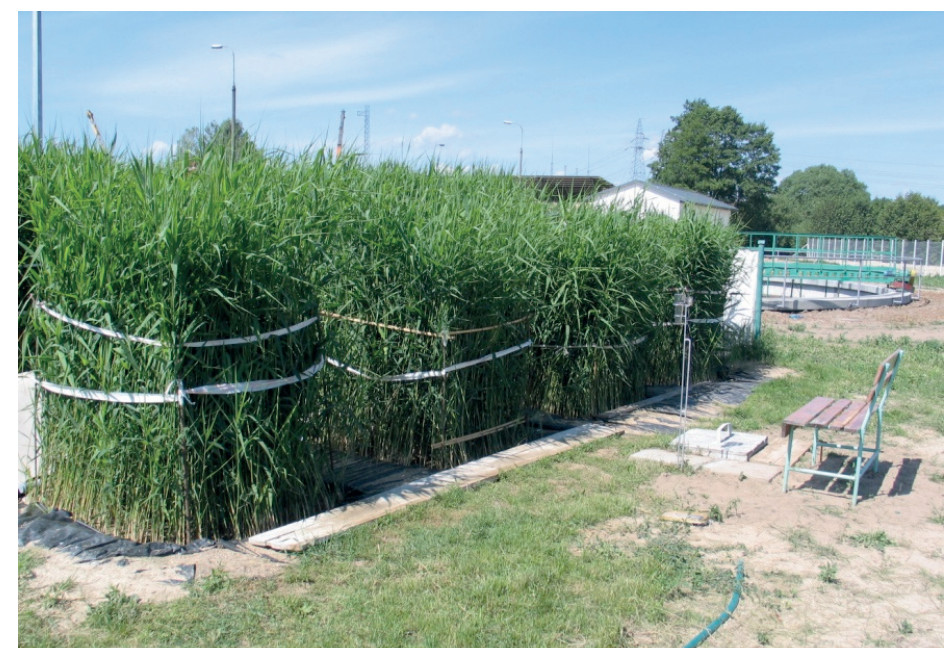

Rys. 11.8. Oczyszczalnia roślinna z filtrem trzcinowym jako trzeci stopień oczyszczania ścieków Źródło: fot. autorki

Coraz częściej do oczyszczania ścieków stosuje się też bioreaktory membranowe, które pozwalają na rozwiązanie wielu problemów towarzyszących konwencjonalnym metodom w tym zakresie. Odpowiednio dobrane membrany mogą stanowić bardzo skuteczną barierę dla zanieczyszczeń, nawet bez konieczności wprowadzania reagentów 
chemicznych. Główne zalety tych reaktorów w porównaniu do konwencjonalnych biologicznych metod oczyszczania są następujące:

- pozwalają na całkowite usunięcie ze ścieków zawiesin, także biologicznych;

- umożliwiają dezynfekcję dzięki usunięciu bakterii i wirusów;

- instalacja ma mniejsze rozmiary;

- odpadowy koncentrat zawiera tylko zanieczyszczenia występujące pierwotnie w ściekach;

- można dopasowywać wydajność reaktora membranowego do zapotrzebowania;

- uzyskuje się większe rozmiary biomasy w reaktorze, co podwyższa sprawność procesu.

W technologii oczyszczania ścieków bioreaktory membranowe są stosowane głównie do usuwania azotanów. Coraz częściej wykorzystuje się także połączenie klasycznego procesu osadu czynnego z membranową separacją ścieków oczyszczonych. Komora osadu czynnego jest zblokowana z membranowym modułem, który oddziela zawiesinę biomasy od biologicznie oczyszczonych ścieków.

\subsection{Oczyszczanie ścieków na terenach niezurbanizowanych}

Unieszkodliwianie ścieków odprowadzanych z pojedynczych domów lub niewielkich ich zgrupowań na terenach niezurbanizowanych może być realizowane według trzech podstawowych wariantów: przydomowej oczyszczalni ścieków, kanalizacji bezodpływowej lub zbiorczego systemu kanalizacyjnego. Na obszarach kraju o niewystarczająco rozwiniętej infrastrukturze kanalizacyjnej najczęściej mieszkańcy korzystają z przydomowych systemów do odprowadzania ścieków lub zbiorników bezodpływowych.

Oczyszczalnie przydomowe pozwalają oczyścić ścieki pochodzące z jednego lub kilku gospodarstw domowych. Ścieki oczyszczane są bezpośrednio w gospodarstwie. Należy uzyskać wymagany stopień oczyszczania związany z odprowadzaniem ścieków do wody lub do ziemi. Zastosowanie mają oddzielne oczyszczalnie dla każdego domu lub też oczyszczalnie budowane dla kilku domów położonych blisko siebie. Warunkiem prawidłowej eksploatacji takiej oczyszczalni jest umiejętna 
obsługa zespołu urządzeń, która polega między innymi na kontroli składu odpływu, odpowiedniej regulacji natlenienia i uzupełnieniu kultur mikroorganizmów, usuwaniu osadu i kożucha z osadnika. Ścieki pochodzące z gospodarstwa domowego mogą zostać odprowadzone do ziemi tylko w granicach gruntu należącego do jego właściciela.

Kanalizacja bezodpływowa, potocznie nazywana szambami, obejmuje gromadzenie ścieków w szczelnych zbiornikach, a następnie ich wywóz środkami transportu asenizacyjnego do oczyszczalni ścieków w najbliższej jednostce osadniczej. Rozwiązanie to ma wiele wad. Po pierwsze, nie każda oczyszczalnia ma możliwość przyjęcia ścieków tak mocno skoncentrowanych jak ścieki pochodzące z szamb ze względu na stosowane w danej oczyszczalni technologie. Istnieją w Polsce oczyszczalnie, które nie mają punktu zlewnego i nie są w stanie przyjmować przywożonych ścieków. Znaczną uciążliwością może być duża częstotliwość wywozu ścieków, z czym wiążą się także podwyższone koszty eksploatacji, szczególnie wtedy, gdy transport ścieków odbywa się na znacznych odległościach. Istotną wadą jest także uciążliwość pracy wozu asenizacyjnego dla otoczenia.

W przypadku zwartej zabudowy danego obszaru wiejskiego ze względu na koszt sieci kanalizacyjnej uzasadniona ekonomicznie może się okazać budowa zbiorczego systemu kanalizacyjnego dla całej jednostki osadniczej, obejmująca sieć kanalizacyjną z ewentualnymi pompowniami oraz zbiorczą oczyszczalnią ścieków. Oczyszczalnie zbiorcze pozwalają oczyścić ścieki pochodzące z wielu wsi, a ścieki odprowadzane są wspólną siecią kanalizacyjną. Oczyszczalnie lokalne pozwalają oczyścić ścieki pochodzące z kilku lub kilkunastu gospodarstw domowych, odprowadzane wspólną siecią kanalizacyjną do tej oczyszczalni.

Tabela 11.1. Instalacje do gromadzenia nieczystości ciekłych w Polsce w latach 2012-2014 (w szt.)

\begin{tabular}{|c|c|c|c|}
\hline Rok & $\begin{array}{c}\text { Zbiorniki } \\
\text { bezodpływowe }\end{array}$ & $\begin{array}{c}\text { Oczyszczalnie } \\
\text { przydomowe }\end{array}$ & Stacje zlewne \\
\hline 2012 & 2318140 & 126164 & 2234 \\
\hline 2013 & 2256572 & 154944 & 2267 \\
\hline 2014 & 2192116 & 181295 & 2305 \\
\hline
\end{tabular}

Źródło: opracowanie własne na podstawie GUS².

2 http://stat.gov.pl/obszary-tematyczne/infrastruktura-komunalna-nieruchomosci/ nieruchomosci-budynki-infrastruktura-komunalna/infrastruktura-komunalna-w-2014-r-,3,12.html. (data dostępu: 30 listopada 2015 roku) 
Według danych GUS w 2014 roku w Polsce funkcjonowało 2373 tys. przydomowych systemów do odprowadzania ścieków, z czego około 92\% stanowiły zbiorniki bezodpływowe. Od kilku lat obserwowany jest systematyczny spadek liczby zbiorników bezodpływowych, zwiększa się natomiast liczba przydomowych oczyszczalni ścieków. Liczba zbiorników bezodpływowych spadła w 2014 roku o około 3\% w porównaniu z 2013 rokiem, natomiast liczba przydomowych oczyszczalni ścieków wzrosła o 17,0\%. W 2014 roku około 84\% wszystkich przydomowych urządzeń do odprowadzania nieczystości zlokalizowanych było na obszarach wiejskich, w tym około $91 \%$ ogólnej liczby przydomowych oczyszczalni ścieków.

Ze względów środowiskowych odprowadzenie ścieków sieciami kanalizacyjnymi do oczyszczalni jest dobrym sposobem zagospodarowania ścieków na terenach niezurbanizowanych. Jednakże w przypadku każdej realizowanej inwestycji należy przeprowadzić rachunek ekonomiczny ochrony środowiska i wybrać wariant najodpowiedniejszy, biorąc pod uwagę zarówno aspekty ekonomiczne, ekologiczne, jak i społeczne. Jeśli skalkulowany koszt budowy sieci kanalizacyjnej na danym terenie okaże się zbyt wysoki, to należy rozważyć możliwość zastosowania innego rozwiązania, bardziej korzystnego ekonomicznie, jak na przykład budowa przydomowych oczyszczalni lub szamb.

\subsection{Metody przeróbki osadów ściekowych}

Podczas wielu procesów oczyszczania ścieków powstają osady ściekowe i produkty uboczne: skratki, piasek, osad wstępny, tłuszcze oraz osad wtórny. Przez osady ściekowe należy rozumieć pochodzące z oczyszczalni ścieków osady z komór fermentacyjnych oraz innych instalacji służących do oczyszczania ścieków. Osady ściekowe są mieszaniną różnorodnych mikroorganizmów żywych i martwych oraz składników organicznych i mineralnych. llość i skład osadów uzależnione są od jakości ścieków dopływających do oczyszczalni oraz sposobu i stopnia ich oczyszczania. Ze względu na toksyczność osady ściekowe stanowią potencjalne zagrożenie dla zdrowia i życia ludzi oraz zwierząt, dlatego należy je poddać utylizacji, zachowując przy tym szczególną ostrożność. Skratki, piasek i tłuszcze są najczęściej wywożone z oczyszczalni ścieków na składowisko odpadów.

Proces przeróbki osadów ściekowych składa się z operacji jednostkowych, tworzących ciąg technologiczny dostosowany do formy ich końcowego zagospodarowania. W wyniku przeróbki osadów powinny 
nastąpić przede wszystkim: zmniejszenie ich objętości (zagęszczanie), odwodnienie, stabilizacja tlenowa i beztlenowa, higienizacja, detoksykacja i w końcowym etapie - unieszkodliwianie.

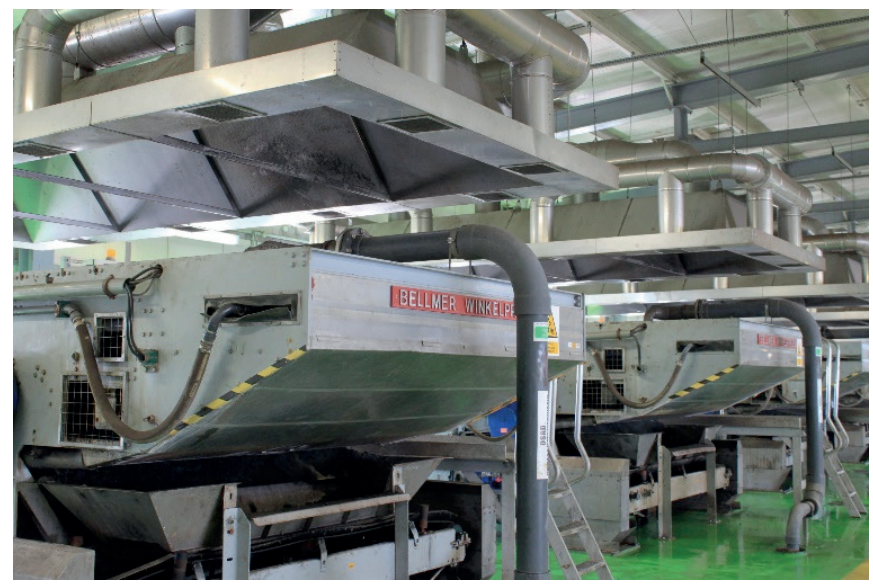

Rys. 11.9. Instalacja odwadniania osadów ściekowych

Źródło: Archiwum Grupowej Oczyszczalni Ścieków w Łodzi Sp. z o. o.

Rysunek 11.9. przedstawia zdjęcie instalacji odwadniania osadów ściekowych funkcjonującej w GOŚK w Łodzi. Wysoka skuteczność mechanicznego zagęszczania oraz odwadniania osadów ma duże znaczenie dla energochłonności dalszych procesów przeróbki, w szczególności procesu suszenia. Obecnie stosowanych jest wiele innowacyjnych i efektywnych metod odwadniania osadów. Jeśli w oczyszczalni funkcjonują wydzielone komory fermentacyjne, wówczas korzystne jest zastosowanie procesu hydrolizy termicznej przed tymi komorami i wykorzystanie nadwyżki powstałego biogazu. Polecana jest także kofermentacja osadów ściekowych z odpadami ulegającymi biodegradacji. W razie braku komór fermentacyjnych wskazane jest odwadnianie osadów, przeprowadzone z wysoką skutecznością przed procesem ich suszenia. Istotne jest również usunięcie substancji biogennych z odcieków z odwadniania osadów, zamiast zawracania ich do oczyszczania łącznie z dopływającymi ściekami, ponieważ odcieki zawierają znaczne ładunki zanieczyszczeń.

Unieszkodliwianie osadów ściekowych polega na ich usuwaniu lub ograniczeniu ich uciążliwości poprzez: przyrodnicze lub rolnicze wykorzystanie, spalanie, pirolizę (odgazowanie), utlenianie na mokro, neutralizację chemiczną, chlorowanie lub inne metody. 
Suszenie oraz spalanie osadów jest metodą bardzo energochłonną, a przez to kosztowną. Przed spaleniem należy osad wysuszyć, aby zawierał około $80 \%$ suchej masy. Zgazowanie polega na przekształceniu w wysokich temperaturach węgla zawartego w osadach w paliwo gazowe. Odbywa się różnymi metodami oraz w różnych warunkach ciśnienia i temperatury, ale przeważnie z udziałem tlenu i pary wodnej.

Za wykorzystanie osadów do celów rolniczych uważa się zastosowanie osadów ściekowych do uprawy wszystkich płodów rolnych wprowadzanych do obrotu handlowego, w tym także przeznaczonych do produkcji pasz. Istotne jest jednak, aby osady te nie zawierały metali ciężkich, substancji toksycznych i organizmów patogennych. Nieco mniejsze wymagania stawia się osadom wykorzystywanym do rekultywacji terenów zdegradowanych oraz do nawożenia roślin, ale tylko tych, które nie są przeznaczone do celów spożywczych.

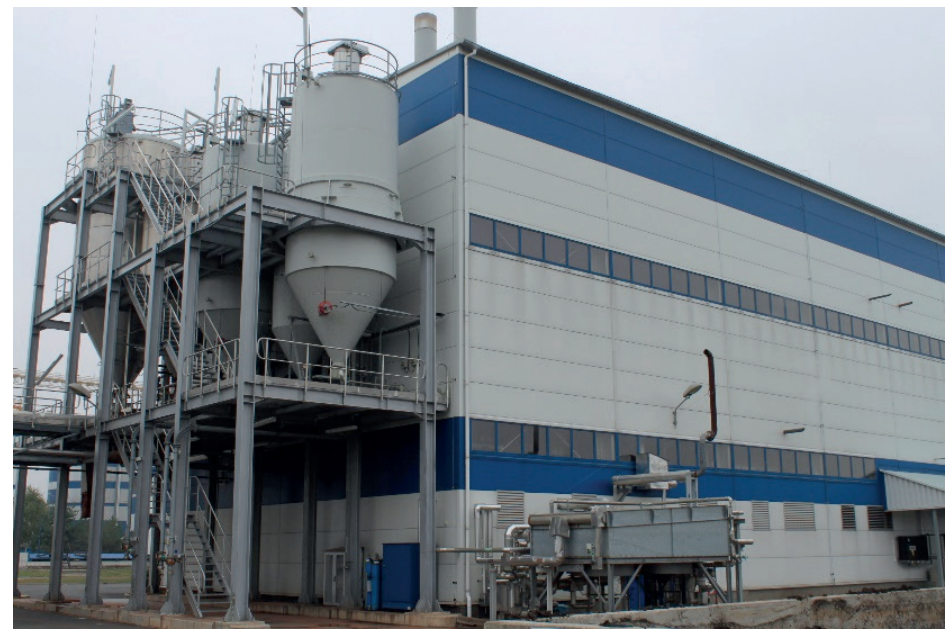

Rys. 11.10. Spalarnia osadów ściekowych

Źródło: Archiwum Grupowej Oczyszczalni Ścieków w Łodzi Sp. z o. o.

Zagospodarowanie osadów ściekowych jest obecnie istotnym problemem o charakterze społecznym, środowiskowym, technicznym i ekonomicznym w skali globalnej, ponieważ ich masa wzrasta z każdym rokiem. W naszym kraju ich ilość także wzrasta, a związane jest to głównie z realizacją Krajowego Programu Oczyszczania Ścieków Komunalnych. Dotychczas osady ściekowe zagospodarowywano głównie przez ich składowanie, stosowano do rekultywacji terenów i w rolnictwie, do uprawy roślin 
przeznaczonych do produkcji kompostu oraz poprzez tzw. czasowe magazynowanie. Jednakże w wielu dużych aglomeracjach rozpoczęto termiczne przekształcanie osadów ściekowych. Innowacyjną instalację spalania osadów ściekowych zastosowano na przykład w GOŚ w Łodzi (rys. 11.10).

Podsumowując rozważania na temat przeróbki osadów ściekowych, warto przeanalizować aktualne dane statystyczne $w$ tym zakresie. W ciągu całego 2014 roku w oczyszczalniach ścieków komunalnych w Polsce wytworzono 556 tys. ton suchej masy osadów ściekowych. Zostały one zagospodarowane przede wszystkim w procesach biologicznych i rolniczych, a także przekształcone termicznie (rys. 11.1). Na koniec roku 2014 zgromadzono także na terenie oczyszczalni 226 tys. ton osadów.

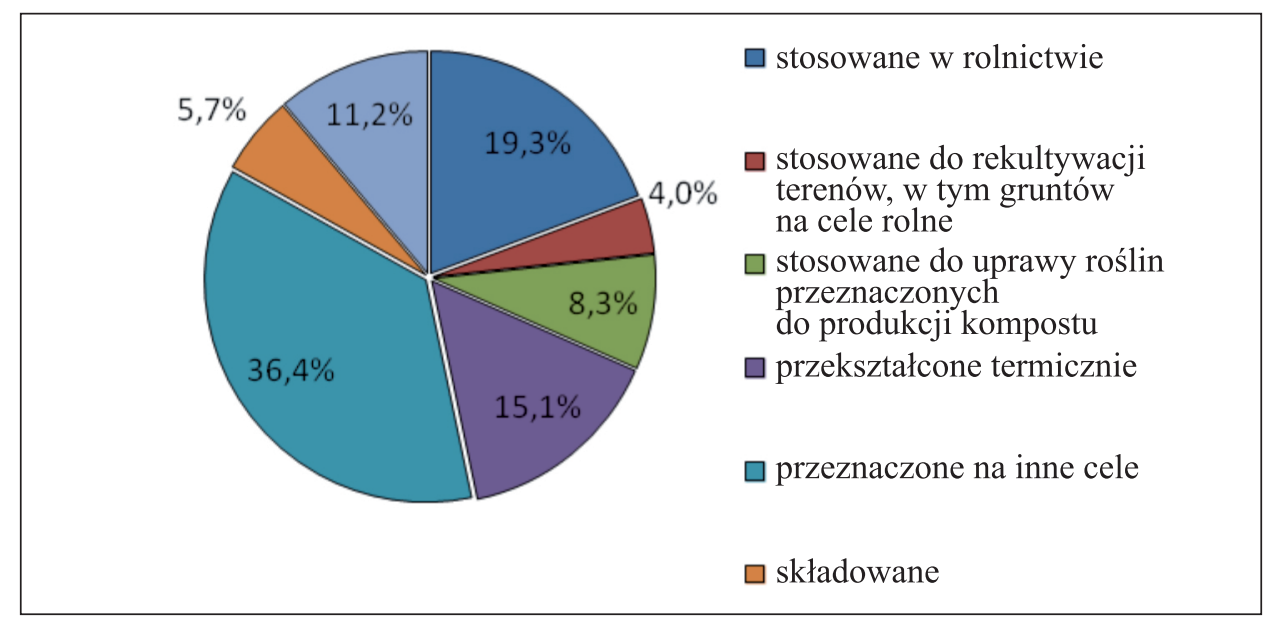

Rys. 11.11. Postępowanie z osadami z komunalnych oczyszczalni ścieków w Polsce w 2014 r.

Źródło: opracowanie własne na podstawie danych GUS ${ }^{3}$

\section{Literatura}

Apolinarski M., Perchulć M., Wąsowski J., Procesy jednostkowe w technologii wody, Oficyna Wydawnicza Politechniki Warszawskiej, Warszawa 2008.

Bartkiewicz B., Oczyszczanie ścieków przemysłowych, Wydawnictwo Naukowe PWN, Warszawa 2002.

3 Ochrona środowiska 2015, GUS, Warszawa 2015, s. 525. 
Bień J., Neczaj E., Worwąg M., Grosser A., Nowak D., Milczarek M., Janik M., Kierunki zagospodarowania osadów w Polsce po roku 2013, „Inżynieria i Ochrona Środowiska", t. 14, nr 4/2011, s. 375-384.

Chełmicki W., Woda. Zasoby, degradacja. ochrona, Wydawnictwo Naukowe PWN, Warszawa 2001.

Chrobot P., Potencjał technologii membranowych w branży wod-kan, „Wodociągi i Kanalizacja", nr 10(140)/2015, s. 52-56.

Czempińska-Świtalska Z., Góralczyk M., Góralczyk R., Gospodarka wodno-ściekowa, PWSOŚ, Radom 1998.

Dyrektywa Rady 91/271/EWG z dnia 21 maja 1991 r. dotycząca oczyszczania ścieków komunalnych (Dz.Urz. UE L 135/40).

Europejski Trybunał Obrachunkowy, Wsparcie UE na rzecz oczyszczalni ścieków komunalnych w dorzeczu Dunaju: konieczne są dalsze działania, aby pomóc państwom członkowskim w realizacji celów polityki UE w zakresie gospodarowania ściekami, „Unia Europejska”, wydanie specjalne 02/2015, Luksemburg 2015.

Gromiec M., Słowik N. (red.), Zastosowanie nowych technologii w sektorze ochrony środowiska, NFOśiGW, Warszawa 2006.

Gromiec M., Efektywność energetyczna systemów wodno-ściekowych, „Przegląd Komunalny", nr 11/2015, s. 79-81.

Hangen M., Oczyszczanie ścieków: procesy biologiczne i chemiczne, Wydawnictwo Politechniki Świętokrzyskiej, Kielce 2000.

Heidrich Z., Witkowski A., Urządzenia do oczyszczania ścieków, Wydawnictwo Seidel-Przywecki, Warszawa 2005.

Heidrich Z., Stańko G., Leksykon przydomowych oczyszczalni ścieków, Wydawnictwo Seidel-Przywecki, Warszawa 2007.

Infrastruktura komunalna w 2014 r., GUS, Warszawa 2015.

Małecki Z., Zagrożenia, zanieczyszczenia i ochrona wód: wybrane zagadnienia inżynierii ekologicznej, Polskie Towarzystwo Inżynierii Ekologicznej, Kalisz 2005.

Mięso R., Metody zagospodarowania osadów ściekowych, [w:] M. Banaś (red.), Ochrona i inżynieria środowiska - Zrównoważony rozwój, Monografia, Zeszyt Nr 37, Wydział Inżynierii Mechanicznej i Robotyki AGH w Krakowie, Wydawnictwo AGH, Kraków 2008, s. 119-131.

Obarska-Pempkowiak H., Hydrofitowe oczyszczanie wód i ścieków, PWN, Warszawa 2010.

Ochrona środowiska 2015, GUS, Warszawa 2015.

Pisarczyk St., Elementy budownictwa ochrony środowiska, Oficyna Wydawnicza Politechniki Warszawskiej, Warszawa 2008.

Rozporządzenie Ministra Środowiska z dnia 24 lipca 2006 r. w sprawie warunków, jakie należy spełnić przy wprowadzaniu ścieków do wód czy ziemi oraz w sprawie substancji szczególnie szkodliwych dla środowiska wodnego.

Sikora J., Biotechnologia ścieków, PWN, Warszawa 2010. 
Szpindor A., Zaopatrzenie w wodę i kanalizacja wsi, Wydawnictwo ARKADY, Warszawa 1998.

Środa K., Kijko-Kleczkowska A., Otwinowski K., Termiczne unieszkodliwianie osadów ściekowych, „Inżynieria Ekologiczna”, nr 28/2012, s. 67-81.

Środa K., Kijko-Kleczkowska A., Otwinowski K., Metody utylizacji osadów ściekowych, "Archiwum Gospodarki Odpadami i Ochrony Środowiska" 2013, Vol. 15, nr 2, s. 33-49.

Zarzycki R., Imbierowicz M., Stelmachowski M., Wprowadzenie do inżynierii i ochrony środowiska, t. 1: Ochrona środowiska naturalnego, WNT, Warszawa 2007.

Żelazo J., Popek Z., Podstawy renaturyzacji rzek, Wydawnictwo SGGW, Warszawa 2002.

Żelazo J., Renaturyzacja rzek i dolin. Infrastruktura i ekologia terenów wiejskich: Komisja technicznej infrastruktury wsi Nr 4/1/2006, Polska Akademia Nauk, Oddział w Krakowie.

http://www.instsani.webd.pl/metooczy.htm.

http://archiwum.ekoportal.gov.pl/prawo_dokumenty_strategiczne/ochrona_srodowiska_w_polsce_zagadnienia/Woda/zasady_ochrony_wod.html.

http://stat.gov.pl/obszary-tematyczne/infrastruktura-komunälna-nieruchomosci/ nieruchomosci-budynki-infrastruktura-komunalna/infrastruktura-komunalna-w-2014-r-,3,12.html. 


\section{Rozdział 12}

\section{Inżynieria środowiska a sektor energetyki}

\subsection{Technologie środowiskowe w energetyce}

Postęp naukowy w inżynierii środowiska fundamentalnie przyczynił się w ostatnich latach do rozwoju wielu technologii i procesów przyjaznych środowisku w sektorze energetycznym. Przede wszystkim zaprojektowano i wdrożono wiele inżynierskich rozwiązań, które pozwalają na produkcję energii elektrycznej i cieplnej z odnawialnych źródeł energii, w tym także w mikroinstalacjach. Ponadto osiągnięcia w dziedzinie inżynierii środowiska mają istotny wpływ na rozwój czystszych technologii wytwarzania w energetyce konwencjonalnej, w tym wykorzystania biomasy w procesach współspalania.

Środowiskowe „zielone" technologie odgrywają istotną rolę głównie w poszukiwaniu nowych, ekologicznych źródeł energii. Ograniczoność zasobów energetycznych nieodnawialnych, ale przede wszystkim restrykcyjna unijna polityka klimatyczno-energetyczna znacząco przyczyniły się do intensywnego rozwoju technologii pozyskiwania energii z odnawialnych źródeł energii (OZE), szczególnie w krajach UE.

Energia ze źródeł odnawialnych oznacza energię pochodzącą z naturalnych powtarzających się procesów przyrodniczych, pozyskiwaną z odnawialnych niekopalnych źródeł energii. Do tych źródeł zaliczamy: energię wody, wiatru, promieniowania słonecznego, geotermalną, fal, prądów i pływów morskich oraz energię wytwarzaną z biopaliw stałych, biogazu i biopaliw ciekłych, a także energię otaczającego środowiska wykorzystywaną przez pompy ciepła. Zasoby OZE można traktować jako niewyczerpalne, mogą więc one stanowić alternatywę dla paliw kopalnych. Dodatkowo wykorzystywanie OZE w znacznym stopniu zmniejsza szkodliwe oddziaływanie energetyki na środowisko naturalne, głównie poprzez ograniczenie emisji szkodliwych substancji.

Dane zawarte w tabeli 12.1 pokazują, że struktura pozyskania energii ze źródeł odnawialnych dla Polski istotnie różni się od struktury pozyskania energii ze źródeł odnawialnych dla Unii Europejskiej, przede wszystkim z powodu charakterystycznych dla naszego kraju warunków 
geograficznych i możliwych do zagospodarowania zasobów. Energia pozyskiwana ze źródeł odnawialnych w Polsce pochodzi w przeważającym stopniu z biopaliw stałych (80\%), biopaliw ciekłych, z energii wiatru, energii wody i biogazu.

Tabela 12.1. Porównanie pozyskania energii ze źródeł odnawialnych według nośników w krajach UE-28 oraz w Polsce w 2013 r. (w \%)

\begin{tabular}{|l|c|c|}
\hline \multicolumn{1}{|c|}{ Rodzaj nośnika } & UE-28 & Polska \\
\hline Biopaliwa stałe & 45,83 & 80,03 \\
Energia wody & 16,61 & 2,46 \\
Energia wiatru & 10,53 & 6,05 \\
Biogaz & 7,05 & 2,12 \\
Biopaliwa ciekłe & 6,71 & 8,20 \\
Energia słoneczna & 5,54 & 0,18 \\
Odpady komunalne & 4,64 & 0,42 \\
Energia geotermalna & 3,08 & 0,22 \\
Energia fal oceanu & 0,02 & - \\
Pompy ciepła & - & 0,33 \\
\hline
\end{tabular}

Źródło: opracowanie własne na podstawie danych GUS'1.

Pomimo panujących obecnie wielu sprzecznych opinii co do rentowności oraz wpływu na zdrowie człowieka i przyrodę elektrowni wiatrowych technologie te są stosunkowo szeroko stosowane w krajach UE. Czyste ekologicznie źródło wykorzystuje także energia słoneczna. Dzięki niej można uzyskać zarówno energię cieplną (baterie i kolektory słoneczne), jak i elektryczną (za pomocą ogniw fotowoltaicznych). Innowacyjnym rozwiązaniem w tym obszarze są oparte na nanotechnologii ogniwa słoneczne, które wyróżniają się niską ceną produkowanej energii elektrycznej. Kolejnym bardzo popularnym obecnie odnawialnym źródłem energii i stosunkowo łatwo dostępną technologią pozyskiwania energii jest biomasa, która, biorąc pod uwagę krajowy potencjał OZE, może odgrywać szczególną rolę także w przyszłości. W perspektywie 2020 roku

1 Energia ze źródeł odnawialnych w 2013 r., GUS, Departament Produkcji, Warszawa 2014, s. 2 oraz Energia 2015, GUS, Departament Produkcji, Warszawa 2015, s. 15. 
przewiduje się bowiem znaczące wsparcie dla rozwoju wysokosprawnych instalacji (w szczególności małych) do spalania biomasy, a także upraw energetycznych na glebach najniższych kategorii. Wiedza inżynieryjna i technologie środowiskowe umożliwiają pozyskiwanie energii również z zasobów wodnych (elektrownie wodne), a także z bardzo cennych źródeł geotermalnych. Rozwój wszystkich wymienionych powyżej technologii OZE powinien przyczynić się dalszego zwiększenia ich udziału w krajowym bilansie energetycznym. Według danych GUS udział energii z OZE w końcowym zużyciu energii brutto w 2013 roku wyniósł w krajach UE $15 \%$, natomiast w Polsce $11,3 \%$.

Przedstawiając problematykę technologii prośrodowiskowych w energetyce, warto wspomnieć także o inteligentnych sieciach energetycznych (ISE). Są to systemy energetyczne integrujące działania wszystkich uczestników procesów generacji, przesyłu, dystrybucji i użytkowania, w celu dostarczania energii w sposób niezawodny, bezpieczny i ekonomiczny, z uwzględnieniem wymogów ochrony środowiska. Inteligentne liczniki zużycia prądu umożliwiają wszystkim odbiorcom zarządzanie zużyciem energii poprzez dokładny monitoring w czasie rzeczywistym. Tego typu rozwiązania pozwalają na znaczące zwiększenie efektywności energetycznej, ponieważ w przeciwieństwie do tradycyjnego, jednokierunkowego przesyłu energii umożliwiają dwukierunkowy przesył prądu, zarówno na linii zakład energetyczny-klient, jak i na linii klient-klient. Oznacza to, że gospodarstwo domowe (jako producent) będzie mogło odsprzedać nadwyżkę wyprodukowanej energii zakładowi energetycznemu lub sąsiadom. Można więc stwierdzić, że ISE zapewnia zrównoważone, nisko awaryjne oraz bezpieczne działanie sieci energetycznej i dostaw energii, promuje postawy związane z odpowiedzialnym korzystaniem z energii przez konsumentów, aktywizuje odbiorców energii i angażuje ich również w proces wytwarzania energii (prosumpcja), przyczynia się do zwiększenia konkurencyjności na rynku energetycznym, a także stwarza lepsze warunki do wzrostu udziału energii odnawialnej w krajowym bilansie energetycznym, a w efekcie ogranicza wpływ procesów energetycznych na środowisko.

\subsection{Inżynieria środowiska a energetyka konwencjonalna}

Obecnie paliwa konwencjonalne wykorzystywane są do produkcji energii:

- cieplnej - z wykorzystaniem kotłowni, ciepłowni, elektrowni jądrowych; 
- elektrycznej - w elektrowniach węglowych i jądrowych;

- cieplnej i elektrycznej - w elektrociepłowniach;

- mechanicznej, np. do napędzania silników.

W klasycznych elektrowniach wykorzystujących paliwa konwencjonalne zachodzą przede wszystkim procesy spalania, podczas których uwalniania jest energia cieplna. Energia tę wykorzystuje się do produkcji pary wodnej, która następnie $w$ turbinach zamieniana jest na energię elektryczną. Całkowita sprawność takiego procesu wytwarzania energii elektrycznej zazwyczaj nie przekracza $60 \%$.

Według danych GUS w 2014 roku w Polsce najwięcej energii cieplnej na cele grzewcze wyprodukowano z wykorzystaniem paliwa stałego $(63,9 \%)$, w tym węgla, który stanowił $58,3 \%$ i biomasy $-5,6 \%$. W dalszej kolejności na cele grzewcze wykorzystano gaz - w 33,7\% oraz olej $-2,4 \%$. Na koniec 2014 roku w Polsce pracowało 24037 kotłowni, z liczbą 4500 zainstalowanych kotłów cieplnych wykorzystujących węgiel, 9457 - gaz ziemny, 2249 - olej opałowy lekki oraz 483 - biomasę leśną. Podstawowym paliwem w Polsce jest więc obecnie węgiel i dlatego konieczne jest wdrażanie nowoczesnych technologii wykorzystania tego surowca energetycznego, przyjaznych dla środowiska naturalnego.

Istnieje technologia skojarzonego wytwarzania energii elektrycznej i ciepła, zwana kogeneracją (CHP), w której energia pierwotna zawarta w paliwie jest w jednym procesie technologicznym, w tym samym urządzeniu wytwórczym zamieniana na dwa produkty: energię elektryczną i ciepło. Sprawność ogólna tego procesu w porównaniu z rozdzielonym wytwarzaniem energii elektrycznej i ciepła jest dużo wyższa, przez co zapewnia wiele korzyści finansowych i środowiskowych, jak na przykład obniżenie kosztów zużycia energii pierwotnej, niższe koszty inwestycji w urządzenia towarzyszące, ograniczenie emisji szkodliwych substancji, unikanie strat sieciowych czy zmniejszenie emisji tlenków siarki w przypadku wykorzystania gazu ziemnego zamiast węgla kamiennego jako paliwa. Ponadto efektywne użytkowanie energii w tym sposobie wytwarzanie energii może wpłynąć pozytywnie na bezpieczeństwo dostaw energii i konkurencyjność Unii Europejskiej. Dlatego też promowanie wysokosprawnej kogeneracji na podstawie zapotrzebowania na ciepło użytkowe stanowi jeden z priorytetów Wspólnoty Europejskiej zarówno w poprzedniej perspektywie finansowania, jak i w latach 2014-2020. 
Należy podkreślić, że obecnie paliwa kopalne stanowią podstawę energetyki i przemysłu w wielu krajach świata, także w Polsce i według licznych scenariuszy będą one ważnym surowcem dla energetyki również w przyszłości. W związku z tym podejmowane są wysiłki wykorzystania osiągnięć inżynierii środowiska w celu ograniczania negatywnych skutków środowiskowych wynikających ze stosowania surowców konwencjonalnych. Proponowane rozwiązania inżynieryjne dotyczą między innymi wydobycia i przygotowania surowców (w zakresie tzw. uszlachetniania) oraz bardziej efektywnych i mniej emisyjnych technologii spalania. Dobrym przykładem może być tutaj technologia zgazowania węgla w złożu, czyli proces jego wysokotemperaturowej konwersji do gazu z użyciem czynnika zgazowującego. W wyniku zgazowania powstaje gaz syntezowy, którego głównymi składnikami są $\mathrm{H}_{2}, \mathrm{CO}, \mathrm{CO}_{2}$ oraz $\mathrm{CH}_{4}$. Gaz syntezowy jest cennym surowcem chemicznym oraz może być wykorzystywany jako paliwo.

Najczęściej jednak stosowanymi rozwiązaniami ograniczania negatywnych skutków zanieczyszczenia środowiska przez energetykę są tzw. metody końca rury, polegające na usuwaniu zanieczyszczeń gazowych i pyłowych wydobywających się z komina elektrowni. Metody te powinny być wdrażane po wyczerpaniu wszystkich innych możliwości zapobiegania uciążliwym emisjom.

Do takich działań można zaliczyć między innymi: wzbogacanie paliw, stosowanie odpylaczy o większej skuteczności, budowę wysokich kominów i koncentrację spalin w jednym kominie, odsiarczanie spalin, utylizację odpadów paleniskowych, wdrażanie nowych technologii energetycznych (jak np. kotły fluidalne czy zgazowanie węgla). Dobre efekty przynosi także jednoczesne realizowanie różnych przedsięwzięć, jak na przykład odsiarczanie paliw i odsiarczanie spalin.

W ostatnich latach propagowana jest także technologia wychwytywania i składowania dwutlenku węgla pochodzącego ze spalania paliw kopalnych głęboko w strukturach geologicznych. Jednak wielu ekspertów uważa tę technologię za zbyt kosztowną i energochłonną. Trudno jest też obecnie przewidzieć, jak po wielu latach zachowa się składowany pod ziemią dwutlenek węgla i jakie tego będą skutki.

Z wszystkich paliw konwencjonalnych względnie najmniejsze negatywne oddziaływanie na środowisko ma gaz ziemny. Jego spalanie nie przyczynia się do emisji pyłów i tlenków siarki, natomiast emisja gazów cieplarnianych jest dużo niższa niż w przypadku węgla czy ropy naftowej. Gaz ziemny nazywany jest często paliwem XXI wieku, a jego znaczenie 
na rynkach światowych rośnie. Szanse dla Polski, zarówno w wymiarze gospodarczym, jak i geopolitycznym stwarza produkcja gazu ziemnego ze źródeł niekonwencjonalnych, w tym z łupków. Niektóre wyniki badań wskazują jednak, że wydobycie gazu z łupków może się wiązać z negatywnym oddziaływaniem na środowisko, szczególnie $w$ odniesieniu do wód. W związku z tym rozwija się nowy i ważny z punktu widzenia gospodarczego i środowiskowego obszar badań w zakresie inżynierii środowiska.

Podsumowując, ze względu na problem emisji wielu szkodliwych zanieczyszczeń z energetyki jednym z kluczowych rozwiązań powinno być kontynuowanie prac badawczo-rozwojowych nad czystymi technologiami węglowymi w Polsce. Efektywniejsze wykorzystanie osiągnięć inżynierii środowiska w tym zakresie, zgodnych z ideą zrównoważonego rozwoju może zmniejszyć emisję szkodliwych gazów i pyłów z energetycznego spalania węgla w sposób ekonomicznie uzasadniony. Wykorzystując posiadany potencjał energetyki konwencjonalnej Polska ma dużą szansę stać się światowym liderem w dziedzinie rozwoju oraz szerokiego wykorzystania technologii czystego węgla.

\subsection{Inżynieria środowiska na rzecz gospodarki niskoemisyjnej}

Jednym z głównych założeń Narodowego Programu Rozwoju Gospodarki Niskoemisyjnej jest zapewnienie, zgodnie z koncepcją zrównoważonego rozwoju, korzyści ekonomicznych, społecznych i środowiskowych płynących z rozwoju gospodarki opartej przede wszystkim na tzw. czystych i niskoemisyjnych technologiach energetycznych. Rola inżynierii środowiska $w$ tym zakresie jest kluczowa, ponieważ poprzez rozwój niskoemisyjnych źródeł energii (w tym odnawialnych źródeł energii) przyczynia się do zmniejszenia emisji i energochłonności w procesach produkcyjnych, jak i w całej gospodarce. Jednocześnie wdrażanie innowacyjnych rozwiązań i technologii przyjaznych środowisku zwiększa efektywność energetyczną i poprawia efektywność gospodarowania surowcami, materiałami i odpadami.

Warto w tym miejscu posłużyć się przykładem nowoczesnego inteligentnego budynku, który poprzez zastosowanie wielu inżynieryjnych rozwiązań wpisuje się w koncepcję gospodarki niskoemisyjnej, niskoenergetycznej i energooszczędnej. W takich budynkach obecny jest system BMS, czyli scentralizowany system zarządzania budynkiem, odpowiedzialny za integrację, kontrolę i sprawne działanie w budynku wszystkich 
możliwych systemów, w tym ogrzewania. Wśród potencjalnych korzyści płynących z jego użytkowania można wskazać: zmniejszenie opłat za energię elektryczną oraz cieplną oraz pełny monitoring i analizę zużycia energii.

Osiągnięcia inżynierii środowiska widoczne są także w innych obszarach energetyki. Warto wspomnieć o elektrociepłowniach, które również stopniowo wdrażają nowe technologie skierowane na ograniczenie emisji szkodliwych substancji do atmosfery. Z powodzeniem wykorzystywane są takie technologie do produkcji energii, jak: klasyczne i gazowe pompy ciepła, ogniwa fotowoltaiczne czy kolektory słoneczne.

Jednak coraz bardziej znana staje się mikrokogeneracja, czyli mikroelektrociepłownia zasilana przez gaz ziemny, gaz płynny lub biogaz, która zapewnia efektywną i ekonomiczną produkcję energii. Jest systemem o niewielkich rozmiarach i cichej pracy, dzięki czemu można ją zainstalować w domach lub hotelach. System ten działa na bazie silnika spalinowego napędzanego gazem. Gaz w porównaniu do innych źródeł energii generuje stosunkowo niską emisję zanieczyszczeń, dlatego jest postrzegany jako przyjazny środowisku. W czasie pracy takiej małej elektrociepłowni powstają prąd i ciepło odbierane przez inteligentny system dystrybucji ciepła. W ten sposób do minimum ograniczane są straty energii oraz wzrasta niezależność od dostawców energii, a dzięki temu następuje redukcja kosztów. Korzyści ekonomiczne i środowiskowe są wymierne, ponieważ wzrasta produktywność energii i surowców energetycznych, a zmniejsza się emisja zanieczyszczeń.

Należy wspomnieć również o rozwoju mikroinstalacji, czyli instalacji odnawialnego źródła energii o mocy do 40 kWp. Najczęściej wykorzystuje się w nich energię słońca (moduły fotowoltaiczne, baterie słoneczne i kolektory słoneczne), ale buduje się także małe siłownie wiatrowe, wodne oraz ujęcia geotermalne.

Można wskazać dwa główne sposoby zmniejszenia zużycia energii cieplnej w budownictwie: minimalizowanie zapotrzebowania na ciepło do celów ogrzewczych oraz modernizację systemów grzewczych i źródeł ciepła. Obecnie oferowanych jest na rynku wiele nowoczesnych źródeł ciepła. Po pierwsze - kotły o wysokiej sprawności, tzw. kondensacyjne. Kolejne, rekuperatory central wentylacyjnych, to źródła ciepła, w których ciepło odpadowe w wentylacji i klimatyzacji pozwala na znaczne obniżenie mocy zainstalowanej w tym źródle. Stosowane są także kolektory słoneczne - źródła przeznaczone głównie do przygotowania ciepłej wody użytkowej lub współpracujące z innymi źródłami (np. pompami ciepła). 
Należy także wymienić kotły spalające biomasę w postaci granulatu (peletów) lub biomasę nieprzetworzoną (np. słomę), a także kotły spalające biogaz odzyskiwany na wysypiskach śmieci lub w oczyszczalniach ścieków. Jako nowoczesne źródło ciepła może być także wykorzystane pasywne ogrzewanie słoneczne.

Na szczególną jednak uwagę zasługują pompy ciepła, które są urządzeniami pracującymi w oparciu o układy termodynamiczne. Pozwalają na odzyskiwanie ciepła z układów zewnętrznych i przekazanie go do obiegu wewnętrznego. Jest to więc instalacja, która dzięki odwróconemu kierunkowi przepływu ciepła dostarcza je do domu. Ze względu na źródło ciepła pompy dzielimy na: powietrzne, gruntowe, powietrzne wylotowe oraz wodne pompy ciepła. Koszt budowy takiej instalacji jest stosunkowo niski na przykład w porównaniu z instalacją gruntową, ale ta z kolei wyróżnia się wyższą efektywnością. Przy montowaniu instalacji pobierającej ciepło z wody należy wykonać odwierty pionowe, jeśli zaś ciepło pobierane jest z ziemi, korzystniejszym rozwiązaniem są kolektory poziome.

Można stwierdzić, że obecnie stosowane nowoczesne źródła ciepła do celów grzewczych to urządzenia o wysokiej sprawności, dużej niezawodności technicznej, minimalnym oddziaływaniu na środowisko naturalne oraz niskich kosztach eksploatacji. Niestety wciąż są one wykorzystywane w zbyt małym zakresie, głównie z powodu wysokiego kosztu ich zakupu i montażu.

\section{Literatura}

Anisimow S. i in. (red.), Nowoczesne rozwiązania w inżynierii i ochronie środowiska, t. 1, Wydawnictwo Politechniki Wrocławskiej, Wrocław 2011.

Berger R., Zielony wzrost, zielony zysk. Jak zielona rewolucja stymuluje gospodarkę, Warszawa 2011.

Energia ze źródeł odnawialnych w 2013 r., GUS, Departament Produkcji, Warszawa 2014.

Energia 2015, GUS, Departament Produkcji, Warszawa 2015.

Kucowski J., Laudyn D., Przekwas M., Energetyka a ochrona środowiska, WNT, Warszawa 1997.

Psota Z., Alternatywna Polityka Energetyczna Polski do 2030 roku - Raport techniczno-metodologiczny, Instytut na rzecz Ekorozwoju, Warszawa 2009.

Strategia Bezpieczeństwo Energetyczne i Środowisko - perspektywa do 2020, Uchwała nr 58 Rady Ministrów z dn. 15.04.2014 r., (Dz.Urz. RP z dn. 16.06.2014 r., poz. 469). 
Stryczewska D., Technologie energii odnawialnej, Komitet Inżynierii Środowiska PAN, Warszawa 2011.

Szyjko T. (red.), Inżynieria środowiska: wybrane zagadnienia, Wydawnictwo MM, Warszawa 2012.

Urbaniak A., Zakrzewski P., Inteligentne systemy w inżynierii i ochronie środowiska, Wydawnictwo PZITS, Oddział Wielkopolski, Poznań 2007. http://np2050.pl.

http://orka.sejm.gov.pl/WydBAS.nsf/0/5E12A70DFB559604C1257A2A0045AB9B/\$file/Strony\%20odStudiaBAS\%2829\%29_I-6.pdf.

http://cte.fea.pl/.

http://www.zgazowaniewegla.agh.edu.pl.

http://www.argoxee.com.pl. 


\section{Spis rysunków}

Rys. 3.1. Ogólny podział technik membranowych w zależności od wielkości cząstek substancji separowanych

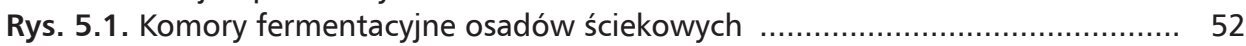

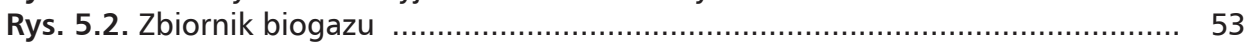

Rys. 5.3. Schemat przykładowego wykorzystania biogazu .............................. 54

Rys. 5.4. Widok ogólny GOŚK w Łodzi ...................................................... 59

Rys. 9.1. Schemat ciągu technologicznego służącego do uzdatniania wody pitnej ... 99

Rys. 9.2. Schemat działania filtra pospiesznego ............................................... 101

Rys. 9.3. Schemat działania osadnika wstępnego usuwającego zawiesiny metodą sedymentacji ................................................................................... 102

Rys. 10.1. Podział układów wodociągowych ze względu na ilość zastosowanych stref

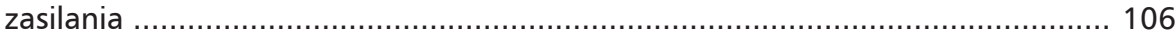

Rys. 10.2. Schemat przykładowego pełnego układu wodociągowego .................... 107

Rys. 10.3. Schemat przykładowego systemu kanalizacji ciśnieniowej ..................... 112

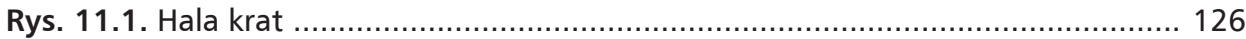

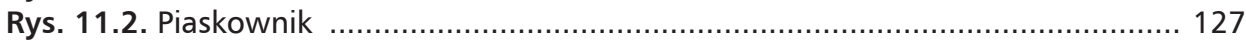

Rys. 11.3. Osadnik wtórny ................................................................... 128

Rys. 11.4. Komora biologiczna osadu czynnego z systemem napowietrzającym ...... 131

Rys. 11.5. Przykładowy schemat technologiczny pełnego układu oczyszczania ścieków z wykorzystaniem osadu czynnego .................................................... 131

Rys. 11.6. Fragment osadnika wtórnego radialnego oraz złoża biologiczne ............. 132

Rys. 11.7. Przykładowy schemat technologiczny oczyszczalni o zwiększonej efektyw-

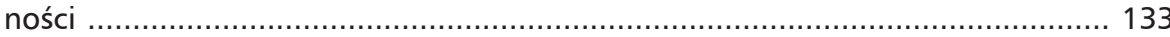

Rys. 11.8. Oczyszczalnia roślinna z filtrem trzcinowym jako trzeci stopień oczyszcza-

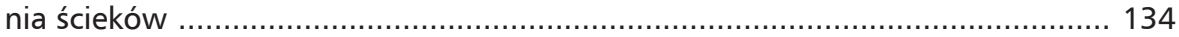

Rys. 11.9. Instalacja odwadniania osadów ściekowych .................................... 138

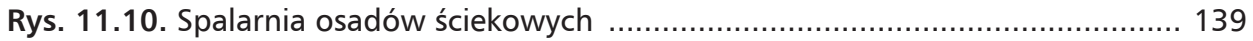

Rys. 11.11. Postępowanie z osadami z komunalnych oczyszczalni ścieków w Polsce 140 


\section{Spis tabel}

Tabela 7.1. Liczba urządzeń chroniących atmosferę przed emisją zanieczyszczeń zainstalowanych w kotłowniach w Polsce w latach 2012-2014 (w szt.)

Tabela 8.1. Zagospodarowanie odpadów w Polsce w latach 2012-2014 (w tys. ton) .. 92

Tabela 8.2. Odgazowywanie składowisk kontrolowanych w Polsce w latach 2012-2014 (w szt.) ........................................................................... 93

Tabela 10.1. Urządzenia wodociągowe w Polsce w latach 2005, 2010, 2013-2014 ... 108

Tabela 10.2. Urządzenia kanalizacyjne w Polsce w latach 2005, 2010, 2013-2014 ... 113

Tabela 10.3. Gospodarka wodociągowo-kanalizacyjna w Polsce w latach 2005, 2010, 2013-2014

Tabela 11.1. Instalacje do gromadzenia nieczystości ciekłych w Polsce w latach 2012-2014 (w szt.)

Tabela 12.1. Porównanie pozyskania energii ze źródeł odnawialnych według nośników w krajach UE-28 oraz w Polsce w 2013 r. (w \%) 
Podręcznik zawiera bogaty i ciekawy przegląd zagadnień z szerokiego zakresu inżynierii środowiska, poczynając od technik membranowych po technologie środowiskowe, ekoinnowacje technologiczne, obiekty budowlane służące ochronie środowiska, ochronę powietrza, litosfery, rekultywację gleb, ujęcia wód i uzdatnianie wody, systemy wodociągowe i kanalizacyjne, ochronę wód i oczyszczania ścieków i kończąc na infrastrukturze energetycznej. Zaprezentowaną w sposób nowatorski tematykę można uznać za bardzo ważną w aktualnej sytuacji rozwoju inżynierii środowiska, w zmieniających się warunkach klimatycznych i społeczno-gospodarczych.

Jako podręcznik dydaktyczny książka jest wartościowym źródłem wiedzy i inspiracji dla studentów różnych kierunków kształcenia: ochrona środowiska, inżynieria środowiska, ekonomia ochrony środowiska, gospodarka przestrzenna, architektura krajobrazu i innych. Zainteresowani podręcznikiem mogą być również inżynierowie z szerokiego zakresu inżynierii środowiska, pracujący nad planowaniem przestrzennym, projektowaniem i realizacją inwestycji przyjaznych środowisku naturalnemu. Podręcznik wypełnia także lukę, jaka występuje zarówno w szkoleniu kadr, jak i doskonaleniu zawodowym projektantów i samorządowców w zakresie wdrażania do praktyki gospodarczej innowacyjnych rozwiązań wykorzystujących technologie środowiskowe.

Z recenzji prof. dr. hab. inż. Jerzego Jeznacha, Szkoła Główna Gospodarstwa Wiejskiego w Warszawie

\section{norway grants}

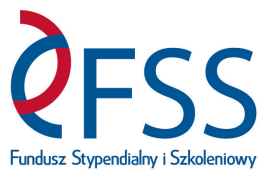

Projekt „Utworzenie nowych interdyscyplinarnych programów kształcenia w zakresie ekonomii ochrony środowiska (w języku polskim i angielskim) w Uniwersytecie Łódzkim". Celem projektu jest zwiększenie wiedzy i świadomości polskich i zagranicznych studentów, wykładowców, absolwentów UŁ z zakresu zrównoważonego rozwoju, ekologii, biznesu międzynarodowego i finansów.

Publikacja jest współfinansowana ze środków funduszy norweskich i krajowych. Kwota dofinansowania projektu: 533083 PLN

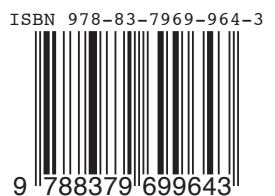

